Clinical consideration of some rare emergency thoracic cases in pediatric surgery

ANNA RIETH M.D.

PhD Thesis

Szeged

2020 


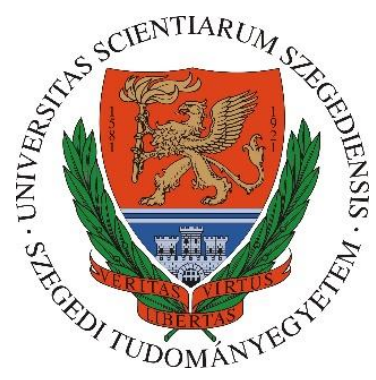

\section{UNIVERSITY OF SZEGED FACULTY OF MEDICINE}

DOCTORAL SCHOOL OF CLINICAL MEDICINE

Department of Pediatrics

AND DEPARTMENT OF SURGERY

Head of Doctoral School

Prof. Dr. György Lázár, Ph.D., D.Sc.

\section{SUPERVISOR}

József Furák M.D., Ph.D., med.habil. 


\section{List of full papers related to the subject of the thesis}

I. Rieth A., Kovács T., Novák Z., Kapus K., Ottlakán A., Németh T., Furák J.

Surgical treatment of awn aspiration causing bronchopleural fistula and bronchiectasis: case reports. BMC Pediatr. 2019 Oct 22;19(1):368.

IF: 1,909

II. Rieth A., Varga E., Kovács T., Ottlakán A., Németh T., Furák J.

Contemporary management strategies of blunt tracheobronchial injuries. Injury. doi:10.1016/j.injury.2020.07.026

IF: $\mathbf{2 , 1 0 6}$

III. Rieth A., Ottlakán A., Kovács T., Balogh B, Furák J.

The role of an overinflated endotracheal tube in the diagnosis of tracheal injuries. ORV HETIL. 2020;161(25):1063-8.

IF: 0,497 


\section{List of abstracts related to the subject of the thesis}

\section{Rieth A., Etlinger P., Kovács T., Furák J.}

A rare case of laryngotracheal injury in a blunt trauma caused by elevated seat-belt

Gyermektraumatológiai Szekció XXVI. Vándorgyülés, Pécs, 2019.10.03-05.

\section{Rieth A., Novák Z., Ottlakán A., Kovács T., Furák J.}

Rare cases of awn aspiration causing bronchopleural fistula and bronchiectasis

20th EUPSA, Belgrade, 2019.06.12-15.

\section{Rieth A., Novák Z., Kovács T., Furák J.}

Toklász aspiráció okozta bronchopleuralis fistula és bronchiectasia - két ritka gyeremekkori eset bemutatása

Magyar Gyermekaneszteziológiai és Intenzív Terápiás Társaság és a Magyar Gyermeksebész Társaság közös Kongresszusa, Visegrád, 2019.04.25-27. 


\section{CONTENTS}

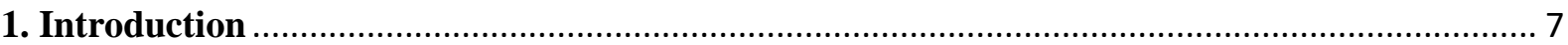

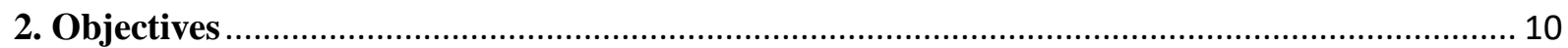

3.1. A special type of foreign body aspiration - inhalation of grass head ................................... 11

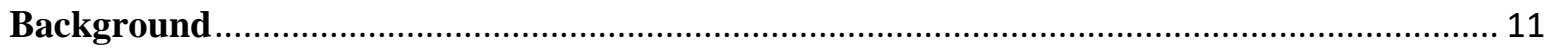

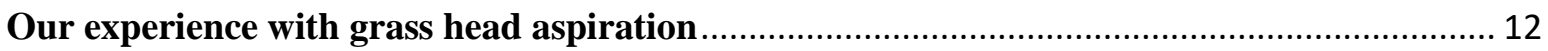

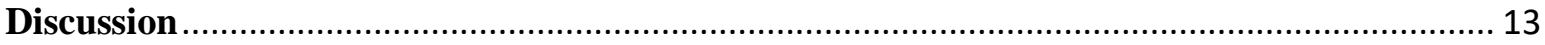

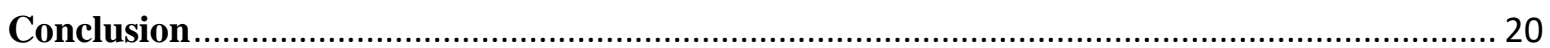

3.2. Contemporary diagnostic and treatment options of tracheobronchial injuries .................... 21

Important characteristics of tracheobronchial injuries.......................................................... 21

Experience with unique cases of tracheobronchial injuries in our practice ............................ 21

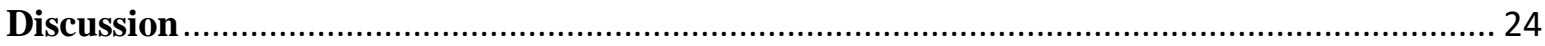

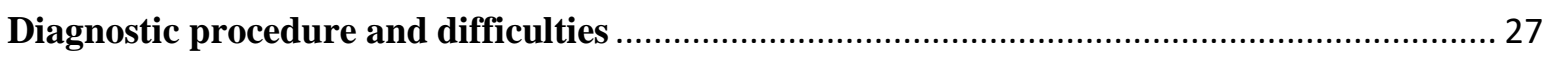

Modern treatment options of tracheobronchial injuries ........................................................ 33

Summary of the most important current treatment strategies and process .............................. 39

3.3. The role of overinflated endotracheal tube cuff in the diagnosis of tracheal injuries............ 41

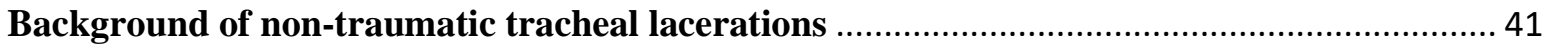

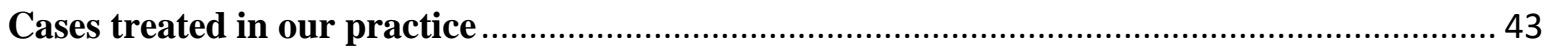

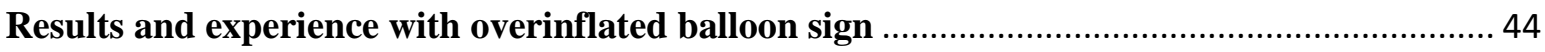

Summary of the possibilities of overinflated balloon-sign ..................................................... 46

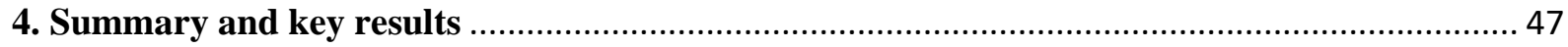

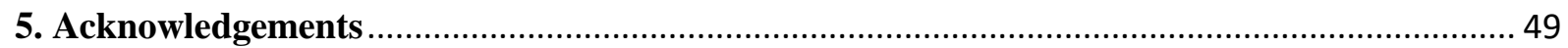

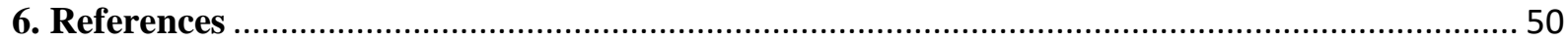




\author{
ABBREVIATIONS \\ ATLS - Advanced Trauma Life Support \\ CRP - C-reactive protein \\ CT - Computed Tomography \\ CXR - Chest X-Ray \\ DLT - Double-Lumen Endotracheal Tube \\ ECMO - Extracorporeal Membrane Oxygenation \\ eFAST - Extended Focused Assessment with Sonography in Trauma \\ ETT - Endotracheal Tube \\ FB - Foreign Body \\ GCS - Glasgow Coma Scale \\ MDCT - Multi-slice detector computed tomography \\ RSI - Rapid Sequence Intubation \\ SEMS - Self-Expanding Metallic Stent \\ TEF - Tracheoesophageal Fistula \\ TBI - Tracheobronchial Injury
}




\section{Introduction}

Emergency pediatric thoracic surgery involves widespread forms of thoracic diseases, including congenital malformations such as pulmonary sequestration or lobar emphysema, acquired diseases such as pneumonia, or traumatic injuries such as airway trauma. During our research we studied rare pediatric thoracic disorders having unacquainted official management protocol due to the lack of adequate patient number, thus proper experience. Our aim was to provide comprehensive coverage of diagnostic challenges and the most up-to-date treatment strategies. The main course of the thesis includes discussion of a special type of aspiration, and blunt tracheobronchial injuries.

The first main topic of the thesis deals with a special type of foreign body (FB) aspiration. FB inhalation is a well-known entity, which remains a leading cause of accidental death among children, especially among those younger than 1 year (1). In general, more than $70 \%$ of involved children are less than 3 years old (1). Due to this widely known phenomenon, plenty of protocols and algorithms are available in the management of FB aspiration based on similar strategies (1-5).

The main concepts of treatment are the following: 1) positive history of FB aspiration 2) changes in physical status 3) or in radiological appearance. However the diagnosis can even be challenging during simple FB aspiration, as history is often vague, and in addition, specific clinical symptoms and radiological signs are lacking. Fidkowski et al. (6) demonstrated that witnessed history of FB aspiration reported by patients can be as low as $58.3 \%$ for sensitivity and $32.1 \%$ for specificity. Physical examination can reveal the classic triad of symptoms, such as sudden onset of cough, diminished breath sounds, and wheezing. However $60 \%$ of patients lack such symptoms (1).

A posteroanterior CXR is the preferred radiological modality, supplemented by airway fluroscopy in some institutions (7). Nevertheless, X-ray fidings also bear low sensitivity and specificity (6).

In conclusion, the absence of specific physical or radiological findings do not exclude the presence of an airway FB, thus treatment decision is often difficult and high level of suspicion is required. Most protocols recommend that two of three main points (history of aspiration, physical-, or radiological changes) should be present to indicate 
bronchoscopy (2-4). In these cases rigid bronchoscopic should be carried out to definitely exclude airway foreign body, and to potentially remove FB.

It is often difficult to diagnose non-specific aspirations, moreover, there are some special forms of foreign bodies, when general protocols are not advised. One of these special types is grass head aspiration, which has specific symptoms, features, and thus requires special management strategy. Literature data is short on grass head aspiration among children, however we present our experience and an feasible management algorithm. Our aim was to emphasize the importance the condition, and to highlight the need for minimal resection during surgical treatment.

The other main topic of the thesis discusses blunt tracheobronchial injuries. Although thoracic trauma is considered a rare problem among the pediatric population (10\% of all traumas (8)), its incidence is still increasing due to the improvement of motorization and high velocity road traffic accidents. Mortality of isolated thoracic trauma in children is estimated to be between 1-5\% $(9,10)$, however additional injuries of any other body region may increase it up to $29 \%$, while combined with head injury, the incidence of fatal outcomes reach $40-70 \%$ (10).

The majority of infant chest traumas can be successfully managed conservatively, involvment of intensive care unit is rarely needed, and only $10 \%$ of patients require invasive, or surgical treatment (10).

Children have peculiar anatomical features compared to adults, strongly influencing diagnosis, prognostic outcome, or successful conservative treatment options. Numerous important differences must be noted. The most significant difference compared with adults are the following: 1) children have less protective layer such as fat, muscle and connective tissue covering the organs; 2) the flexible, cartilaginous chest is able to transfer energy to intrathoracic organs without fracture or any visible sign of severe trauma; 3) the mobile mediastinum can be easily shifted by severe and rapidly progressing tension pneumothorax; 4) children have a higher metabolic rate, greater oxigen requirement, and hypoxaemia tends to develop much faster, than in adults; 5) cardiac output depends on cardiac rhythm and preload, which is rapidly decreases during dislocated mediastinal trauma; 6) multiple organs can be involved due to the 
impact of the same amount of energy on a smaller body; 7) there is rarely any additional chronic disease, hence excellent tendency for recovery is expected $(9,10,11)$. Therefore, due to their unique pathophysiology pediatric trauma patients deserve special considerations in thoracic management strategies.

The aforementioned characteristics result in higher incidence of pulmonary contusion, pneumothorax or rib fracture, while the heart, great vessels, airway, diaphragm or oesophagus are rarely involved (10). Tracheobronchial injury (TBI) is noted as an exceptionally uncommon condition in the adult population, however the incidence among children is even less lower, as its rate is estimated to be $0.7-2.8 \%$ (12). It can potentially become a life-threatening condition, and the majority of these patients $(30-80 \%)$ still die at the scene of the accident $(13,14)$. Early diagnosis is essential in reaching improved patient survival. Avoiding airway obstruction and early, successful surgical management are vital for a successful outcome. The lack of typical clinical symptoms and diverse radiological appearance often lead to delayed diagnosis.

Due to the rare occurrence of TBI, limited experience and the low number of patients, the management of TBI remains highly diversified in different institutions, with specific guideline is still lacking $(15,16)$. Our aim was to collect current up-to-date information and recommendations on blunt tracheobronchial injuries of the neck and thorax. Our further purpose was to clarify the drawbacks of diagnostic challenge, and to construct a feasible, easily applicable management alogrithm. Furthermore, through our own surgical experience, we would like to highlight the importance of early diagnosis and prompt management. While decisions are often based on clinical suspicion, we would like to present an uncommon, though direct and special radiological sign of TBI, which could help clinicians in reaching improved diagnosis. The overinflated endotracheal tube (ETT) cuff is an easily detectable sign of complete tracheal wall rupture. It can be confirmed even on a chest X-ray (CXR), thus early targeted fiberoscopy can be carried out. 


\section{Objectives}

The need for urgent pediatric thoracic surgery is relatively rare, thus only limited number of patients and experience are available on the investigated topics. The thesis deals with two main topics: 1) a special type of grass head aspiration; and 2) contemporary management strategies in blunt tracheobronchial injuries and the importance of early diagnosis due to overinflated endotracheal tube cuff.

Although these are special and rare childhood conditions, no proper guideline in surgical treatment is available. Our aim was to investigate recent studies, and to provide a broad review of literature. Diagnostic difficulties, treatment options and clinical decision-making were analysed for each disease, with the completion of our own practice.

Addressed questions summarized:

I. to emphasize the difficulties of inflorescence aspiration, and reveal its most important features (Study 1)

II. to define recommended treatment algorithm in the management of grass head aspiration (Study 1)

III. to review best diagnostic and current treatment options for blunt airway injuries (Study 2)

IV. to define the role and practical possibilities of the underestimated sign of overinflated ETT cuff in the diagnosis of tracheal injuries (Study 3) 


\subsection{A special type of foreign body aspiration - inhalation of grass head}

\section{Background}

Aspiration of FB is a frequent and well-known problem, especially in case of children. They tend to take toys, food or organic substances into their mouth and keep them inside while playing or running. Thus, when they stumble or fall, they easily inhale them. There are some special types of FB aspiration requiring attention, such as grass head aspiration. Its inhalation is extremely rare, and requires special management. The difference between aspiration of grass heads or other FB is due to shape. A smooth object overlies the bronchial mucosa, while grass heads with several spikes can transfer towards the periphery of the lung (17-19). Our intention was to describe their special characteristics through our own two recent cases. One patient had pleuropneumonia and the other bronchiectasis, caused by the bristly head of barley grass. Based on our experience and the revised literature, we recommend a management strategy for enhanced diagnosis.

Grasses (Poaceae) are a botanical family of flowering plants (inflorescences) found on almost every field or along roads. Hordeum morinum or the so-called barley grass is one of the most common member of this plant family, being indigenous to Europe, among other continents (Figure 1.). Their heads bear several spikes and bristles, that are responsible for one-way selfpropulsion inside the respiratory tract, and are thus responsible for the atypical symptoms and outcomes. Each coughing and respiratory action make them migrate towards the periphery of the lung. They get deeper and deeper until they reach the chest wall, and are even able to penetrate to the outside. 


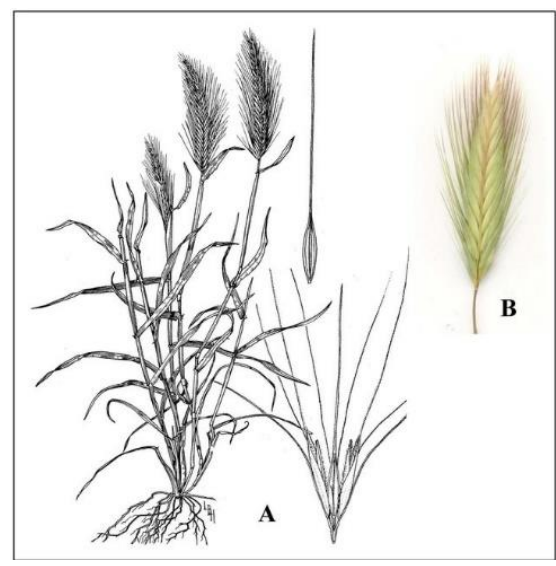

Figure 1. Hordeum morinum: “(A) Plant, spikelet triplet, and floret with long bristle; (B) spikelet” (Image: Felger et al. (20))

\section{Our experience with grass head aspiration}

Case 1

A 4-year-old boy was transferred to our emergency department with a 7-day long history of grass head aspiration. Chest X-ray, esophagogram and direct laryngoscopy were negative. Despite initial antibiotic therapy, fever developed after 6 days with elevated C-reactive protein (CRP) (38 mg/L). Repeated chest radiography confirmed atelectasis and pneumonia of the right lower lobe. During rigid bronchoscopy no foreign body was found. On the ninth day after aspiration, CRP elevated to $99 \mathrm{mg} / \mathrm{L}$ and symptoms did not improve. Due to physiotherapy, bronchodilators, expectorants, inhalation and change in antibiotic therapy, the patient was discharged after one month with normal blood work and decreased signs of pleuropneumonia on CXR.

During the next 5 months conservative treatment was ineffective for recurring symptoms. Six months after the foreign body aspiration, chest computed tomography (CT) revealed bronchiectasis in segments 9 and 10 of the right lung. Repeated bronchoscopic was performed, and purulent secretion with fragments of grass head were removed from the right lower lobe. Nine months after the accident, control bronchoscopy showed persistent signs of inflammation in the right lower bronchi with huge amounts of secretion. Due to recurrent symptoms and chronic pneumonia, surgery was performed. During posterolateral thoracotomy, severe adhesions were detected between the chest wall and the right middle- and lower lobe, with inflammed hilar lymph nodes. Because of the macroscopically abnormal appearance and chronic inflammation of the complete right lower lobe, lobectomy was carried out.

Histopathology confirmed chronic inflammation and bronchiectasis caused by a grass head blocking the bronchial lumen. The postoperative period was uneventful, and the fully recovered, asymptomatic child was discharged on the $13^{\text {th }}$ postoperative day. 
Case 2

A 9-year-old boy was referred to our institution with a 6-day long history of grass head aspiration. At the moment of inhalation, coughing and vomiting were the main symptoms. Fragments of the grass head were found in his vomit and stool. Two days after the aspiration, fever and chest pain developed, however no changes were detected on chest X-ray. Despite antibiotic therapy, intensity of chest pain increased. Leucocytosis $\left(14.76 \times 10^{6} / \mu \mathrm{L}\right)$ with neutrophil predominance was seen in blood count, with highly elevated CRP $(99.4 \mathrm{mg} / \mathrm{L})$. After six days a repeated CXR showed right sided infiltration and pleural effusion. Rigid bronchoscopy under general anaesthesia was performed, but no endobronchial pathology was detected. Bronchial fluid was negative for bacteria. Due to conservative treatment, symptoms and blood markers improved after sixteen days of aspiration (white blood cell count decreased: $10.000 \times 10^{6} / \mu \mathrm{L}$ without left shift, and decreased CRP: $19.77 \mathrm{mg} / \mathrm{L}$ ). Rutin chest ultrasound and X-ray showed regression of pulmonary inflammation. 32 days after the accident, a round shaped lesion was detected at the site of the right lower lobe, suggesting possible abscess formation. CT showed a $41 \times 20 \mathrm{~mm}$ area with decreased air content in the S6 segment of the right lung, with pleural involvement.

According to the history of floret inhalation, localized lung abscess, pleural effusion, and the course of grass head aspiration resulting in potentially life-threatening complications, surgery was decided. During posterolateral thoracotomy focal adhesions were found between the right lower lobe and the diaphragm. A 4-cm-long piece of barley grass was extracted from the pleura, and an abscess wall around segment S6 was found. Due to localized inflammation and possible residual foreign body segmentectomy was performed. Symptoms were relieved postoperatively, while follow-up CXR showed no signs of the former abscess. The child was discharged on the $8^{\text {th }}$ postoperative day. Histology confirmed the presence of chronic granulomatous inflammation caused by barley grass aspiration.

\section{Discussion}

Historically, in 1952 Chevalier Jackson (17) was the first, to cathegorize grass heads, and discuss their characteristics. Based on the structure of the head and behaviour of the plants, inflorescences were classified into two different types. A small proportion was the so-called "lodging" or "non-extrusive" type, which tends to remain in the respiratory tract, resulting in obstruction or recurrent pneumonitis. A typical member of this type is the timothy grass (Phleum pratense), common in North-America. This kind of grass is able to remain in the respiratory tract even after months, and can be eliminated through bronchoscopy (21). However, the majority, called "extrusive" type has the power of changing location, while retrograde movement is blocked by its sharp spikelets. This type of inflorescence rapidly 
transfers deep beyond the reach of the bronchoscope, which leads to diagnostic failures. They keep migrating to the periphery of the lung until finally extruding through the chest wall (2225). The first reported case originates from 1662, which was both the first case of a grass head aspiration and the first case of spontaneous percutaneous elimination (26). Since then, this feature has been confirmed by several authors (23-25,27). Godfrey (18) and Woolley (19) defined the physical differences between the two types of florets. The spikelets on the head of the non-extrusive type are soft and the arrangement is tight (for instance timothy grass), which lets the grass stay in the bronchus. On the other hand, members of the extrusive type (for example barley grass) have firm spikes with acute angles, which help them in self-propulsion $(25,28)$. It is interesting to note, that there is few literature data on grass heads being successfully coughed up $(27,29)$. This is due to the direction of the head (Figure 2.), however these cases are extremely rare, and is not the typical behaviour of grass heads as FB.
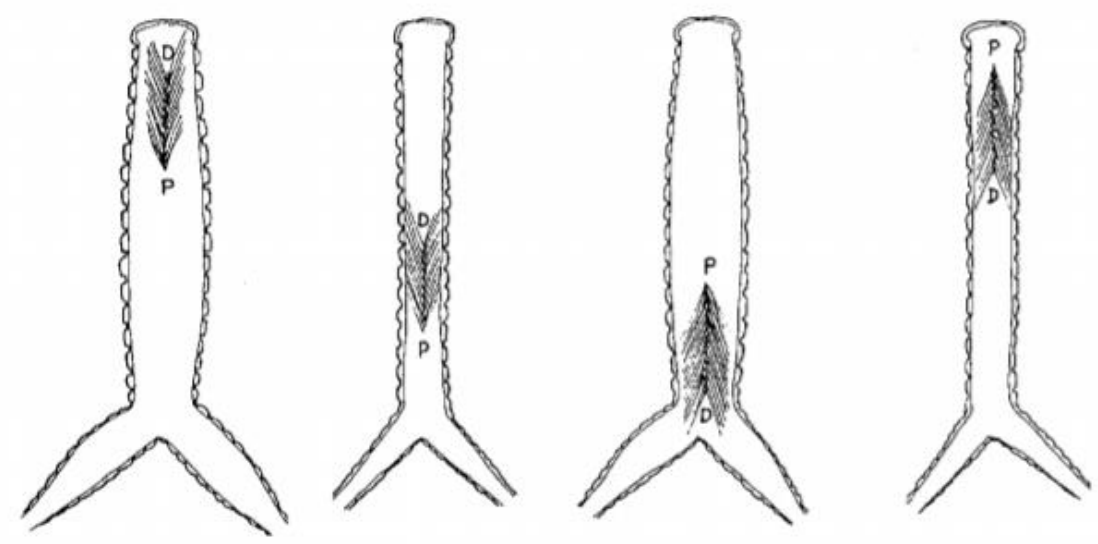

Figure 2. Explanation of possible floret elimination with coughing: if the grass head enters with the proximal part $(\mathrm{P})$, every cough reflex will transport it deeper. But if the proximal end is toward the outside, coughing may rarely be effective in elimination. (Image: Dindar et al. (25))

At the moment of aspiration usually only mild symptoms dominate, such as coughing, choking, vomiting or wheezing, however, as the grass head travels deeper these initial symptoms mostly diminish. The following period is characterized by asymptomatic or continously improving physical status. As the grass head easily migrates beyond the reach of the bronchoscope, even immediate examination is mostly negative. These results may create a false sense of security both in physicians and parents. However, the presence of a bronchial grass head can not be excluded despite negative clinical results or improved inflammatory 
markers. Nevertheless serious complications may develop after a few days due to migration onto the periphery, such as aspiration pneumonia, bronchocutaneous fistula, bronchiectasis and other, even life-threatening complications.

According to literature on floret aspiration in children, the most frequently reported complications caused by grass head migration were: recurrent haemoptysis (22,30-32), bronchiectasis $(19,22,27-29,31,33), \quad$ pneumonitis $(18,19,21,23,27,31,33,34)$, bronchopleurocutaneous fistula and extrusion of grass head through the chest wall $(18,23-$ 25,27,35-37), while tension pneumothorax (38-40), pleural effusion, and empyema were also frequently mentioned. Osteomyelitis of the rib (22), consequently developing brain abscess or coexisting acute abdomen $(25,34)$ were described in isolated cases. Pneumonitis during summer should be an alarming sign of possible grass head aspiration, as inflorescences bloom seasonally (19).

Aspiration of grass head is a rare phenomenon, and only few cases were reported in children. A study by Clery et al. (28) was the last research to contain a comprehensive literature review until 1959, describing 65 children suffering from grass head aspiration. With his report, a total of 133 infant cases (including our two case) were found in the uptodate literature. Nevertheless, most physicians have limited familiarity with this entity, as it is usually once in a lifetime experience, thus still presenting a lack of management recommendations. With our two cases and review of the literature, we suggest diagnostic and management algorithms to reduce respiratory damage and prevent severe complications.

The diagnosis of aspirated grass heads is difficult due to the abovementioned symptoms, mostly improving physical status and negative bronchoscopy. Nevertheless, literary data is consistent, that immediate bronchoscopy should be performed in all cases with suspected grass inflorescence aspiration (21-23,27). However, positive bronchoscopy, or endoscopic removal may only be accomplished prior to deep migration, and in some cases of the lodging type (21). It is well-known, that aspirated FB (such as grass heads) is most likely to be aspirated into the right lower bronchial tree due to its anatomical structure, hence more emphasise should be placed on the right side during bronchoscopy. According to the revised literature, right-sided dominance has also been found in 42 cases, compared with 11 left-sided cases. Inhalation into the right lower lobe occurred during both of our cases. 
Among the 133 children, 95 probably aspirated an extrusive grass head, compared to 26 non-extrusive type inhalations (we have no valid information about 12 children) (Table 1.). Endoscopic removal was successful in 39 cases (32,2\%), including 12 laryngoscopy during the early phase. Ammari et al. (39) reported 12 interesting cases about barley grass (from extrusive type), as they were able to extract them before deep migration. Of the 133 children, 35 required surgical management $(28,9 \%)$, while 40 grass heads $(33,1 \%)$ protruded spontaneously through the chest wall. It is interesting, that 5 spontaneous expectorations $(4,1 \%)$ were detected, and 2 children (1,7\%) died due to 1$)$ abscess in the liver and lung; and 2) widespread empyema and bronchopneumonia (28).

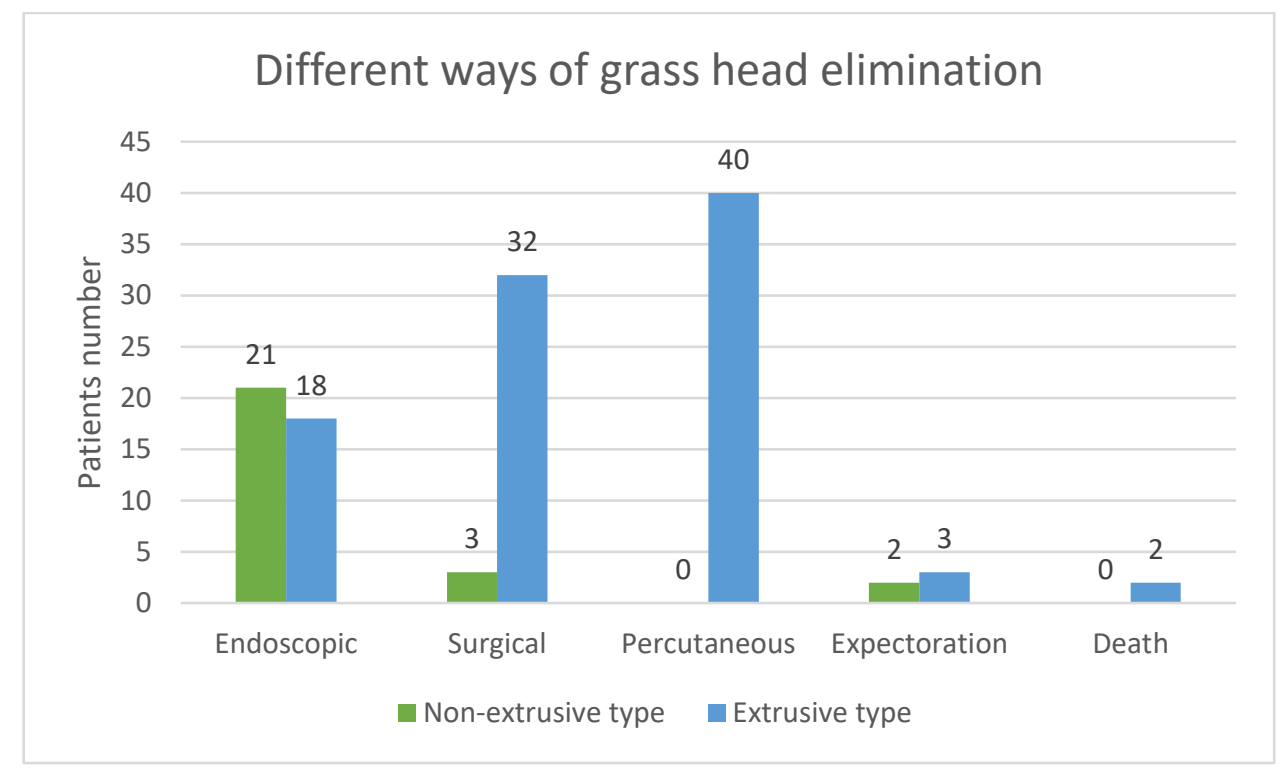

Table 1. Summarized patient number in different outcomes both in the extrusive and the lodging type

According to rapid propulsion, the presence of a bronchial floret can not be excluded after negative bronchoscopic result or improved inflammatory markers, thus an asymptomatic child should be followed up thoroughly to recognise exacerbation in time. It is strongly recommended to perform regular chest ultrasound or CXR to recognise signs of early inflammation and lateonset severe complications. In case these examinations reveal any potential inflammation site, CT can be a valuable diagnostic tool to localise and identify the foreign body, or to confirm complications. Despite the fact, that our two cases had improved laboratory markers and symptoms, CT showed bronchiectasis in Case 1 after six months, while abscess formation was 
revealed in Case 2 after 32 days (Figure 3.). These results suggested the presence of grass head in the respiratory tract.

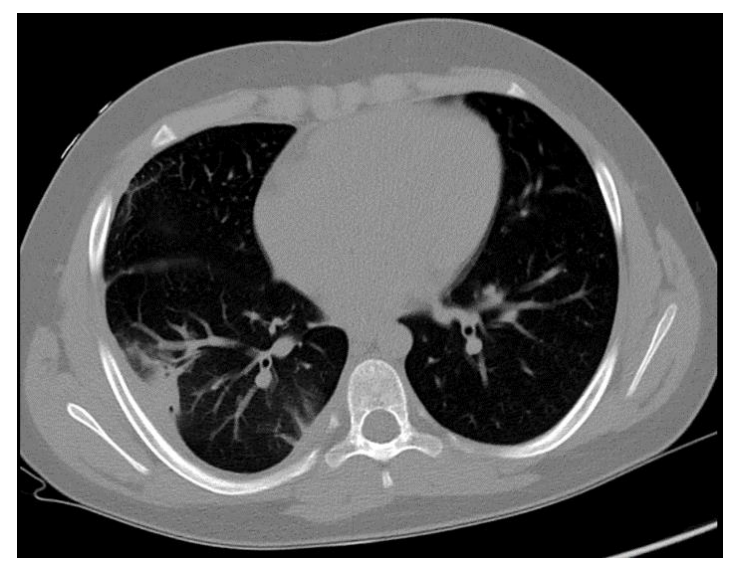

Figure 3. Computed tomography confirming pleuropneumonia in Case 2

Courtesy of Affidea Ltd.

There is no exact protocol in the literature on "wait-and-see" or surgery. The majority of cases showed, that delayed diagnosis may lead to serious, irreversible conditions (such as residual bronchiectasis, or bronchopleurocutaneous fistula), or potentially life-endangering complications. Despite the fact that inflammation may temporarily improve or vanish, we agree on early surgical exploration to prevent the aforementioned consequences. Surgery is opted when signs of localised inflammation are detected on CXR or CT.

In Table 2. we gathered the different outcomes of grass head aspiration based on previously reported cases, and collected time of elimination. The table reveals the fact, that even years can pass without serious complications, but on the other hand, spontaneous percutaneous elimination may develop after 2 weeks. It is also noteworthy, that Jewett et al. (33) and Basok et al. (29) both reported aspirations that involved both lower lobes, not only the affected one. While FB was found in one lobe, long-term inflammation spreaded to the other side, resulting in bilateral lobectomy in one case (29). Clery et al. (28) reported a case, successfully treated by bronchoscopic FB removal. However, 10 years after the accident the patient did require lobectomy due to residual bronchiectasis. 


\begin{tabular}{|c|c|c|c|c|c|c|}
\hline Author & $\begin{array}{c}\text { Gender } \\
\text { (Female/Male) }\end{array}$ & Age & Location & $\begin{array}{c}\text { Type of } \\
\text { elimination }\end{array}$ & $\begin{array}{c}\text { Time between } \\
\text { aspiration and } \\
\text { elimination }\end{array}$ & Complications \\
\hline \multirow[t]{2}{*}{ Nasr et al. (21) } & M & $1 \mathrm{y}$ & RLL & Bronchoscopy & $5 \mathrm{mo}$ & Pn. \\
\hline & M & $5 y$ & RLL & Bronchoscopy & $6 \mathrm{mo}$ & Pn. \\
\hline \multirow[t]{4}{*}{ Hilman et al. (27) } & M & $7 y$ & RLL & Lobectomy & $1 \mathrm{y}$ & $\mathrm{Br}$. \\
\hline & M & $13 \mathrm{y}$ & RLL & Expectoration & $2 \mathrm{mo}$ & Pn. \\
\hline & M & $14 \mathrm{y}$ & RLL & Lobectomy & $6 \mathrm{mo}$ & $\mathrm{Pn}$ \\
\hline & M & $14 \mathrm{y}$ & LLL & Percutan & $6 \mathrm{mo}$ & Pn., Bpcf. \\
\hline \multirow[t]{3}{*}{ Maayan et al. (22) } & M & $9 \mathrm{y}$ & RLL & Lobectomy & $7 y$ & Haem., Br. \\
\hline & M & $7 \mathrm{mo}$ & RLL & Percutan & 9 mo & $\begin{array}{c}\text { Ptx., Rib } \\
\text { osteomyelitis }\end{array}$ \\
\hline & M & $0,5 \mathrm{y}$ & RLL & Bronchoscopy & $10 \mathrm{mo}$ & Pn. Haem. \\
\hline Kanbur et al. (23) & M & $13 \mathrm{y}$ & RLL & Percutan & $5 \mathrm{mo}$ & Pn. \\
\hline Karagöz et al. (24) & M & $9 y$ & RLL & Percutan & 2 weeks & Bpcf. \\
\hline \multirow[t]{3}{*}{ Basok et al. (29) } & M & $8 \mathrm{y}$ & LLL & Expectoration & $4 y$ & Haem., Br. \\
\hline & M & $7 y$ & RLL & Pneumonectomy & $3 y$ & $\begin{array}{c}\text { Br. in total right } \\
\text { lung }\end{array}$ \\
\hline & $\mathrm{F}$ & $6 y$ & RLL & $\begin{array}{l}\text { Lobectomy } \\
\text { (bilat.) }\end{array}$ & $5 y$ & $\begin{array}{c}\text { Br. in both lower } \\
\text { lobe }\end{array}$ \\
\hline \multirow[t]{2}{*}{ Spencer et al. (34) } & $\mathrm{F}$ & $4 y$ & RLL & Bronchoscopy & $3 y$ & Pn. \\
\hline & M & $1,5 \mathrm{y}$ & RLL & Lobectomy & $3 \mathrm{mo}$ & Pn. \\
\hline \multirow[t]{2}{*}{ Choremis et al. (37) } & $\mathrm{F}$ & $3 y$ & LLL & Percutan & $2 \mathrm{mo}$ & Bpcf. \\
\hline & M & $2,5 \mathrm{y}$ & RLL & Percutan & 10 days & Bpcf. \\
\hline Cavens et al. (36) & M & $5 \mathrm{mo}$ & RLL & Percutan & $1,5 \mathrm{mo}$ & Bpcf. \\
\hline \multirow[t]{4}{*}{ Dudgeon et al. (31) } & M & $10 y$ & LLL & Lobectomy & $10 \mathrm{mo}$ & Haem., Atelectasis \\
\hline & M & $4 y$ & LLL & Lobectomy & $3 \mathrm{mo}$ & Pn., Br., Haem. \\
\hline & M & $1,5 \mathrm{y}$ & RLL & Lobectomy & $7 \mathrm{mo}$ & Pn. \\
\hline & $\mathrm{F}$ & $1,5 \mathrm{y}$ & RLL & Lobectomy & $8 \mathrm{mo}$ & Pn., Br. \\
\hline \multirow[t]{2}{*}{ Godfrey et al. (18) } & M & $9 y$ & RLL & Lobectomy & 4 mo & Pn. \\
\hline & $\mathrm{F}$ & $16 \mathrm{mo}$ & RLL & Percutan & $1,5 \mathrm{mo}$ & Bpcf. \\
\hline Harries et al. (35) & $\mathrm{F}$ & $22 \mathrm{mo}$ & $\begin{array}{l}\text { Right } \\
\text { side }\end{array}$ & Percutan & 4 mo & Bpcf. \\
\hline \multirow[t]{4}{*}{ Jewett et al. (33) } & $\mathrm{F}$ & $7 y$ & LLL & Lobectomy & $6 \mathrm{mo}$ & $\mathrm{Br}$ \\
\hline & M & $1 \mathrm{y}$ & LLL & Bronchoscopy & $1,5 \mathrm{mo}$ & $\begin{array}{c}\text { Br., Pn. in both } \\
\text { lower lobe }\end{array}$ \\
\hline & M & $20 \mathrm{mo}$ & RLL & Lobectomy & $5 \mathrm{mo}$ & Pn. \\
\hline & M & $2,5 \mathrm{y}$ & RLL & Lobectomy & $1 \mathrm{y}$ & Pn. \\
\hline Pattison et al. (30) & $\mathrm{F}$ & $17 \mathrm{y}$ & LLL & Wedge resection & $4 y$ & Haem. \\
\hline \multirow[t]{3}{*}{ Woolley et al. (19) } & M & $4 y$ & RLL & Bronchoscopy & $1 \mathrm{y}$ & $\mathrm{Br}$. \\
\hline & $\mathrm{F}$ & $18 \mathrm{mo}$ & RLL & Bronchoscopy & $3 \mathrm{mo}$ & Pn., Br. \\
\hline & M & $22 \mathrm{mo}$ & RLL & Lobectomy & $3 y$ & Pn. \\
\hline Diggory et al. (32) & $\mathrm{F}$ & $11 \mathrm{y}$ & RLL & Lobectomy & $4 \mathrm{y}$ & $\begin{array}{c}\text { Haem., Abscess in } \\
\text { lobe }\end{array}$ \\
\hline
\end{tabular}

Table 2. Collection of the main characteristics of aspirated cases, with emphasis on the type of elimination and elapsed time ( $\mathrm{y}$ - year, mo - month, RLL - right lower lobe, LLL - left lower lobe, RMB - right main bronchus, LMB - left main bronchus, Pn. - Pneumonitis, Ptx. - Pneumothorax, Br. - Bronchiectasis, Bpcf. Bronchopleurocutaneous fistula, Haem. - Haemoptysis) 
During our first case, lobectomy had to be carried out due to extensive pulmonary inflammation, while in case of the second patient, resection of the rigth S6 segment was performed due to localised inflammation (Figure 4,5). According to literature, lobectomy is the most preferred approach during surgical removal. However, in case of fast diagnosis or localized inflammation, segmentectomy should be considered as a tissue-saving option.

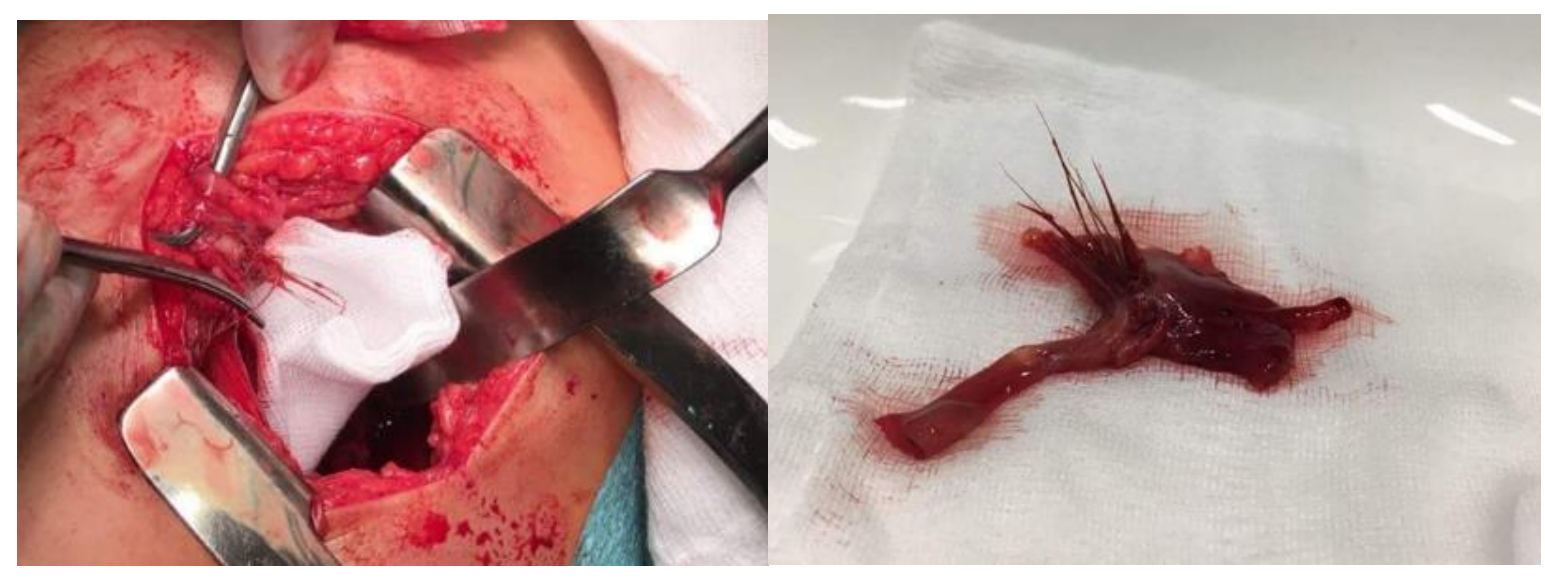

Figure 4. Intraoperative image of aspirated grass head in Case 2 - Courtesy of University of Szeged, Dep. of Surg.- Jozsef Furak M.D.
Figure 5. Removed grass head specimen in Case 2 showing several spikes, with an unidirectional migration towards the periphery - Courtesy of University of Szeged, Dep. of Surg.- Jozsef Furak M.D. 


\section{Conclusion}

We conclude that the diagnosis of grass head aspiration often leads to difficulties due to its special features. The presence of a bronchial grass head can not be excluded after negative bronchoscopy, or improved inflammatory markers, furthermore, an asymptomatic child should be followed up thoroughly to recognise sequalae in time. Regular diagnostic procedures (such as CXR, or chest ultrasound) should be carried out in order to localise early inflammation. Chest CT is valuable in identifying the position of the grass head. Surgical intervention is opted when the floret stays peripheral, with only localised inflammation, however should be performed before the appaerance of severe complications. In case the grass head is found at the site of a localized inflammation, anatomical segmentectomy with the removal of the affected bronchus may be preferred. In case of extended inflammation, or obscure conditions, lobectomy may be inevitable (Figure 6.).

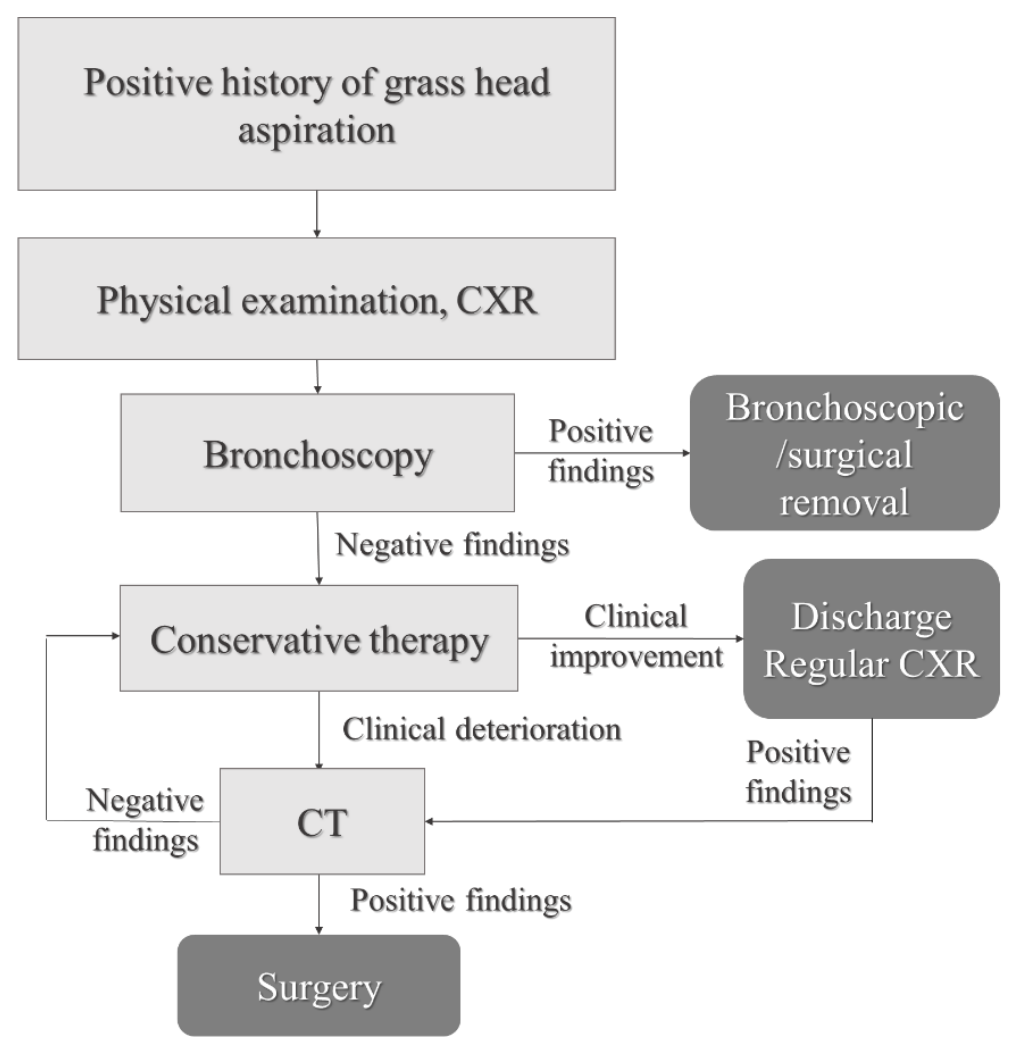

Figure 6. Treatment flowchart of grass head aspiration 


\subsection{Contemporary diagnostic and treatment options of tracheobronchial injuries}

\section{Important characteristics of tracheobronchial injuries}

Tracheobronchial injury is an uncommon condition, which can easily become lifethreatening. The majority of patients $(30-80 \%)$ still die at the scene of the accident $(13,14)$. Post-mortem analyses show a $2.8 \%$ incidence of TBI after blunt trauma in adults, previously described by Bertelsen and Howitz (41). Among adults with neck or chest injury, reaching the emergency department, the incidence of TBI is estimated at $0.2-8 \%(13,42,43)$. Incidence among children is even lower, probably due to the relatively fewer cases involving motor vehicle accidents, or violent interpersonal conflicts (44), and also special anatomical features. It is difficult to estimate incidence, although accoerding to clinical studies, it is estimated to be between $0.7-2.8 \%$ (12). Despite of low incidence, associated mortality is estimated to be 8.7$30 \%(15,16,45,46)$.

Early diagnosis is essential in patient survival. Avoiding airway obstruction with early, successful surgical management are vital for reaching improved outcome. The lack of typical clinical symptoms and various radiological signs often delay diagnosis. In order to reach improved treatment, the possibility of an airway injury should be kept in mind, and one should be aware of typical symptoms and proper management. Through the presentation of our short case series, contemporary diagnostic and treatment strategies of TBI located on the neck and around the bifurcation are discussed.

\section{Experience with unique cases of tracheobronchial injuries in our practice}

Case 1

A 44-year-old woman found under a bus in an accident was referred to our hospital. Hypoxemia was seen despite oxygen therapy, and subcutaneous emphysema was present in the jugulum. Primary management according to ATLS (Advanced Trauma Life Support) (47) protocol was applied in the nearest county hospital and CT of the head, neck, thorax and abdomen with CT angiography were performed. The 
following injuries were revealed: left-sided pulmonary contusion, right-sided pneumothorax, with occlusion of the right subclavian artery and multiple rib fractures on both sides. Despite chest decompression on the right side, the patient still had hypoxemia. At this point, airway injury was suspected and a double-lumen endotracheal tube (DLT) was inserted to reach isolated, single-lung ventilation on the left side. Respiratory parameters hardly improved ( $\mathrm{SpO} 280 \%$ with 100\% oxygen therapy), and she was transferred to our department for further work-up. Upon arrival circulation was unstable and required noradrenalin support, blood pressure was high $(150 / 90 \mathrm{mmHg})$ but gradually decreasing, and $\mathrm{O} 2$ saturation was $93 \%$. The right side of the thorax has been deformed and sunk with diminished breathing sounds over the right lower lobe. Bronchoscopy revealed rupture of the right main bronchus at the level of the carina. After double-lumen tube intubation to the left bronchus urgent right sided posterolateral thoracotomy was performed. A large pneumomediastinum was found, with intact mediastinal pleura. After opening the mediastinal pleura, a $4 \mathrm{~cm}$ tear was discovered on the lower third of the membranous trachea, running along to the left main bronchus $1 \mathrm{~cm}$ distal to the bifurcation. In addition, the right main bronchus was almost completely separated from the carina. The rupture of the membranous part of the trachea and the left main bronchus was reconstructed with interrupted 3-0 absorbable sutures, and the right main bronchus was sutured to the carina with interrupted sutures. The anastomosis was covered with an intercostal peicle muscle flap. The injury of the subclavian artery did not require urgent vascular surgery. Recovery was uneventful. The chest tube was removed on the sixth postoperative day, and she was discharged from the intensive care unit for rehabilitation on the seventh day.

\section{Case 2}

A 12-year-old girl was transferred to our hospital after falling down from a truck trailer from $60 \mathrm{~cm}$ hight, with the trailer passing through her chest. At the scene of the accident she had respiratory distress and subcutaneous emphysema on her neck. Since tension pneumothorax was suspected, a right-sided decompression with a needle and endotracheal intubation was carried out. Blood clots were found in the larynx during intubation. On arrival, extended neck- and chest emphysema, and no breathing sounds over the left lung were detected. During ATLS management chest tubes were inserted on both sides, thus her condition became stable. Computed tomography of the head, neck, thorax and abdomen revealed pulmonary contusion on both sides, subcutaneous emphysema and fracture of collum chirurgicum humeri. In addition, pneumomediastinum caused by rupture of the bifurcation was suspected. Bronchoscopy showed deformity of the bifurcation, with an intact lumen. A tear on the posterior wall of the right main bronchus was also found. The patient was stable, with acceptable ventilation and respiratory parameters, and expended lungs on both sides. After two days parameters did not improve, still requiring respiratory support, with repeated bronchoscopy confirming the need for surgery. A right sided posterolateral thoracotomy was performed on the third day with single lumen endotracheal tube. A large pneumomediastinum was found with intact mediastinal pleura. Ventilation with single lumen tube was 
sufficient, but when opening the mediastinal pleura, all ventilated air escaped. Urgent exploration was necessary: a longitudinal laceration in the midline of the trachea ran along the bifurcation - a 2-cm-long rupture on the pars membranacea and also a $2-\mathrm{cm}$ on pars cartilaginea, - with the two main bronchi separated. After a short exploration, the endotracheal tube was placed into the right and later the left main bronchus guided by the operator's finger. A complete reconstruction of the ruptured carina was performed with interrupted 3-0 absorbable sutures, and the suture line covered with a pedicled intercostal muscle flap to separate it from the oesophagus. After uneventful recovery, chest tubes were removed on the 3rd day, and she was discharged on the $11^{\text {th }}$ postoperative day.

Case 3

A 9-year old boy was referred to the emergency ward after being injured as a passenger in a car accident. The car rolled over and crashed into a tree. At the scene of the accident the child coughed up some blood, soon afterwards he needed resuscitation, which was successful. Prior to transportation intubation and left thoracotomy was performed. After arrival, primary management was carried out, according to ATLS protocol. A contusion sign was found over his neck on physical examination, certainly caused by the safety belt. He was stable and ventilation was satisfactory, therefore CT scan was performed. It revealed a rapidly spreading subcutaneous emphysema, starting from the deep cervical region, reaching through the wall of the thorax and abdomen. A small amount of pneumomediastinum was also noted, without signs of pneumothorax. An over-infalted tracheal tube cuff was also noted. The following additional injuries were seen: severe cerebral oedema and hypoxemia with brain injury, left tibial fracture and right-sided pulmonary contusion. Based on the history of a direct cervical trauma accompanied by deep cervical emphysema spreading to the abdomen, the possibility of tracheal laceration was considered. Otolaryngologist examined and excluded the presence of tracheal rupture above and below the site of the endotracheal tube cuff. During surgery a complete transection between the first and second tracheal rings was found, with the ends of the ruptured parts located $3 \mathrm{~cm}$ from each other. The cuff was lying between the two separated tracheal parts. The distal half of the tube ended in the lower trachea and provided satisfactory ventilation. Primary closure was done with tension-free interrupted sutures, and a drain was placed for two days. By using a chin-to-chest stitch neck flexion was ensured with a tension-free anastomosis. Due to the severe brain damage and pulmonary contusion, extubation could not be managed in the operating room, and the patient required long-term ventilatory support. Both laryngeal oedema and tracheal stenosis developed, thus tracheostomy was performed with the patient receiving steroids. Successful extubation was managed on the $11^{\text {th }}$ postoperative day, and the tracheostomy cannula was removed after one week, without any sign of stenosis. 


\section{Discussion}

\section{a. Epidemiology of TBI}

Injury of the tracheobronchial tree can occur during iatrogenic or traumatic events, which include blunt, or penetrating injury of the neck and thorax. The majority of patients with TBI are involved in high-velocity car-, or a motor accidents. Other injuries include falling from height, crush trauma, or pedestrian accidents $(43,48)$. Blunt trauma is responsible for TBI in approximately $94 \%$ of cases in children, while penetrating injuries are more frequent in adults $(49,50)$. All of our cases were caused by blunt traumas.

Blunt neck traumas mostly occurred due to direct injury, or sudden hyperextension. A typical example of direct force is when the trachea is pushed towards the esophagus and the stable vertebral body by an elevated seatbelt, as seen during our third case (Figure 7). Other typical direct mechanism in children causing compression and tracheal injury is the so-called clothesline injury, when for instance riding a bicycle, the extended neck collides with a branch, or clothesline $(44,50)$. Falling onto the edge of a piece of furniture at home is also a well known type of neck trauma among children (16). Based on this mechanism, it can be declared that the site of tracheal rupture tends to be at the exact level of the direct trauma and it is often associated with esophageal injury. Rapid hyperextension mostly appears when a vehicle is hit from the back, usually followed by smashing of the neck into the dash-board, thus the name: dash-board tracheal injury.

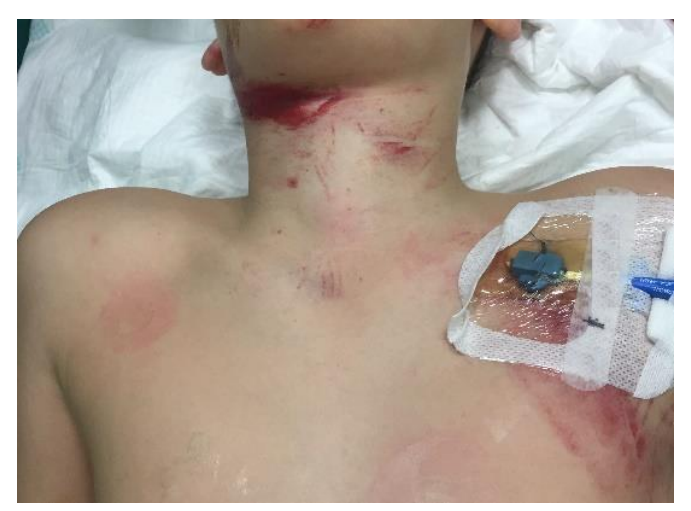

Figure 7. Contusion of the neck and left shoulder, suggesting the presence of tracheal injury in our third case - Courtesy of University of Szeged, Dep. of Surg.- Jozsef Furak M.D. 
The trachea is more vulnerable at the cervical region, and its injuries are frequently more visible compared to intrathoracic airway lesions. Immature pediatric larynx differs from the rigid adults larynx. Initially, the infant larynx is positioned as high as the fourth cervical vertebra, and descends gradually until reaching the adult position. The infant mandible is more prominent than the adult, therefore the larynx is mainly protected by the mandible (44). Calcification of the larynx begins at the age of 2 and keeps on developing until adulthood. These result in a cartilaginous, flexible larynx, which can resist fracture more easily (50).

The paper of Kirsh et al. declared three different types of mechanisms, causing intrathoracic TBI during blunt traumas (51). The most common mechanism is a sudden anteroposterior compression, when these forces lead to lateral separation of the carina. In our first two case, TBI developed due to the abovementioned mechanism, when the vehicle caused an anteroposterior compression of the chest. The second type includes compression of the chest with closed glottis, causing abruptly increased airway pressure. The third type is based on the relative fixation at the level of the bifurcation and the cricoid cartilage, while the lungs are more mobile inside the pleural space. In this case an acceleration-deceleration mechanism can cause a shearing force with disruption of the airway. These explain that bronchial injuries mostly occur in motor vehicle accidents, caused by flexion-extension forces.

\section{b. Location, size and classification of TBI}

Upper airway injuries can be classified as supraglottic, transglottic, or subglottic types based on the site of laceration. Generally, the membranous part of the trachea is the weakest point and most likely to rupture, compared with the anterior and lateral wall which are strengthend by the U-shaped tracheal rings. Therefore, the anterior trachea is mostly injured in penetrating injuries, while the posterior wall is mainly affected in blunt traumas (42).

Literature data is consistent, that $75-90 \%$ of TBIs in blunt trauma are located within 2-3 $\mathrm{cm}$ from the carina and $60 \%$ of them are within $1 \mathrm{~cm}(13,14,48,52)$. The majority of data states that the main bronchi are most frequently injured (66-85\%), especially the right side (27-61\%) $(14,48,53,55,56)$. In comparison, the cervical trachea $(4-19 \%)$, distal thoracic trachea $(22 \%)$, 
left proximal main bronchus (17-32\%), or lobar orifices are less frequently affected (14-16\%) $(15,53,54)$.

The above mentioned right sided predominance is probably explained by the fact that the right bronchus is more fixed in the thorax, but not as much protected by surrounding vascular structures, as the left one. The right side also has larger connecting lung parenchyma with a shorter bronchus (52). In addition, the right bronchial tree lays close to the thoracic vertebrae, and is at risk for compressing to the spine during an accident. These anatomic specialities explain that right-sided lesions are more frequent and have higher mortality rates than the ones on the left side. In comparison, due to the abovementioned protective adjacent structures, diagnosis tends to be delayed in left-sided cases (14).

There is few literature data on the morphological classification and related treatment options of TBI patients. In case of laryngotracheal ruptures, Schaefer and Fuhrman defined a system based on the depth of the lesion (55), and recommended management strategies, that are still referred to date. In Group I. and II. minor endolaryngeal laceration, or mucosal oedema and hematoma are present, with also non-displaced fracture in Group II. Massive oedema, displaced fracture and vocal cord paralysis are defined as Group III. While in Group IV. unstable fracture, or more than two fracture lines are present. In Group V. a complete laryngeal separation is present. This study recommends conservative therapy in Group I., tracheostomy in II., and urgent tracheostomy and surgical exploration in Group III., IV. and V.

Another method described by Cardillo et al. declares different levels of laceration and offers a key to decide between conservative and surgical treatment (57) (Figure 8). Level I and II are defined as an incomplete laceration in the layers of the tracheal wall. Level III is a complete lesion in all muscular layers of the trachea with herniation of the esophagus or mediastinal tissue. Cardillo's prospective study recommends non-surgical management for Level I, II and III/A, in which 29 adult patients with a lesion at these levels were successfully treated with fibrin glue. The presence of esophageal injury, or mediastinitis (Level III/B) determines the need for prompt surgical treatment. Although this classification method is originally used in postintubation tracheobronchial lacerations, some authors promote this method in the management of traumatic airway injuries as well. 


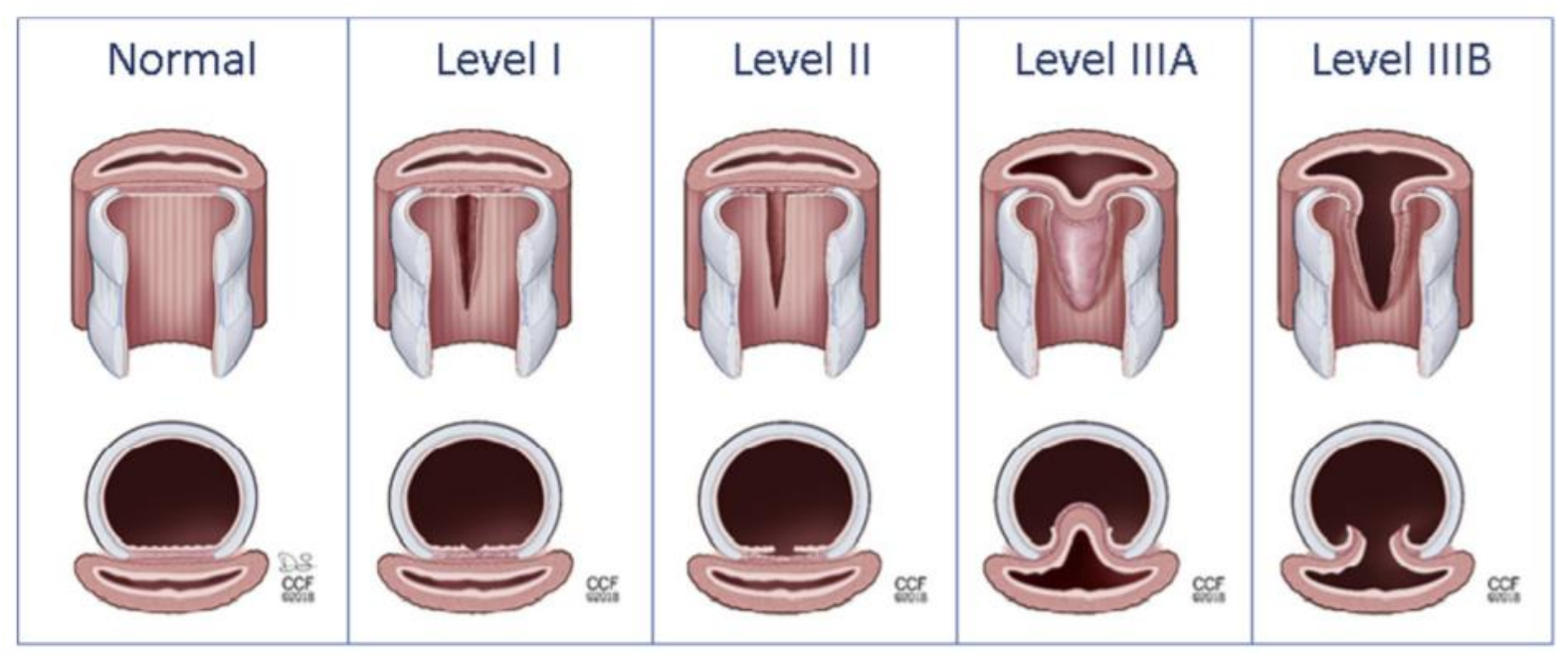

Figure 8. Morphologic classification of tracheal lesions, based on the classification by Cardillo et al. (Images created by illustrator David Schumick, reported by Grewal et al. (58))

These classification systems are universal for patients in all age groups, and are frequently used during pediatric airway injuries (16). However, we should keep in mind, that clinical evaluation and management strategies for children may differ from adult protocols, as respiratory distress may develop more rapidly in children. (15), while on the other hand conservative therapy is more often successful in infant cases.

\section{Diagnostic procedure and difficulties}

\section{a. Symptoms}

Tracheobronchial injuries are difficult to diagnose due to the unspecific physical symptoms and radiological appearance. The presence of concomitant injuries can obscure the symptoms of airway lesions and can lead to delayed diagnosis and early fatal outcome (13). Therefore, it cannot be overemphasised that a high level of suspicion is the most important factor for prompt diagnosis. TBI has a delayed diagnosis in $25 \%$ to $68 \%$ of patients (52). Due to peculiar anatomical features in children (such as immature and mobile tracheobronchial tree), symptoms and severity may range from almost asymptomatic to life-threatening forms (47). Therefore 
initial diagnosis still poses a challenge for clinicians, and sometimes days or even weeks pass after the initial trauma, until the correct diagnosis is established.

The most common symptoms are tachypnoea, respiratory distress (59-100\%), and haemoptysis (14-74\%). Dyspnea and stridor can be an early sign of tracheal stenosis. Cervical trauma leads to hoarseness, or dysphonia, caused by laryngeal fracture, vocal cord tears, or recurrent laryngeal nerve injury. Nevertheless, subcutaneous emphysema is the classic feature (35-87\%) of TBI. Extended subcutaneous emphysema could even reach the abdomen and lower extremities (54). When a progressive emphysema following blunt trauma occurs, the possibility of TBI should always be considered $(13,14,52)$, as during our third case. Expanding subcutaneous emphysema which stops after intubation verifies the diagnosis. We should bear it in mind that emphysema and pneumomediastinum may not appear initially (52). Even in patients with complete transection, adequate lung ventilation can be managed due to surrounding tissues which cover separated fragments and prevent air-leaks.

Lesion in the lower airway may cause pneumothorax in $17 \%-72 \%$ of patients, as during our first two cases. Airway injury generally maintains a massive air-leak through chest drainage and prevents lung re-expansion, which should always alert the clinician of a possible TBI $(13,42,52,59)$, as it happened during our first case. On the other hand, a complete transection may lead to occlusion of the airway caused by the surrounding soft tissue, which prevents development of pneumothorax.

Another sign is due to the air-filled mediastinal tissue, causing a specific murmur, called Hamman's sign. It is synchronously detected with heartbeat on auscultation (13).

Up to $40 \%-100 \%$ of patients with blunt chest traumas are associated with injuries of the abdomen, head, or skeletal structures (43). For instance, the most frequent coexistent injuries in the cervical region are esophageal injuries, hemopneumothorax, carotid artery-, or jugular vein injuries, recurrent laryngeal nerve injuries, cervical spine and laryngeal injuries. Intrathoracic blunt trauma often involves great vessels, the esophagus and heart, and causes pulmonary contusion, rib, or burst vertebral fracture.

\section{b. Current radiology options}

Various indirect signs of airway lesions can be detected by radiologic studies routinely performed in acute emergency settings; however direct, obvious findings rarely occur. Since 
the introduction of Advanced Trauma Life Support (ATLS), TBI patients have lower mortality rates (14). Primary survey includes eFAST examination (Extended Focused Assessment with Sonography in Trauma) recommended by $10^{\text {th }}$ edition of ATLS (47). It is highly sensitive for detecting presence of pneumo-, or hemothorax. The transducer should be placed on the left and right side, in the superior pectoral region, and both $\mathrm{M}$ and $\mathrm{B}$ modes should be applied. Subcutaneous emphysema may add a limitation, but can suggest the presence of tracheobronchial injury.

In case endotracheal intubation is successful, but persistent hypoxaemia without pneumothorax is seen during eFAST, airway injury should be considered (59). The three typical signs of TBI on chest X-ray are subcutaneous emphysema, pneumothorax and pneumomediastinum $(13,14,49,53)$. In case subcutaneous emphysema is accompanied by the elevation of the hyoid bone above $\mathrm{C} 3$ in the neck, the possibility of an upper airway transection and rising of the larynx is high. The endotracheal tube outside of the airways, or an overinflated endotracheal tube cuff are both important radiologic findings $(13,48)$ requiring more emphasis. These are exact, direct signs of TBI, and the importance of these conditions are discussed in detail in Study 3.

Other indirect signs that may appear are: tracheal deformity, discontinuation of the tracheal, or bronchial air column. The only direct and pathognomic CXR sign of TBI is the "fallen lung sign". This means that complete transection of the bronchi makes the separated lung collapse laterally and posteriorly, while in other cases of pneumothorax, the lung tends to collapse to the site of the hilum $(43,48,54)$.

These aforementioned diagnostic tools facilitate the suspicion of an airway injury. At this point Bagga et al. defined the criteria urging the need for a prompt chest CT: 1) hypoxaemia without pneumothorax after endotracheal intubation, 2) massive air leak after tube thoracotomy and persistent pneumothorax, 3) progressive subcutaneous emphysema and pneumomediastinum (59).

Multi-slice detector computed tomography (MDCT) is superior to traumatic radiology modalities, since it can identify and localize lesions and also detect concomitant injuries. Unfortunately, direct visualization of tracheobronchial disruption, such as complete transection, tracheal ring fracture, or fallen lung sign are less reliable. In case of upper airway injury, CT scan may identify paratracheal air, deep cervical emphysema, or pneumomediastinum. In case 
of patients with lower airway injury, CT can reveal the following findings: pneumomediastinum, mediastinitis, mediastinal haematoma, focal intimal flap in the lumen, bronchial stenosis, or obstruction $(43,53,54,59,60)$. Although direct signs are less common, the presence of interstitial tracheobronchial air, or gas dispersion around the lesion are remarkable, and should be alerting signs. The sensitivity of CT imaging is up to $71-100 \%(13,43,59,60)$. However there are still some false negative results due to circumferential oedema and haemorrhage, thus a negative CT does not exclude the presence of a TBI $(15,55)$.

As CT maintains higher radiation exposure and potentially harmful long-term consequences, especially in children (61), it remains a concern during infant cases. Some clinical studies question the need for routine CT imaging in cases of TBI. Shires at al. claimed that CT did not add any surplus information on pediatric laryngotracheal injuries after thorough physical examination (50). Delayed treatment due to CT examination may pose life-threatening consequences, especially in children, who tend to develop shock and acute decompensation even quicker (15). CT imaging has the drawback of a limited ability to visualize laryngeal injury due to poor mineralization, thus significant rate of false negative results are seen $(15,50)$. Nevertheless, these condiserations are relevant in selected cases of laryngotracheal injuries, when unambiguous symptomps are present, and definitive diagnosis can be achieved by other diagnostic methods. In other cases, especially in lower airway lesions, CT can be an indispensable diagnostic tool to ensure suspicion of TBI and exclude other associated injuries.

During our first case, CT only revealed a right-sided pneumothorax. The patient had subcutaneous emphysema, and she still had hypoxemia even after chest drainage, which strongly suggested the presence of TBI. In Case 2, respiratory distress, subcutaneous emphysema, blood clot in the larynx were found, and pneumothorax on both sides were managed by chest tubes. CT revealed pneumomediastinum, which led to a suspicion of TBI. In the third case, contusion of the neck was noted on physical examination. CT showed rapidly expanding subcutaneous emphysema and pneumomediastinum as indirect signs (Figure 9), and a direct sign of TBI was also revealed, as the endotracheal tube cuff was overinflated and was present outside of the tracheal wall (Figure 10). In order to confirm diagnosis and identify the site of lacerations, all three patients required bronchoscopy. 


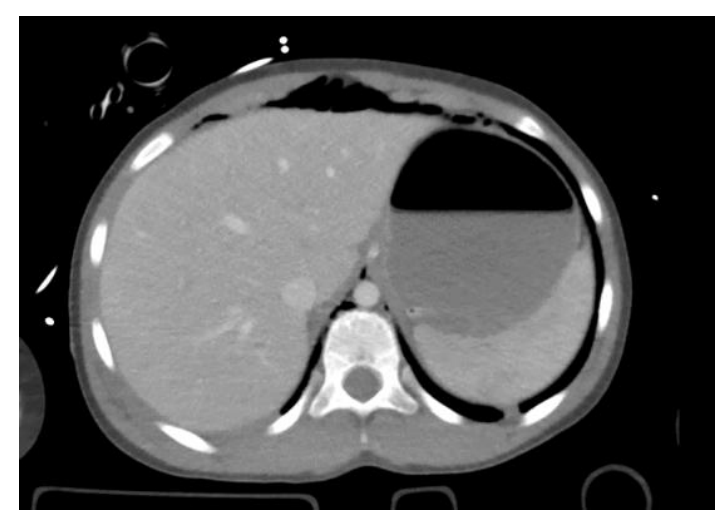

Figure 9. Extremely spreading extraperitoneal emphysema described on CT in Case 3 - Courtesy of Affidea Ltd.

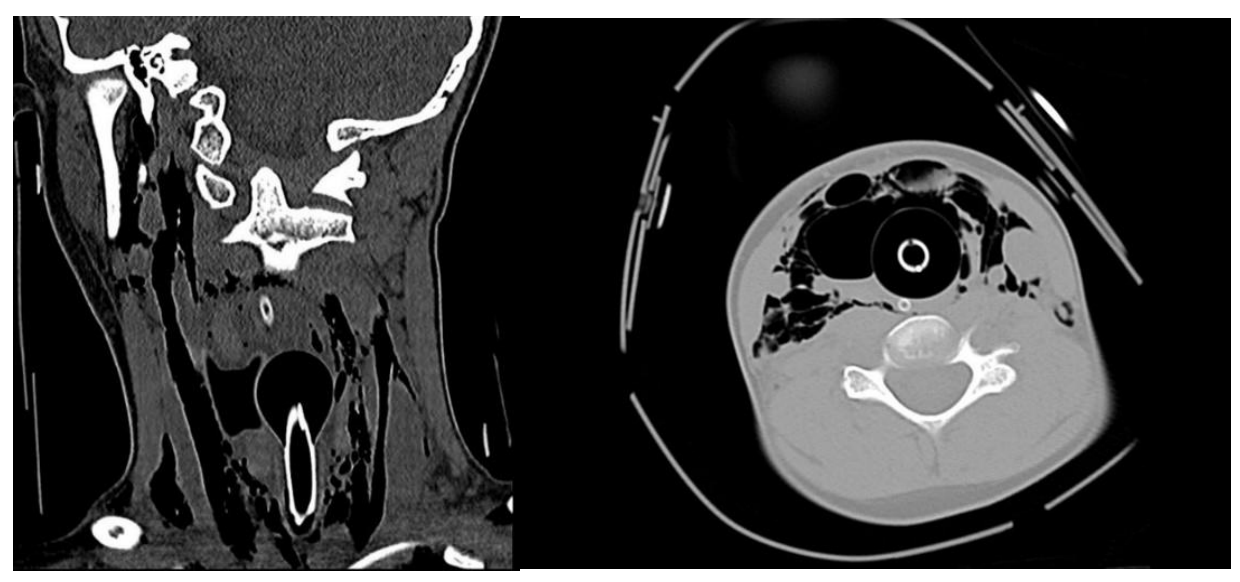

Figure 10. CT of the first patient: overinflated ETT cuff, and deep cervical emphysema, the tracheal wall can not be detected at the level of the balloon - Courtesy of Affidea Ltd.

After CT, additional three-dimensional reconstruction, or virtual bronchoscopy should be considered as a valuable help in diagnosis $(56,60)$. Esophageal injuries are frequently seen, especially after direct neck trauma, when the trachea is smashed towards the esophagus and cervical vertebral bodies. Contrast esophagogram can facilitate diagnosis and reveal potential posterior tracheal wall rupture (47). In case of complete tracheal rupture, injury of the esophagus should also be considered. 


\section{c. Endoscopic examination}

Laryngoscopy and bronchoscopy are crucial parts of diagnostic work-up. Although CT has several advantages, these still remain the "gold standard" diagnostic tools. Laryngoscopy should be performed by otolaryngologist in case of cervical trauma, or in suspected laryngeal injury. It should preferably be done with fibreoptic laryngo- or bronchoscopy through an endotracheal tube.

The most common findings include tear of wall, blood clot filling the airway and collapsed lumen distal from the haematoma (13). In some mild cases, with simple mucosal laceration, a small amount of blood could be the only sign for clinicians. In case the endotracheal tube lays over the laceration, the lesion may be missed. That is the reason why some patients are diagnosed only after extubation. In case of a highly suspected tracheal injury, it is better to deflate the tube cuff and manipulate with the tube during bronchoscopy.

It is a quick and easy diagnostic tool, which could be applied even in case of cervical spine injury (52). All patients with suspected airway injuries should undergo this process as early as possible $(14,42,43,59)$. Still, some studies have doubts about tracheobronchoscopy in children, as it is an invasive method, and small infant airways can easily be obstructed during the process $(62,63)$. A recent review article demonstrated that endoscopy is not always the optimal approach for small children, and suggested that immediate operative endoscopy could be more efficient and safe (15).

In Case 1, bronchoscopy revealed a rupture of the right main bronchus at the level of the carina. It was defined in Cardillo's classification (57) as a Level III/B laceration, needing prompt surgical treatment, since having a high risk of developing mediastinitis. Emergency surgery was performed and a $4 \mathrm{~cm}$ long tear on the membranous trachea was detected with complete transection of the right main bronchus. During the second case, bronchoscopy showed deformation of the bifurcation, with an intact lumen, which was classified as Level III/A laceration and could be managed either surgically, or non-surgically. During the operation we found a longitudinal laceration separating the two main bronchi. During the last case, CT showed an overinflated tube cuff and laryngoscopy confirmed the suspected laceration at the level of the endotracheal tube balloon. A completely transected trachea was seen between the first and second tracheal rings. According to Cardillo, this was a Level III/B laceration, or a 
Group V. rupture by Schaefer and Fuhrman's laryngotracheal rupture classification, thus urgent surgery was indicated.

\section{Modern treatment options of tracheobronchial injuries}

\section{a. Emergency airway management}

According to literature data, in patients suffering from TBI, the most important priority is immediate intubation. Intravenous muscle relaxants should be avoided, since the transected airway is possibly attached and supported only by surrounding muscles. In addition, an attempt to blindly intubate may lead to a false external passage from the airway, therefore intubation under visualization of a flexible bronchoscope is preferred $(13,14,48,53)$. It is important, that the tube bypass the injured part and the cuff be inflated distally to avoid further disruption, or even complete transection $(13,53,64)$. Low-tidal volume, or low pressures may also prevent further disruption.

Tracheostomy is rarely necessary. It is recommended in patient with severe maxillofacial trauma, unstable fractures of the face, palpable deformity over the trachea, extreme oedema or haemorrhage, leading to obstruction, and inability to intubate. Furthermore, in some young pediatric cases, tracheostomy may be prefered to endotracheal intubation, as intubation can completely obstruct an already damaged and tenuous airway, eventually leading to emergency tracheostomy, but under worse circumstances $(16,44)$.

Tracheostomy is suggested to be positioned caudal to the level of the injury. We should be aware that in case of a complete transection, the distal part of the trachea may slip into the mediastinum (52,59). After tracheostomy, a definitive airway repair can be managed later.

Disruption at the site of the bifurcation may require a double-lumen tube, or selective endobronchial intubation (64). In a difficult situations finger guidance may be applied, leading the tube through the thoracotomy. 


\section{b. Surgical management}

Treatment of airway injuries should be individualized for every patient, considering comorbidities, location of the lesion and clinical presentation (42). Following secured airway and mandatory diagnostic steps, the patient should be transferred to the operating room for reconstruction as soon as possible. The most important aim of surgery is 1) preventing airway obstruction, 2) avoiding spontaneous healing complications (such as stenosis), 3) avoiding mediastinitis 4) stopping massive air leaks and improving sufficient ventilation (13).

Independent of the lesion site, a primary reconstruction should be attempted. The proximal part of the trachea is accessible through a low collar incision, which ensures good exposure of vascular, or esophageal injuries. In case of mid-third tracheal injuries, a partial sternotomy over the manubrium with, or without a collar incision provides a good view. We should keep in mind, that in case of a complete transection in the cervical trachea, the distal part can easily retract into the mediastinum, leading to severe symptoms and making it more difficult to approach it.

The distal third of the trachea, bifurcation and bronchi can be reached via a left, or right thoracotomy in the $4-5^{\text {th }}$ intercostal space (13). Accessing the left main bronchus maintains some difficulties and seldom requires mobilisation of the aorta and division of the ligamentum arteriosum (14). In some selected cases a median sternotomy can be an alternative approach. We mostly apply right sided posterolateral thoracotomy if intrathoracic trachea, carina, right main bronchus, or the proximal half of the left main bronchus are injured.

In case of small transverse tears, interrupted sutures are recommended, with the knots outside the lumen, to reduce postoperative irritation and coughing, and to prevent late stenosis. Longitudinal lacerations can be repaired by continuous running sutures. Larger disruption, or complete transection requires refreshing of damaged edges prior to primary end-to-end anastomosis $(13,54)$. Excessive airway mobilization should be avoided in order to prevent devascularisation, which may lead to late sequelae, such as dehiscence, or stenosis. As far as possible, primary repair of the carina should be performed and its resection should be avoided. In case a resection is inevitable, a maximum of 3-4 cm long section of the airway can be resected $(13,43,52,65)$.

In case there is an extremely wide tissue damage and a primary repair cannot be performed, tracheostomy should be done. In case of laryngocricoid injury, or injury of both recurrent 
laryngeal nerves, protective tracheostomy is recommended $(13,52)$. The site of tracheostomy should be as far as possible from the tracheal reconstruction, reducing the risk of dehiscence, or stenosis. When resection is inevitable, a tension-free anastomosis can be provided by blunt dissection of the avascular pretracheal plane. Flexion of the neck can also be maintained for a few days, for the purpose of a tension-free anastomosis. In order to carry out an intrathoracic tension-free anastomosis, an opening on the pericardium, or the division of the inferior pulmonary ligaments can be performed. These techniques allow 1-2 cm long mobilization of the airways $(13,14,52,53)$.

In case of severe airway disruption, protective tissue flap (pleura, pericardium, mediastinal fat, muscle flap) can be used to cover the anastomosis, or separate the esophagus $(13,43,54)$. Severely distorted lung parenchyma occasionally requires lung resection.

All three patients had primary anastomosis with 3-0 interrupted absorbable sutures, without any resection. Two cases with lower airway injury had a pedicled intercostal muscle flap for covering, thus we successfully avoided postoperative dehiscence. Laryngotracheal laceration needed extended mobilisation of the trachea since the separated parts were $3 \mathrm{~cm}$ apart from each other (Figure 11.).

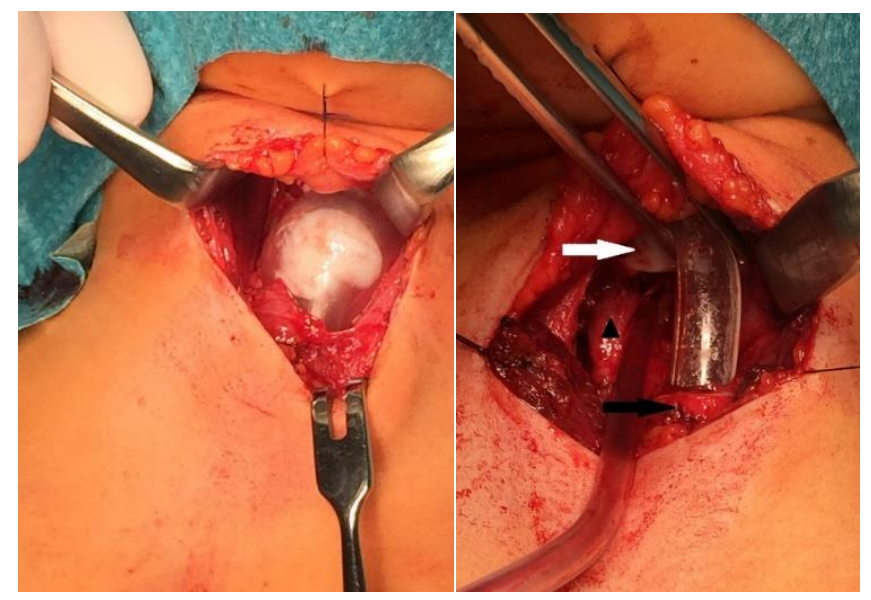

Figure 11. Intraoperative image in Case 3. Ruptured tracheal parts are marked by arrows. Triangle shows intact esophagus. - Courtesy of University of Szeged, Dep. of Surg.- Jozsef Furak M.D. 


\section{c. Non-surgical management}

In some selected cases conservative treatment can be considered. Criteria include the following: tear under $2 \mathrm{~cm}$, or one-third of the diameter, clinically stable patient, spontaneous breathing, or minimal ventilatory support, and no sign of mediastinitis, or sepsis $(13,14,52,54)$.

In children, age may play a significant role in the decision, as younger children have excellent healing tendencies (50). One of the largest series in children with conservative treatment is reported by Wood et al. (65). In their institution, 7 children were treated conservatively, though only one of them was injured during trauma, while other lesions were caused by intubation (66). The youngest child was a 6-week-old boy, who recovered successfully after a tracheal lesion, due to conservative management (50). The most frequent complication after conservative treatment is formation of granulation tissue, also reported in literature $(50,66)$. Injuries caused by intubation have better prognosis, since they often produce longitudinal tears on the posterior wall, compared to traumatic injuries, which result in irregular shaped, horizontal lesions.

According to Cardillo et al. (57) who classified airway lacerations, an incomplete rupture of the muscular wall (L. I, II) or simple, complete wall rupture (L. III/A) can be managed nonoperatively. Surgical approach is reserved for complete laceration associated with mediastinitis, or coexistent esophageal injury (L. III/B), or in cases of separation between the two trachealor bronchial parts.

Conservative treatment is mostly suggested in iatrogenic cases. These patients need antibiotic therapy and drainage. The largest, previously reported, and conservatively managed tracheal laceration was $4 \mathrm{~cm}$ long (14).

Self-expanding metallic stents (SEMS) can be used as alternative treatment in patients who have high surgical risk, or severe comorbidities. This novel method is also useful in case of late stenosis caused by granulation tissue at the site of the laceration (53).

In case of unstable patients with ventilatory failure, extracorporeal membrane oxygenation (ECMO) is a valuable possibility, since it has already been successfully applied by several authors both in adults (67-71) and in children $(72,73)$. 


\section{d. Postoperative Management}

The earliest possible postoperative extubation is recommended to minimize local trauma caused by the tube, or elevated endotracheal pressure $(14,48,52,56)$. In case of isolated airway injury, extubation can be safely performed in the operating room. In case mechanical ventilation is necessary, the lowest possible pressure should be applied, and frequent pulmonary toilet is required to remove secretion (52). Aggressive pulmonary toilet is especially important for patients having vocal cord paralysis, in case a mini tracheostomy seems to be helpful to allow direct tracheal aspiration. In every case the clinician should be convinced that the tube cuff does not overlie the repaired site.

The use of steroids is still controversial, but is routinely used by some authors $(50,74)$. In our third case, corticosteroids were necessary to reduce oedema and to achieve earlier extubation.

Positive long-term outcome is expected when early surgery can be performed (Figure 12.). This also depends on the severity of additional injuries, developing septic condition, need for intubation and intensive care unit support. Postoperative bronchoscopy should be performed after 7 to 10 days to ensure satisfactory healing and to exclude stenosis $(50,52)$

Complications develop in up to $25.8 \%$ of patients, which includes early anastomotic dehiscence, mediastinitis, or airway stenosis 2-6 weeks later (13). The incidence of stenosis and anastomotic dehiscence is 5-6\% (52). These may lead to recurrent pneumonia, bronchiectasis, or complete obstruction (14). After 3 to 6 months some patients need airway resection and reconstruction. Injury of the larynx, or recurrent laryngeal nerves may lead to phonation problems.

Initial diagnosis of TBI can be missed in $25-68 \%$ of cases (52). This is mostly due to the serious associated injuries, which obscure the symptoms of airway lesion. In other cases, the rupture might be small enough to cause only mild symptoms. The respiratory tract heals in 1-4 weeks after injury, but stricture may appear due to granulation tissue. This stenosis can cause obstruction of the airway, leading to consequent pneumonia, bronchiectasis, or atelectasis (52). 


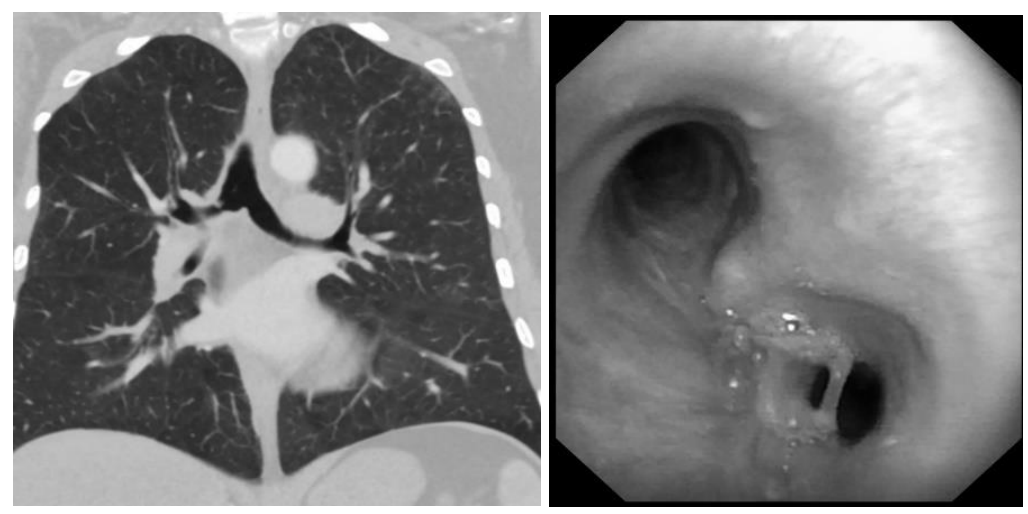

Figure 12. Check-up chest $\mathrm{CT}$ after 6 months, in our first case treated according to the aforementioned strategies, and bronchoscopy showing the anastomosis - Courtesy of Affidea Ltd., and University of Szeged, Dep. of Surg.- Jozsef Furak M.D. 


\section{Summary of the most important current treatment strategies and process}

An algorithm for surgical, or non-surgical management of airway injuries is suggested. The most important steps to prompt primary management are summarized according to contemporary literature (Figure 13,14).

When patients present at the emergency department, the first step is to consider whether she, or he had a type of trauma which can lead to airway injury (previous flexion-extension, or compression forces, sign of an elevated seat-belt, blood in vomit, or sputum). The most important symptoms we should look for on physical examination include dyspnea, respiratory distress, subcutaneous emphysema, suspected pneumothorax and contusion over the neck and thorax. Stable patients should be referred for prompt MDCT, and if there are signs of tracheobronchial injury (pneumomediastinum, spreading subcutaneous emphysema, persistent pneumothorax despite tube thoracostomy), then laryngoscopy, or bronchoscopy should be immediately performed in order to localise the site of laceration. When it is necessary, fiberoscope guided intubation can be a feasible option, at least when laryngoscopy/bronchoscopy is applied. We have an opportunity to perform esophagoscopy if a posterior wall disruption is suspected and if diagnosis is unclear. In case an airway injury is confirmed, the patient should be transferred to the operating room as soon as possible. However, in some selected cases when special criteria are fulfilled, conservative therapy can be a valuable alternative choice. These conditions are: tear under $2 \mathrm{~cm}$, or one-third of diameter, clinically stable patient, spontaneous breathing, or minimal ventilatory support, and no sign of mediastinitis, or sepsis. Conservative therapy should be suspended and surgical management should be carried out at any time when the normal healing process, or patient condition is not satisfactory. 


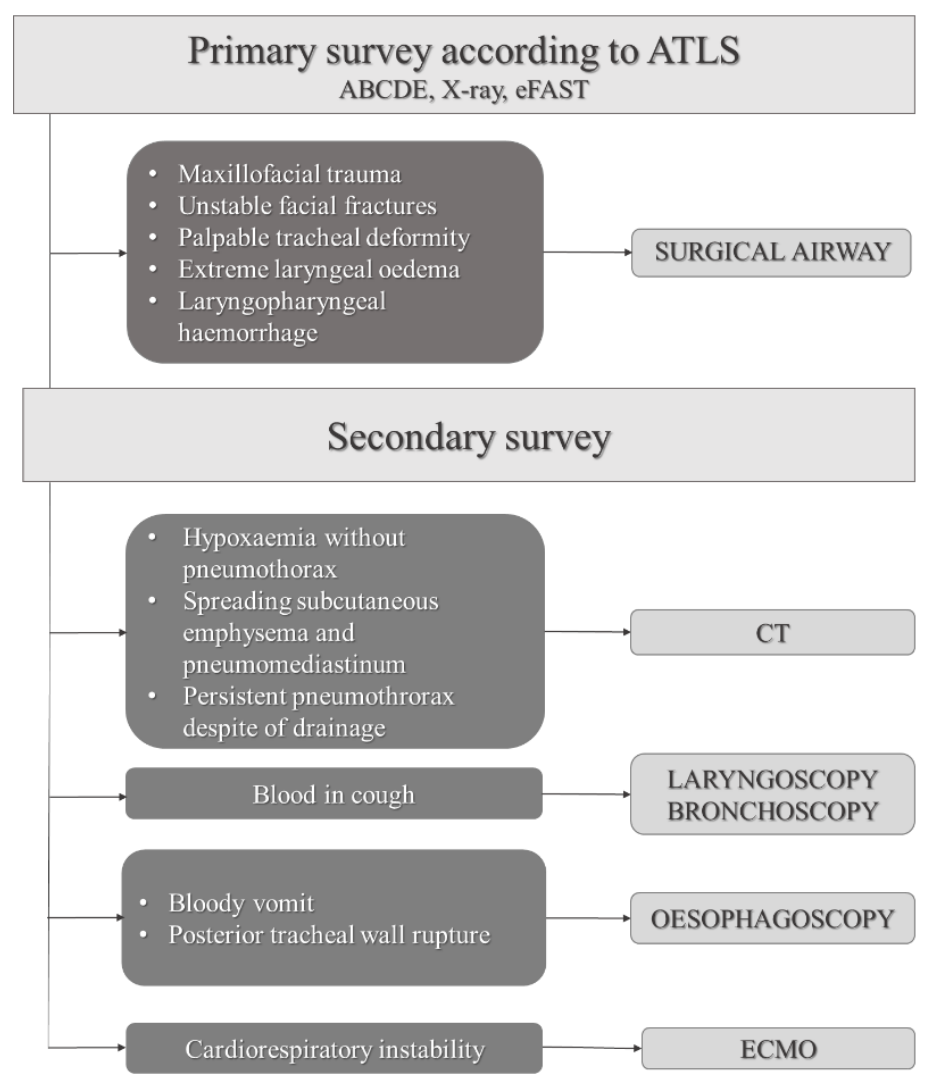

Figure 13. Diagnostic and emergency intervention flowchart

- $<2 \mathrm{~cm}$

- $<1 / 3$ diameter

- Cardioresp. stable

- Min. ventilatory support

- No sepsis

- No mediastinitis

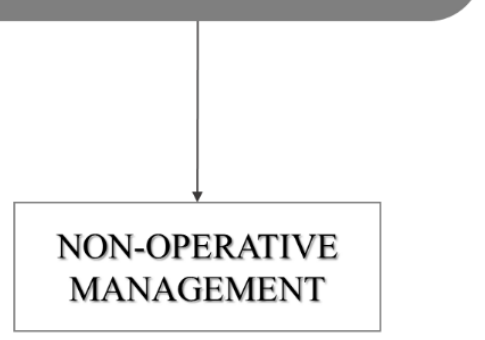

- $>2 \mathrm{~cm}$ or $>1 / 3$ diameter tear

- Complete separation

- Cardioresp. unstable

- Sepsis

- Mediastinitis

- Coexistent severe injury

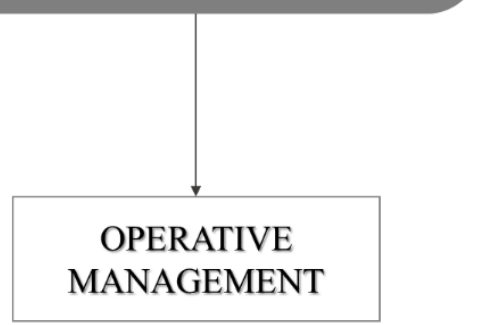

Figure 14. Treatment flowchart of TBI 


\subsection{The role of overinflated endotracheal tube cuff in the diagnosis of tracheal injuries}

While blunt thoracic, or neck trauma remains the most frequent cause of tracheobronchial lesions, a difficult intubation, or prolonged intubation associated with nasogastric tube insertion are also significant causative factors. In these cases an early diagnosis and treatment is also crucial and can be life-saving. Our purpose was to highlight the diagnostic role of the direct radiological sign of overinflated endotracheal tube cuff. Our patients had an overdistended endotracheal balloon herniated to the extratracheal space through the rupture of the tracheal wall. These overinflated balloons were detectable during each of our treated cases on radiographical imaging. This is a direct and pathognomic sign of airway injury, suggesting complete rupture of the tracheal wall.

\section{Background of non-traumatic tracheal lacerations}

Traumatic tracheal injury followed by intubation is a major factor of complete tracheal laceration. Inflation of the endotracheal balloon at the level of the lesion may convert a partial injury to complete disruption involving each layer of the wall, or even to complete transection resulting in two separate tracheal segments. In addition, difficult intubation without trauma may also be responsible for tracheal damage.

Most cases happen during rapid sequence intubation, when an abrupt movement, or excessively inflated cuff with high pressure causes tracheal rupture (75). The most frequent predictive factors are several intubation attempts, repositioning of ETT without deflation of the cuff, coughing during intubation, improper sized tube, abrupt movement of the head, or neck during intubation (75,76). In most cases lesions appear on the pars membranacea of the trachea. Women are more frequently involved in postintubational tracheal injuries due to weaker posterior tracheal wall and different anatomical structures (such as relatively shorter trachea) (76). Children are also often involved in postintubation injuries, due to structural and physiological differences. For instance, funnel-shaped pediatric cricoid lumen, highly cartilaginous larynx, or weaker and more flexible wall (66). 
Another significant cause is long-term intubation combined with nasogastric tube insertion, which can easily lead to tracheoesophageal fistula (TEF) formation. One of the predictive factors of TEF development is a more than 12-days-long intubated patient. Numerous other predisposing factors are known, such as tube displacement, steroids, infection, hipotension, diabetes, or older age. The main cause is a high pressure ETT cuff, which maintains consistent tension on the tracheal wall, consequently causing local damage in blood supply, ischaemia, necrosis, and may finally lead to fistula formation (77).

The abovementioned mechanisms are the main reasons of tracheal injury, where the ETT cuff may potentially become overdistended and herniated through the tracheal wall. It is wellknown, that these damages could be avoided with correct pressure control, preventing hyperinflation. Keeping the standard cuff pressure between $20-30 \mathrm{cmH}_{2} \mathrm{O}$ in adults (78) and 15-20 $\mathrm{cmH}_{2} \mathrm{O}$ in children, is strongly recommended (79). A recent prospective study by Rahmani et al. showed that cuff pressure should be measured by manometer in every single case, as palpation of the cuff alone resulted in meaningfully higher pressure (an average 118.15 $\left.\mathrm{cmH}_{2} \mathrm{O}\right)(80,81)$.

More emphasis should be placed on medical staff training, to be aware of possible postintubation complications and to be able to prevent them. Numerous measures were recommended by Fan et al. (76) to lower the risk of tracheal injury: 1) selecting the correct size for ETT; 2) gentle intubation without abrupt movement; 3) the stylet should be retracted distally to the vocal cord; 4) slowly inflated cuff and measuring proper cuff pressure; 5) deflating cuff before any tube movement and fixing ETT tightly to avoid tube displacement.

As we have already seen in part 3.2. (Contemporary diagnostic and treatment options of TBI), diagnosis of tracheal injuries has numerous difficulties. Although various signs associated with TBI may be present, atypical signs dominate in most cases. In short, the initial suspicion of tracheal rupture is mostly based on the presence of subcutaneous emphysema, or respiratory distress.

Moreover, as we have also pointed out in part 3.2., radiological diagnosis has many difficulties detecting TBI. Ultrasound, or eFAST is only useful in confirming the presence of subcutaneous emphysema, or pneumothorax (47). Neck and chest X-ray is mostly helpful in noticing extreme emphysema, pneumomediastinum and pneumothorax. Neck and chest MDCT 
is by far the most informative radiological modality, however mostly the same signs prevail (pneumothorax, pneumomediastinum, emphysema). Tracheal deformity, discontinuity of the tracheal, or bronchial air column rarely appear. MDCT scan may also identify paratracheal air, deep cervical emphysema, focal intimal flap in the lumen, or obstruction $(43,53,54,59,60)$.

Laryngoscopy and bronchoscopy are crucial parts of diagnostic work-up, however the possibility of a false negative result also exists in TBI cases.

\section{Cases treated in our practice}

\section{Case 1}

The aforementioned 9-year-old boy is one of our patients, diagnosed due to the overinsufflated tracheal balloon. He was injured in a car accident, as the seat-belt crossed his neck (see in detail in part 3.2 , Case 3). The cuff had a diameter of $2.56 \mathrm{~cm}$, while his tracheal diameter was only $1.03 \mathrm{~cm}$, thus a tracheal lesion was considered. Otolaryngologist excluded the presence of tracheal rupture above and below the site of the endotracheal tube cuff. Due to patient condition, we were not able to deflate and move the cuff into a different level. During urgent surgery, a complete transection between the first and second tracheal rings was found, with the cuff lying between the two separate tracheal parts (see also Figure 11). Based on these findings, a tracheal lesion was likely, which was completed due to RSI, causing complete separation of the trachea.

Case 2

A 31-year-old women was transferred to the emergency department, who suffered a car accident. She was not buckled up and the airbag did not open. At the site, she had a GCS of 7 (2-4-1), and RSI was performed. CT revealed vertebral fracture of $\mathrm{C} 1$, subcutaneous emphysema of the neck expanding into the mediastinum, and the abdominal region. The ETT cuff had a $3.24 \mathrm{~cm}$ diameter on CT, while the distal tracheal diameter was $1.53 \mathrm{~cm}$. Bronchoscopy confirmed a lesion on the pars membranacea. Urgent surgery revealed a $6-\mathrm{cm}$-long rupture on the posterior wall. The tube cuff was at the site of the laceration, but was present extratracheally between the trachea and the esophagus. They were dissected from each other by the balloon. Primary closure with tension-free, interrupted sutures and preventive tracheostomy was performed. We started postoperative antibiotic therapy, and neither mediastinitis, nor stenosis developed.

Case 3

TEF developed in a 76-year-old women after long-term intubation and insertion of nasogastric tube. Imaging showed an overinflated ETT cuff. Hyperinflated ballon had a diameter of $3.5 \mathrm{~cm}$ on CXR. CT was unable to identify a $1.5 \mathrm{~cm}$ long section of the trachea, but detected pneumomediastinum. CT showed the 
space between the trachea and the esophagus where the overinflated balloon was located. Primary closure from neck incision was performed. Postoperative antibiotic therapy was initiated, mediastinitis did not develope.

\section{Results and experience with overinflated balloon sign}

Despite extended examination modalities, diagnosis of TBI is not always granted. It is often based on indirect radiological signs. We would like to highlight the importance of the overinsufflated ETT cuff, which is a direct and patognomical sign of tracheal injury. This sign rarely occurs, however it adequately shows the exact level of the lesion, and suggests complete tracheal wall ruption (82-85). This overinflated cuff may be detectable even on CXR in some cases. We have successfully confirmed this sign in an infant, moreover this same method can also be used in adult patients, as we did in two of our cases. The first patient, a 9-year-old boy had an incomplete tracheal lesion caused by a car accident. This lesion was converted into a complete tracheal separation during RSI due to the insufflation of ETT cuff. CT showed an overinflated balloon with deep cervical emphysema (Figure 15). During urgent surgery we saw the cuff lying between the two separate tracheal parts.

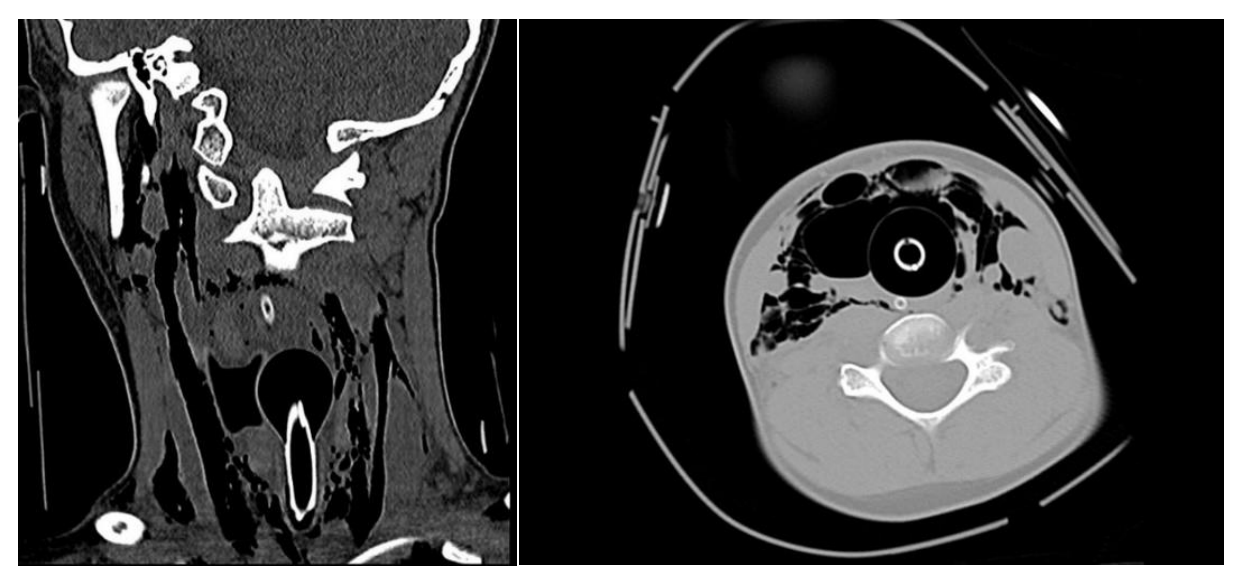

Figure 15. CT of the first patient: overinflated ETT cuff, and deep cervical emphysema, the tracheal wall can not be detected at the level of the balloon - Courtesy of Affidea Ltd. 
One of the adult patients had a posteriorly herniated cuff due to the lesion of the pars membranacea, which was revealed by CT. Due to its herniation into the esophagus, the balloon had a deformed shape (Figure 16,17). In a recent study, Chen et al. (83) emphasized that a partially herniated balloon may have a distorted shape instead of a ball-shape. It can also be a Mickey-mouse, or dumbbell shape, which can easily be detected.

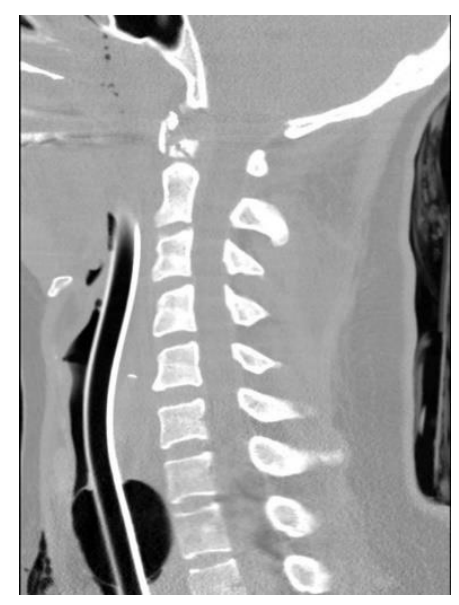

Figure 16. Posteriorly herniated cuff suggesting complete rupture of pars membranacea in the second patient - Courtesy of Affidea Ltd.

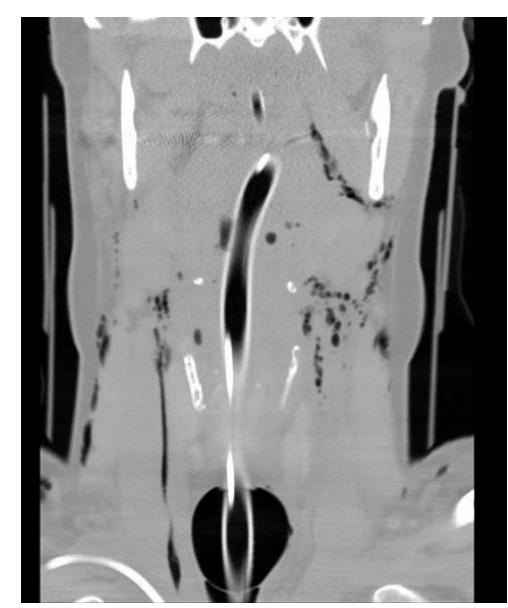

Figure 17. Hyperinflated cuff and subcutaneous emphysema in the second patient

Courtesy of Affidea Ltd.

The third patient is a unique case, as her tracheal lesion was diagnosed by CXR after prolonged intubation (Figure 18). Her TEF was confirmed on CT.

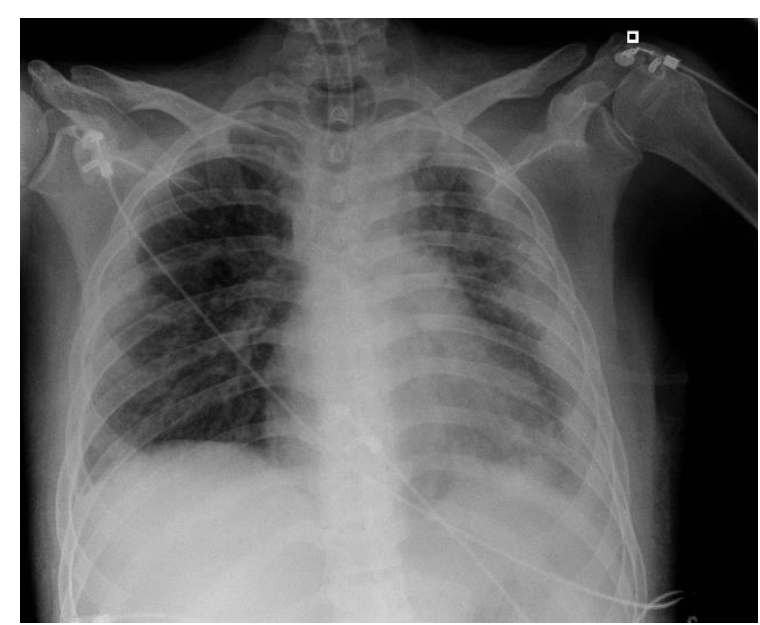

Figure 18. Overinflated ETT cuff seen on chest X-ray of the third patient. Courtesy of Affidea Ltd. 


\section{Summary of the possibilities of overinflated balloon-sign}

In unusual cases an overinsufflated balloon can suggest the presence of tracheobronchial injury, and indicates the need for bronchoscopy. However, this sign is able to locate the lesion without any need for a fiberoscope.

In our first case, laryngoscopy excluded injury proximally and distally from the cuff, hence the balloon was placed exactly over the site of the injury. Despite this, the overdistended cuff on CT has already shown the presence and site of the laceration. In the second case laryngoscopy localised the lesion, however CT had already revealed it due to the hyperinflated balloon. Thus we would like to emphasis that hyperinflated balloons can safely confirm the presence and even identify the location of the lesion.

Henceforward this condition requires the same treatment as other TBI cases. In case of a small TEF, primary suture is recommended. In individual cases, in the absence of gross air leaks, or respiratory distress, conservative therapy may be warranted. A large fistula usually requires limited tracheal resection and the use of interpositioned tissue over the suture line.

In summary, neck or thoracic blunt trauma and difficult intubation suggest the presence of a tracheal injury, especially in the presence of a subcutaneous emphysema. We should bear the possibility of TEF in mind during long-term intubation. On some case the only diagnostic sign is the overinflated balloon-sign seen on CXR or CT, thus early fiberoscopy can be carried out. 


\section{Summary and key results}

I. We emphasized the difficulties of inflorescence aspiration, and revealed its most significant characteristics (Study 1). One of the most important point is that a negative bronchoscopic result and improved inflammatory markers do not exclude the presence of bronchial grass head, thus an asymptomatic child should be followed up thoroughly to recognise late complications in time. Regular diagnostic steps (such as chest ultrasound, or X-ray) should be performed to localise early inflammation. Chest CT is a useful tool to confirm diagnosis and identify the position of the foreign body. Its use is strongly recommended if pheripheral changes are noted on radiologic examinations.

II. Surgical removal is opted when the grass head stayes peripheral, and localised inflammation evolves, but prior to severe complications. Our aim was to enhance the importance of segmentectomy as a tissue-saving option, which has special relevance in children. When grass head is found in a completely localized inflammation site or abscess, anatomical segmentectomy with the removal of the affected bronchus may be the preferred choice. In case of extended inflammation and abscess, or in obscure conditions, lobectomy may be required. We also offer an achievable algorithm to define recommended treatment steps in the management of grass head aspiration, and to facilitate decision making (Study 1).

III. An algorithm for surgical or non-surgical management of blunt airway injury has been recommended. The most important steps of prompt primary management according to contemporary literature was summarized (Study 2.).

IV. We defined the role of overinflated balloon sign, which may be the only radiological change in some TBI cases. It is a clearly visible, direct sign of tracheal injury, which can lead us to an early and definitive diagnosis. The balloon is able to show the exact location of the lesion, according which, targeted fiberoscopy can be performed. Although overinflated ballon seen in tracheobronchial injuries is not a 
new radiological concept, it is extremely underestimated and underreported. More emphasis should be placed on this sign during diagnostic procedures, and both radiologists and traumatologists should be aware of its role to achieve early diagnosis and prompt treatment. Medical staff should be trained to avoid postintubation airway injury caused by a hyperinflated cuff. 


\section{Acknowledgements}

First and foremost, I wish to express my gratitude to Dr. József Furák for having offered me the opportunity, and for his constant support and encouragement along the scientific process. I am also greatful to Dr. Tamás Kovács, who assured my interest in the field of scientific research and encouraged me to participate in scientific life. I would like to offer my thank to Prof. Dr. Endre Varga for giving support through the process of publication. I would like to thank all my colleagues for their support in my everyday work. I would also like to thank all members of my family for their huge emotional support, with special regards to my husband for the encouragement, and his huge help with writing process. 


\section{References}

1. Blair D, Kim R, Mills N, et al. A heuristic approach to foreign bodies in the paediatric airway. Int J Pediatr Otorhinolaryngol. 2014;78(12):2262-2266. doi:10.1016/j.ijporl.2014.10.029

2. Zaupa P, Saxena AK, Barounig A, et al. Management strategies in foreign-body aspiration. Indian J Pediatr. 2009;76(2):157-161. doi:10.1007/s12098-008-0231-2

3. Janahi IA, Khan S, Chandra P, et al. A new clinical algorithm scoring for management of suspected foreign body aspiration in children. BMC Pulm Med. 2017;17(1):61. doi:10.1186/s12890-017-0406-6

4. Haller L, Barazzone-Argiroffo C, Vidal I, et al. Safely Decreasing Rigid Bronchoscopies for Foreign-Body Aspiration in Children: An Algorithm for the Emergency Department. Eur J Pediatr Surg. 2018;28(3):273-278. doi:10.1055/s-0037-1603523

5. Grover S, Bansal A, Singhi SC. Airway foreign body aspiration. Indian J Pediatr. 2011;78(11):1401-1403. doi:10.1007/s12098-011-0488-8

6. Fidkowski CW, Zheng H, Firth PG. The anesthetic considerations of tracheobronchial foreign bodies in children: a literature review of 12,979 cases. Anesth Analg. 2010;111(4):1016-1025. doi:10.1213/ANE.0b013e3181ef3e9c

7. Grassi R, Faggian A, Somma F, et al. Application of imaging guidelines in patients with foreign body ingestion or inhalation: literature review. Semin Ultrasound CT MR. 2015;36(1):48-56. doi:10.1053/j.sult.2014.10.004

8. Tovar JA, Vazquez JJ. Management of chest trauma in children. Paediatric Respiratory Reviews. 2013 Jun;14(2):86-91. doi:10.1016/j.prrv.2013.02.011.

9. Minervini F, Scarci M, Kocher GJ, et al. Pediatric chest trauma: a unique challenge. J Vis Surg 2020;6:8. doi:10.21037/jovs.2019.11.05

10. Sartorelli KH, Vane DW. The diagnosis and management of children with blunt injury of the chest. Semin Pediatr Surg. 2004;13(2):98-105. doi:10.1053/j.sempedsurg.2004.01.005 
11. Allen GS, Cox CS Jr. Pulmonary contusion in children: diagnosis and management. South Med J. 1998;91(12):1099-1106. doi:10.1097/00007611-199812000-00002

12. Slimane MAA, Becmeur F, Aubert D, et al. Tracheobronchial ruptures from blunt thoracic trauma in children. Journal of Pediatric Surgery. 1999 Dec 1;34(12):1847-50. doi:10.1016/S0022-3468(99)90328-7

13. Prokakis C, Koletsis EN, Dedeilias P, et al. Airway trauma: a review on epidemiology, mechanisms of injury, diagnosis and treatment. J Cardiothorac Surg. 2014;9:117. Published 2014 Jun 30. doi:10.1186/1749-8090-9-117

14. Linegar A, Schulenburg R. Tracheobronchial Trauma In: Kuzdzal J, Asamura H, Detterbeck F et al. (ed.) ESTS Textbook of Thoracic Surgery Vol 2. Medycyna Praktyczna, Cracow, 2015; pp. 937-943.

15. Cheng J, Cooper M, Tracy E. Clinical considerations for blunt laryngotracheal trauma in children. J Pediatr Surg. 2017 May;52(5):874-80. doi:10.1016/j.jpedsurg.2016.12.019

16. Sidell D, Mendelsohn AH, Shapiro NL, et al. Management and Outcomes of Laryngeal Injuries in the Pediatric Population. Ann Otol Rhinol Laryngol. 20110 1;120(12):787-95. doi:10.1177/000348941112001204

17. Jackson C. Grasses as foreign bodies in the bronchus and lung. Laryngoscope. 1952;62(9):897-923. doi:10.1288/00005537-195209000-00002

18. Godfrey RC. The behaviour of inhaled grass inflorescences. Lancet. 1957;273(6989):273-274. doi:10.1016/s0140-6736(57)90727-4

19. Woolley PV Jr. Grass inflorescences as foreign bodies in the respiratory tract. J Pediatr. 1955;46(6):704-706. doi:10.1016/s0022-3476(55)80176-x

20. Felger, R.S., S. Rutman, J. Malusa. 2014. Ajo Peak to Tinajas Altas: A flora of southwestern Arizona. Part 6. Poaceae - grass family. Phytoneuron 2014-35: 1-139.

21. Nasr A, Forte V, Friedberg J, et al. Successful bronchoscopic retrieval of Timothy grass from the airway. J Pediatr Surg. 2005;40(4):E39-E41. doi:10.1016/j.jpedsurg.2005.01.028

22. Maayan C, Avital A, Elpeleg ON, et al. Complications following oat head aspiration. Pediatr Pulmonol. 1993;15(1):52-4. doi:10.1002/ppul.1950150109 
23. Kanbur S, Evman S, Dogruyol T, et al. A Bronchopleurocutaneous Fistula Caused by Unexpected Foreign Body Aspiration: False Barley (Hordeum murinum). Ann Thorac Surg. 2015;100(6):e125-127. doi:10.1016/j.athoracsur.2015.07.043

24. Karagöz B, Köksal Y, Varan A, et al. An unusual case of grass inflorescence aspiration presenting as a chest wall tumour. Pediatr Radiol. 2006 May 1;36(5):434-6. doi:10.1007/s00247-005-0088-8

25. Dindar H, Konkan R, Cakmak M, et al. A bronchopleurocutaneous fistula caused by an unusual foreign body aspiration simulating acute abdomen. Eur J Pediatr. 1994 Feb;153(2):136-7. doi:10.1007/BF01959227

26. Seydell, E. M. (1937). Spontaneous perforation of the wall of the chest by an aspirated foreign body. Archives of Otolaryngology - Head and Neck Surgery, 26(2), 189-194. doi:10.1001/archotol.1937.00650020205008

27. Hilman BC, Kurzweg FT, McCook WW et al. Foreign body aspiration of grass inflorescences as a cause of hemoptysis. Chest. 1980;78(2):306-9. doi:10.1378/chest.78.2.306

28. Clery AP, Ellis FH, Schmidt HW. Problems associated with aspiration of grass heads (inflorescences). JAMA. 1959;171(11):1478-1484. doi:10.1001/jama.1959.03010290036009

29. Başok O, Yaldiz S, Kilinçer L. Bronchiectasis resulting from aspirated grass inflorescences. Scand Cardiovasc J. 1997;31(3):157-9. doi:10.3109/14017439709058086

30. Pattison CW, Leaming AJ, Townsend ER. Hidden foreign body as a cause of recurrent hemoptysis in a teenage girl. Ann Thorac Surg. 1988;45(3):330-331. doi:10.1016/s00034975(10)62475-7

31. Dudgeon DL, Parker FB Jr, Frittelli G, et al. Bronchiectasis in pediatric patients resulting from aspirated grass inflorescences. Arch Surg. 1980;115(8):979-983. doi:10.1001/archsurg.1980.01380080069014

32. Diggory P, Ross BA. Lung abscess resulting from grass inflorescence. Thorax. 1984;39(6):480. doi:10.1136/thx.39.6.480 
33. Jewett TC Jr, Butsch WL. Trials with treacherous Timothy grass. J Thorac Cardiovasc Surg. 1965;50:124-126.

34. Spencer MJ, Millet VE, Dudley JP, et al. Grassheads in the tracheobronchial tree: two different outcomes. Ann Otol Rhinol Laryngol. 1981 Aug;90(4 Pt 1):406-8. doi:10.1177/000348948109000425

35. Harries JT, Hartley RC, Parry TE. A chest wall swelling due to inhaled grass. Postgrad Med J. 1967;43(502):548-549. doi:10.1136/pgmj.43.502.548

36. Cavens TR, McGee MD, Miller RR, et al. Pneumocutaneous fistula secondary to aspiration of grass. J Pediatr. 1973;82(4):737-738. doi:10.1016/s0022-3476(73)80614-6

37. Choremis C, Theodorou S, Athanasiades T, et al. Spontaneous elimination of inhaled grass inflorescences through the lung and chest. Arch Dis Child. 1964;39(206):406-408. doi:10.1136/adc.39.206.406

38. Newson TP, Parshuram CS, Berkowitz RG, et al. Tension pneumothorax secondary to grass head aspiration. Pediatr Emerg Care. 1998;14(4):287-9. doi:10.1097/00006565199808000-00013

39. Ammari FF, Faris KT, Mahafza TM. Inhalation of wild barley into the airways: two different outcomes. Saudi Med J. 2000;21(5):468-470.

40. Kothari V, Sonkhya N, Sharma C, et al. Pneumothorax secondary to foreign body inhalation in an infant. Indian J Otolaryngol Head Neck Surg. 2006 Apr;58(2):211-2.

41. Bertelsen S, Howitz P. Injuries of the trachea and bronchi. Thorax. 1972 Mar;27(2):188-94. doi:10.1136/thx.27.2.188

42. Gallagher JJ. Management of blunt pulmonary injury. AACN Adv Crit Care. 2014 Dec;25(4):375-86; quiz 387-8. doi:10.1097/NCI.0000000000000059

43. Welter S. Repair of tracheobronchial injuries. Thorac Surg Clin. 2014 Feb;24(1):4150. doi:10.1016/j.thorsurg.2013.10.006

44. Gold SM, Gerber ME, Shott SR, et al. Blunt Laryngotracheal Trauma in Children. Arch $\begin{array}{llll}\text { Otolaryngol Head Neck } & \text { 1997;123(1):83-87. }\end{array}$ doi:10.1001/archotol.1997.01900010093014 
45. Alemayehu H, Aguayo P. Pediatric Blunt Thoracic Trauma. J Pediatr Intensive Care. 2015;4(1):35-39. doi:10.1055/s-0035-1554987

46. Wu CY, Chen TP, Liu YH, et al. Successful treatment of complicated tracheobronchial rupture using primary surgical repair. Chang Gung Med J. 2005;28(9):662-667

47. Thoracic Trauma In: Claire M. (ed.) ATLS Advanced Trauma Life Support, Student Course Manual. American College of Surgeons, 2018; pp. 64-79.

48. van Roozendaal LM, van Gool MH, Sprooten RTM, et al. Surgical treatment of bronchial rupture in blunt chest trauma: a review of literature. J Thorac Dis. 2018 Sep;10(9):5576-83. doi: 10.21037/jtd.2018.08.22

49. Dominguez E, Torre CDL, Sánchez AV, et al. Severe Tracheobronchial Injuries: Our Experience. Eur J Pediatr Surg. 2015 Feb;25(01):71-6. doi:10.1055/s-0034-1386642

50. Shires CB, Preston T, Thompson J. Pediatric laryngeal trauma: a case series at a tertiary children's hospital. Int J Pediatr Otorhinolaryngol. 2011;75(3):401-408. doi:10.1016/j.ijporl.2010.12.016

51. Kirsh MM, Orringer MB, Behrendt DM, et al. Management of tracheobronchial disruption secondary to nonpenetrating trauma. Ann Thorac Surg. 1976;22(1):93-101. doi:10.1016/s0003-4975(10)63961-6

52. Altinok T, Can A. Management of Tracheobronchial Injuries. Eurasian J Med. 2014 Oct;46(3):209-15. doi:10.5152/eajm.2014.42

53. Shemmeri E, Vallières E. Blunt Tracheobronchial Trauma. Thorac Surg Clin. 2018;28(3):429-434. doi:10.1016/j.thorsurg.2018.04.008

54. Zhao Z, Zhang T, Yin X, et al. Update on the diagnosis and treatment of tracheal and bronchial injury. J Thorac Dis. 2017;9(1):E50-E56. doi:10.21037/jtd.2017.01.19

55. Santiago-Rosado LM, Sigmon DF, Lewison CS. Tracheal Trauma. In: StatPearls. Treasure Island (FL): StatPearls Publishing; July 10, 2020.

56. Alassal MA, Ibrahim BM, Elsadeck N. Traumatic intrathoracic tracheobronchial injuries: a study of 78 cases. Asian Cardiovasc Thorac Ann. 2014;22(7):816-823. doi:10.1177/0218492313516777 
57. Cardillo G, Carbone L, Carleo F, et al. Tracheal lacerations after endotracheal intubation: a proposed morphological classification to guide non-surgical treatment. Eur J Cardiothorac Surg. 2010;37(3):581-587. doi:10.1016/j.ejcts.2009.07.034

58. Grewal HS, Dangayach NS, Ahmad U, et al. Treatment of Tracheobronchial Injuries: A Contemporary Review. Chest. 2019;155(3):595-604. doi:10.1016/j.chest.2018.07.018

59. Bagga B, Kumar A, Chahal A, et al. Traumatic Airway Injuries: Role of Imaging. Curr Probl Diagn Radiol. 2020;49(1):48-53. doi:10.1067/j.cpradiol.2018.10.005

60. Newbury A, Dorfman JD, Lo HS. Imaging and Management of Thoracic Trauma. Semin Ultrasound CT MR. 2018;39(4):347-354. doi:10.1053/j.sult.2018.03.006

61. Brenner D, Elliston C, Hall E, et al. Estimated risks of radiation-induced fatal cancer from pediatric CT. AJR Am J Roentgenol. 2001;176(2):289-296. doi:10.2214/ajr.176.2.1760289

62. Poli-Merol ML, Belouadah M, Parvy F, et al. Tracheobronchial injury by blunt trauma in children: is emergency tracheobronchoscopy always necessary?. Eur J Pediatr Surg. 2003;13(6):398-402. doi:10.1055/s-2003-44730

63. Heldenberg E, Vishne TH, Pley M, et al. Major bronchial trauma in the pediatric age group. World J Surg. 2005;29(2):149-154. doi:10.1007/s00268-004-7381-9

64. Elgendy H, Jilani T. Successful anesthetic management in a child after traumatic rupture of left main bronchus by a single-lumen cuffed-endotracheal tube. Ann Card Anaesth. 2014;17(4):292-295. doi:10.4103/0971-9784.142066

65. Dennis BM, Bellister SA, Guillamondegui OD. Thoracic Trauma. Surg Clin North Am. 2017;97(5):1047-1064. doi:10.1016/j.suc.2017.06.009

66. Wood JW, Thornton B, Brown CS, et al. Traumatic tracheal injury in children: a case series supporting conservative management. Int J Pediatr Otorhinolaryngol. 2015;79(5):716720. doi:10.1016/j.ijporl.2015.02.025

67. Biancosino C, Krüger M, Kühn C, et al. First Successful Surgical Reconstruction of Bilateral Transected Main Bronchi With Extracorporeal Membrane Oxygenation Support. Ann Thorac Surg. 2016;102(2):e135-e137. doi:10.1016/j.athoracsur.2016.01.009 
68. Ryu KM, Chang SW. Heparin-free extracorporeal membrane oxygenation in a patient with severe pulmonary contusions and bronchial disruption. Clin Exp Emerg Med. 2018;5(3):204-207. doi:10.15441/ceem.17.252

69. Hamilton EC, Lazar D, Tsao K, et al. Pediatric tracheobronchial injury after blunt trauma. J Trauma Acute Care Surg. 2017;83(3):554-556. doi:10.1097/TA.0000000000001579

70. Suh JW, Shin HJ, Lee CY, et al. Surgical Repair of a Traumatic Tracheobronchial Injury in a Pediatric Patient Assisted with Venoarterial Extracorporeal Membrane Oxygenation. Korean J Thorac Cardiovasc Surg. 2017;50(5):403-406. doi:10.5090/kjtcs.2017.50.5.403

71. Noh D, Lee CK, Hwang JJ, et al. Concomitant Avulsion Injury of the Subclavian Vessels and the Main Bronchus Caused by Blunt Trauma. Korean J Thorac Cardiovasc Surg. 2018;51(2):153-155. doi:10.5090/kjtcs.2018.51.2.153

72. Wada D, Hayakawa K, Maruyama S, et al. A paediatric case of severe tracheobronchial injury successfully treated surgically after early CT diagnosis and ECMO safely performed in the hybrid emergency room. Scand J Trauma Resusc Emerg Med. 2019;27(1):49. Published 2019 Apr 23. doi:10.1186/s13049-019-0628-0

73. Ballouhey Q, Fesseau R, Benouaich V, et al. Benefits of extracorporeal membrane oxygenation for major blunt tracheobronchial trauma in the paediatric age group. Eur $\mathbf{J}$ Cardiothorac Surg. 2013;43(4):864-865. doi:10.1093/ejcts/ezs607

74. Chatterjee D, Agarwal R, Bajaj L, et al. Airway management in laryngotracheal injuries from blunt neck trauma in children. Paediatr Anaesth. 2016;26(2):132-138. doi:10.1111/pan.12791

75. Baranyai Z, Kocsis A, Jósa V. Endotrachealis intubáció okozta trachearuptura sikeres sebészi ellátása [Successful surgical treatment of tracheal rupture caused by endotracheal intubation]. Orv Hetil. 2010;151(23):946-949. doi:10.1556/OH.2010.28774

76. Fan CM, Ko PC, Tsai KC, et al. Tracheal rupture complicating emergent endotracheal intubation. Am J Emerg Med. 2004;22(4):289-293. doi:10.1016/j.ajem.2004.04.012

77. Kaur D, Anand S, Sharma P, et al. Early presentation of postintubation tracheoesophageal fistula: Perioperative anesthetic management. J Anaesthesiol Clin Pharmacol. 2012;28(1):114-116. doi:10.4103/0970-9185.92460 
78. Talekar CR, Udy AA, Boots RJ, Lipman J, et al. Tracheal cuff pressure monitoring in the ICU: a literature review and survey of current practice in Queensland. Anaesth Intensive Care. 2014;42(6):761-770. doi:10.1177/0310057X1404200612

79. Neerja Bhardwaj. Pediatric cuffed endotracheal tubes. J Anaesthesiol Clin Pharmacol. 2013 Jan-Mar; 29(1): 13-18. doi: 10.4103/0970-9185.105786

80. Peters JH, Hoogerwerf N. Prehospital endotracheal intubation; need for routine cuff pressure measurement?. Emerg Med J. 2013;30(10):851-853. doi:10.1136/emermed-2012201388

81. Rahmani F, Soleimanpour H, Zeynali A, et al. Comparison of tracheal tube cuff pressure with two techniques: fixed volume versus pilot balloon palpation. J Cardiovasc Thorac Res. 2017;9(4):196-199. doi:10.15171/jcvtr.2017.34

82. Euathrongchit J, Thoongsuwan N, Stern EJ. Nonvascular mediastinal trauma. Radiol Clin North Am. 2006;44(2):251-viii. doi:10.1016/j.rcl.2005.10.001

83. Chen JD, Shanmuganathan K, Mirvis SE, et al. Using CT to diagnose tracheal rupture. AJR Am J Roentgenol. 2001;176(5):1273-1280. doi:10.2214/ajr.176.5.1761273

84. Rollins RJ, Tocino I. Early radiographic signs of tracheal rupture. AJR Am J Roentgenol. 1987;148(4):695-698. doi:10.2214/ajr.148.4.695

85. Scaglione M, Romano S, Pinto A, et al. Acute tracheobronchial injuries: Impact of imaging on diagnosis and management implications. Eur J Radiol. 2006;59(3):336-343. doi:10.1016/j.ejrad.2006.04.026 


\section{STUDY}




\title{
Surgical treatment of awn aspiration causing bronchopleural fistula and bronchiectasis: case reports
}

\author{
Anna Rieth ${ }^{1 *} \mathbb{D}$, Tamás Kovács ${ }^{1}$, Zoltán Novák², Katalin Kapus², Aurél Ottlakán ${ }^{3}$, Tibor Németh ${ }^{3}$ and József Furák ${ }^{3}$
}

\begin{abstract}
Background: Aspiration of grass inflorescences is an extremely rare phenomenon with potential diagnostic difficulties. Due to its special shape, each coughing and respiratory action helps its migration towards the periphery of lung, resulting late-onset, life-threatening complications. The diagnosis has some difficulties for the reason that soon after the aspiration initial symptoms, such as coughing, wheezing or vomiting disappear and bronchoscopy is mostly negative. At least serious complications such as tension pneumothorax, bronchopleurocutaneous fistula or even spontaneous percutan elimination may develope.

Case presentation: We present two cases of pleuropneumonia resulting from aspiration of the head of barley grass. Soon after the accidents initial symptoms diminished, inflammatory markers improved and bronchoscopy was unable to confirm the presence of awn. Despite of conservative treatment (antibiotics, physiotherapy, bronchodilators, expectorants, and inhalation) localized pulmonary inflammation developed after 1 and 9 months showed up on chest computed tomography. After ineffective conservative treatment, surgical resections became inevitable in order to remove chronically inflamed parts (lobectomy, segmentectomy) and foreign bodies. Both patients recovered and were discharged home after successful interventions.

Conclusions: Due to its peculiar shape and behaviour, awn inhalation is a special and atypical form of aspiration, thus great care and awareness is needed in its treatment. Negative bronchoscopic result does not exclude the presence of bronchial grass head. Symptomless child with negative bronchoscopy and improved inflammatory markers should be followed up thoroughly to recognize late complications in time. Regular diagnostic steps (chest ultrasound/X-ray) should be performed to localize potential chronic lung inflammation. Chest computed tomography is a valuable diagnostic tool for identifying and localising the foreign body. In cases with localized inflammation and peripheric localisation, segmentectomy can be a successful and safe alternative of lobectomy.
\end{abstract}

Keywords: Awn aspiration, Bronchopleural fistula, Bronchiectasis, Lung resection

\section{Background}

Aspiration of foreign body is a common problem especially in case of children, however inhalation of grass head is extremely rare. Grasses (Poaceae) are a family of flowering plants found on fields, roads or along rivers. The well-known barley grass (Horderum morinum) is one of the most widespread species in Europe. Their heads have a special shape with several spikes and bristles, which is responsible for the atypical progression

\footnotetext{
*Correspondence: rieth.anna@med.u-szeged.hu

${ }^{1}$ Division of Pediatric Surgery, Department of Pediatrics, University of Szeged,

14-15. Korányi Avenue, Szeged 6725, Hungary

Full list of author information is available at the end of the article
}

and symptoms of aspiration. After the accident only mild symptoms appear, such as coughing, wheezing or vomiting. The diagnosis has some difficulties for the reason that each coughing and respiratory action helps its migration towards the periphery of the lung, while its transfer to the opposite direction is impossible due to the several spikes. As it gets deeper initial symptoms disappear and bronchoscopy is mostly negative. These negative results and improved physical status may create a false sense of security either in physicians or parents. Nevertheless after a few days aspiration pneumonia, bronchocutaneous fistula, bronchiectasis and other serious even life-threatening complications may develop [1,

(c) The Author(s). 2019 Open Access This article is distributed under the terms of the Creative Commons Attribution 4.0 International License (http://creativecommons.org/licenses/by/4.0/), which permits unrestricted use, distribution, and reproduction in any medium, provided you give appropriate credit to the original author(s) and the source, provide a link to the Creative Commons license, and indicate if changes were made. The Creative Commons Public Domain Dedication waiver (http://creativecommons.org/publicdomain/zero/1.0/) applies to the data made available in this article, unless otherwise stated. 
2], eventually resulting in surgery [3-5]. Case reports in literature declare that without surgical treatment percutaneous elimination through the chest wall can develop [3, 6-8]. Our cases describe pleuropneumonia and bronchiectasia caused by awn, the bristly head of barley grass.

\section{Case presentation}

\section{Case 1}

A 4-year-old boy was referred to our hospital with a 7day long history of awn aspiration. On admission, chest $\mathrm{X}$-ray, esophagogram and direct laryngoscopy were performed with negative results. Despite antibiotic therapy (amoxicillin + clavulanic acid) fever developed after 6 days with elevated C-reactive protein (CRP) $(38 \mathrm{mg} / \mathrm{L})$, and chest radiography showed atelectasis with pneumonia of the right lower lobe. During bronchoscopy no sign of a foreign body was found, and according to bacteriological culturing of bronchial lavage, antibiotic therapy was completed with netilmycin. On the ninth day of aspiration CRP was $99 \mathrm{mg} / \mathrm{L}$ and the intensity of chest pain showed no significant change. Physiotherapy, bronchodilators, expectorants, and inhalation were applied with switching of antibiotic therapy (to trimethoprim/ sulfamethoxazole and cefuroxime). One month after the incident the patient was discharged with normal blood work, and chest radiography showing decreased signs of pleuropneumonia. During the next 5 months applied conservative treatment proved ineffective for recurring symptoms. Six months after the foreign body aspiration chest computed tomography (CT) showed bronchiectasis in segments 9 and 10 of the right lung. A second bronchoscopy was carried out, showing purulent secretion with tiny fragments of awn which was removed from the bronchial tree of the right lower lobe. Nine months after the accident, control bronchoscopy revealed signs of inflammation in the right lower bronchi with huge amounts of secretion. Due to recurrent symptoms and confirmation of chronic pneumonia, surgery was decided. After posterolateral thoracotomy, severe adhesions were found between the chest wall and the right lower- and middle lobe, with inflamed hilar lymph nodes. Chronic inflammation and macroscopically abnormal appearance of the whole right lower lobe resulted in lobectomy.

Histopathology confirmed bronchiectasis with chronic inflammation caused by a foreign body blocking the bronchial lumen. After an uneventful postoperative period, the asymptomatic patient was discharged on the 13th postoperative day.

\section{Case 2}

A 9-year-old boy presented at our department with a 6day long history of awn inhalation. At the time of the accident, leading symptoms involved coughing and vomiting. Fragments of awn had also been found in his vomit and stool. After 2 days, fever and chest pain developed, thus chest X-ray was performed in a county hospital showing no apparent abnormalities. Despite having been started on amoxicillin + clavulanic acid and azithromycin, intensity of the right sided chest pain increased. Blood count showed leucocytosis $\left(14,76 \times 10^{6} /\right.$ $\mu \mathrm{L})$ with neutrophil predominance, and elevated CRP $(99,4 \mathrm{mg} / \mathrm{L})$. On the sixth day of aspiration repeated chest X-ray revealed right sided infiltration with pleural effusion. Rigid bronchoscopy was performed under general anaesthesia without any endobronchial pathology detected. Bronchial fluid was collected with negative bacteriological results. During an observational period, antibiotic therapy was completed with clindamycin, after which symptoms and blood markers improved on the sixteenth day (white blood cell: $10,000 \times 10^{6} / \mu \mathrm{L}$ without left shift, CRP: $19,77 \mathrm{mg} / \mathrm{L}$ ). Regular chest ultrasound and X-ray confirmed regression of infiltration and effusion, however 16 days later a round shaped lesion with possible abscess formation was detected at the site of the right lower lobe. Chest computed tomography showed a $41 \times 20 \mathrm{~mm}$ area with decreased air content in segment 6 of the right lung, involving the pleura (Fig. 1).

Surgery was indicated based on the history of awn inhalation, localized lung abscess with pleural effusion, and the known course of awn aspiration, potentially leading to the involvement of intrathoracic organs, and perforation through the chest wall. Focal adhesions between the right lower lobe and the diaphragm were found during posterolateral thoracotomy, and successful removal of a 4-cm-long awn particle from the pleura and the abscess wall around segment 6 was carried out (Figs. 2 and 3). Possible presence of a residual foreign body could not have been excluded, thus surgical

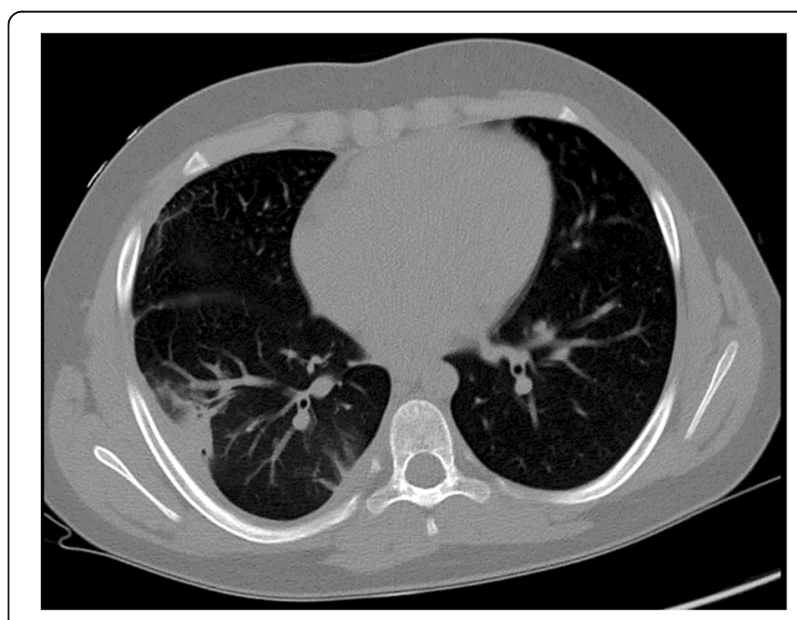

Fig. 1 Computed tomography picture of pleuropneumonia in Case 2 


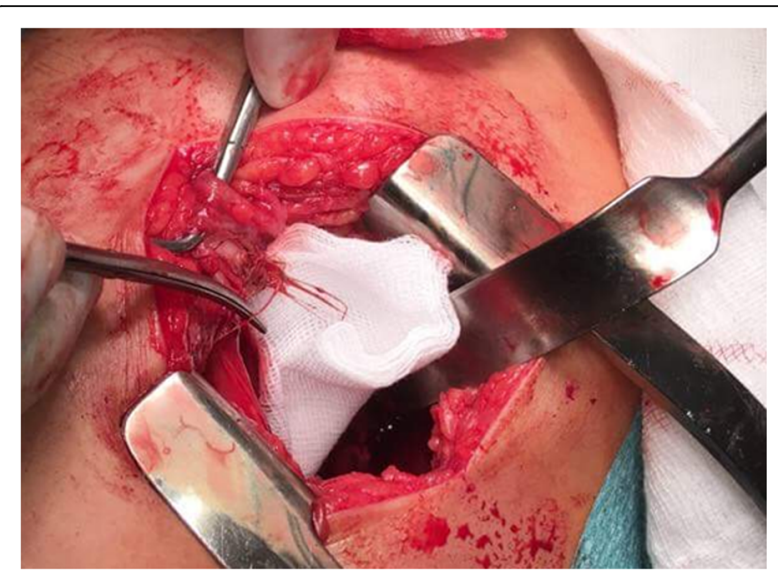

Fig. 2 Intraoperative picture of aspirated awn in Case 2

resection became inevitable. Segmentectomy was performed due to localized inflammation in segment 6 on CT. Previously described symptoms were relieved after surgery, and follow-up chest radiography showed no signs of the former abscess. The patient was discharged on the 8th postoperative day. Histology confirmed the diagnosis of a chronic granulomatous inflammation resulting from aspiration.

\section{Discussion and conclusion}

Children like to take pieces of toys or food into their mouths and keep them inside while running and playing, so when they fall, they easily aspirate them. This worldwide phenomenon is well- known, however inhalation of grass head is extremely rare. The difference between inhalation of grass inflorescence, or other foreign bodies is mainly due to their shape. A smooth, round object merely overlies the mucosa, however, grass head with its several spikes can migrate towards the periphery. Historically, Chevalier Jackson (1952) was the first to classify

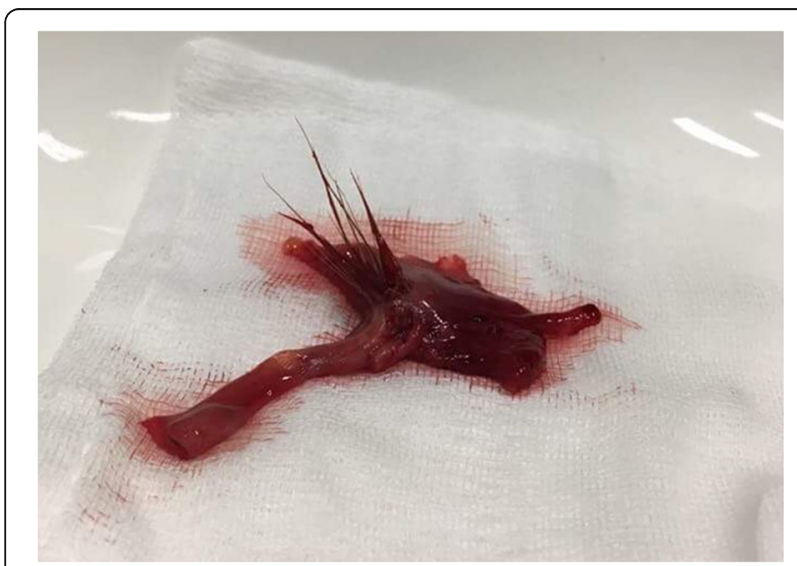

Fig. 3 Removed awn specimen in Case 2 with its several spikes, making a unidirectional migration towards the periphery grass inflorescences into two different types based on their structure. A small proportion of the grass called the "lodging" type, remains in the respiratory tract and causes pneumonitis. However, the majority, called "extrusive" type travel to the periphery of the lung. Migration continues with each coughing or respiratory action until the grass head finally penetrates through the lung and chest wall, and extrudes spontaneously [1, 6-8]. Immediate bronchoscopy may diagnose some of the "lodging" type heads in a major bronchus [9], but the majority, including the "extrusive" type, rapidly migrate deep beyond the reach of the bronchoscope.

After a few days, as the grass head travels continuously towards the periphery of the lung, initial signs and symptoms may disappear. The following asymptomatic period, with negative bronchoscopy, may create a false sense of security in physicians and parents alike. However, negative bronchoscopy or improved inflammatory markers do not exclude the presence of a bronchial grass head.

Aspiration of grass head is so rare phenomenon, that only few cases were reported in children, and most physicians has limited experience with them. With our two cases we provide diagnostic and management steps to reduce damage and to prevent developing complications.

Reviewing the literature for grass head aspiration in children, the most frequent notated outcomes caused by the grass head migration are chest wall abscess, bronchopleural cutaneous fistula and extrusion of grass head through the chest wall [6-8], pneumothorax [2], pneumomediastinum, recurrent haemoptysis, pleural effusion, bronchiectasis [4], empyema, or osteomyelitis of the rib [1], brain abscess or coexisting acute abdomen [5, 8].

Literary data is consistent, that all the cases with suspicion of a grass head aspiration should immediately be referred for bronchoscopy $[1,3,6,9]$. However, the removal can only be accomplished before peripheral migration [9]. Due to the anatomical structure of the main bronchi, an aspirated foreign body (including grass heads) is most likely present in the right lower bronchial tree, therefore examination of the right lower lobe during bronchoscopy should be emphasised. According to the revised literature, compared to only 1 left sided case, 15 cases showed inhalation into the right lower lobe [19]. Both of our cases showed grass heads in the right lower lobe.

According to the aforementioned rapid migration negative bronchoscopic result do not exclude the presence of bronchial grass head, thus symptomless child with improved inflammatory markers should be followed up thoroughly. Regular chest ultrasound and X-ray is strongly recommended to recognise inflammation and also potential late-onset, life-threatening complications in time. If the examinations show (localising) inflammation computed 
tomography can be a useful diagnostic tool in identifying the foreign body, and revealing complications. In our cases despite the fact, that both of our patients showed improvement of symptoms, computed tomographic examinations detected bronchiectasis in Case 1 and early stage abscess formation in Case 2, 6 months and 32 days after the aspiration, respectively, suggesting the presence of a foreign body.

Literature provides no exact protocol on "wait-and-see" or surgery. The majority of data state that delayed treatment can be potentially life-endangering and also suggest to perform lobectomy. In order to prevent the above mentioned complications we agree on early surgical exploration of the involved lung. The optimal time for surgical intervention can be determinated by signs of localised inflammation seen on chest X-ray or CT. Despite the fact that pulmonary inflammation may temporarily improve or even vanish, a surgical management should be strongly considered to prevent life-threatening, late complications.

During the first case, 6 months after aspiration, typical features of bronchiectasis were seen on chest X-ray, while in the second case, 32 days after aspiration, an abscess was primarily detected, with successful surgical removal in both cases.

During the first case, due to late diagnosis and extensive pulmonary inflammation, right inferior lobectomy had to be carried out. In the second case, due to localised inflammatory signs, resection of the right 6th segment was satisfactory. According to literature data, lobectomy is most frequently preferred for removal of grass heads $[1,3,4,9]$, with no previous publications of segmentectomy in case of children.

In conclusion we declare that the diagnosis of suspected grass head inhalation may lead to difficulties due to its peculiar shape and behaviour. Negative bronchoscopic result and improved inflammatory markers do not exclude the presence of bronchial grass head, thus symptomless child should be followed up thoroughly to recognise late complications in time. Regular diagnostic steps (such as chest ultrasound or X-ray) should be performed to localise inflammation. Chest CT maybe useful to confirm the diagnosis and identify the position of the foreign body. Surgical removal is opted when the grass head states peripheral, and localised inflammation evolves but before severe complications develop. In case that awn is found in a completely localized inflammation site or abscess, anatomical segmentectomy with the affected bronchus may be the preferred choice. In case of extended inflammation and abscess, or in obscure conditions, lobectomy may be required.

Abbreviations

CRP: C-reactive protein; CT: Computed tomography

\section{Acknowledgements}

Not applicable.

\section{Authors' contributions}

All authors took a significant part in the work. AR participated in collecting and interpreting of data and drafting the manuscript. TK and ZN lectured and helped to design the manuscript. KK and TN participated in acquisition of data and contributed to the writing of the manuscript. AO participated in drafting and lecture of the manuscript. JF participated in lecture of the manuscript, coordination of scientific work and final approval of the manuscript. All the authors have read and approved the manuscript of "Surgical treatment of awn aspiration causing bronchopleural fistula and bronchiectasis: Case reports".

\section{Funding}

The authors declare that they have no funding.

\section{Availability of data and materials}

The datasets used and/or analysed during the current study available from the corresponding author on reasonable request.

\section{Ethics approval and consent to participate}

The Human Investigation Review Board of University of Szeged accepted to collect and use retrospective data in our study. It is attached as

Supplementary Material.

\section{Consent for publication}

The Human Investigation Review Board of the University agreed to use data searching in our medical system retrospectively, and we kept both patients anonymity. Furthermore we received informed consent from the first patient, and also from the second (underaged) patient's parent.

\section{Competing interests}

The authors declare that they have no competing interests.

\section{Author details}

${ }^{1}$ Division of Pediatric Surgery, Department of Pediatrics, University of Szeged, 14-15. Korányi Avenue, Szeged 6725, Hungary. ${ }^{2}$ Division of Pediatric Pulmonology, Department of Pediatrics, University of Szeged, Szeged, Hungary. ${ }^{3}$ Division of Thoracic Surgery, Department of Surgery, University of Szeged, Szeged, Hungary.

Received: 20 July 2019 Accepted: 10 October 2019

Published online: 22 October 2019

\section{References}

1. Maayan C, Avital A, Elpeleg ON, et al. Complications following oat head aspiration. Pediatr Pulmonol. 1993;15(1):52-4. https://doi.org/10.1002/ppul. 1950150109.

2. Newson TP, Parshuram CS, Berkowitz RG, et al. Tension pneumothorax secondary to grass head aspiration. Pediatr Emerg Care. 1998;14(4):287-9. https://doi.org/10.1097/00006565-199808000-00013.

3. Hilman BC, Kurzweg FT, McCook WW, et al. Foreign body aspiration of grass inflorescences as a cause of hemoptysis. Chest. 1980;78(2):306-9. https://doi. org/10.1378/chest.78.2.306

4. Başok $O$, Yaldiz $S$, Kilinçer L. Bronchiectasis resulting from aspirated grass inflorescences. Scand Cardiovasc J. 1997;31(3):157-9. https://doi.org/10.3109/ 14017439709058086.

5. Spencer MJ, Millet VE, Dudley JP, et al. Grassheads in the tracheobronchial tree: two different outcomes. Ann Otol Rhinol Laryngol. 1981;90(4 Pt 1):4068. https://doi.org/10.1177/000348948109000425.

6. Kanbur S, Evman S, Dogruyol T, et al. A Bronchopleurocutaneous fistula caused by unexpected foreign body aspiration: false barley (Hordeum murinum). Ann Thorac Surg. 2015;100(6):e125-7. https://doi.org/10.1016/j. athoracsur.2015.07.043.

7. Karagöz B, Köksal Y, Varan A, et al. An unusual case of grass inflorescence aspiration presenting as a chest wall tumour. Pediatr Radiol. 2006;36(5):4346. https://doi.org/10.1007/s00247-005-0088-8.

8. Dindar H, Konkan R, Cakmak M, et al. A bronchopleurocutaneous fistula caused by an unusual foreign body aspiration simulating acute abdomen. Eur J Pediatr. 1994;153(2):136-7. https://doi.org/10.1007/BF01959227. 
9. Nasr A, Forte V, Friedberg J, Langer JC. Successful bronchoscopic retrieval of Timothy grass from the airway. J Pediatr Surg. 2005;40(4):E39-41. https://doi. org/10.1016/j.jpedsurg.2005.01.028.

\section{Publisher's Note}

Springer Nature remains neutral with regard to jurisdictional claims in published maps and institutional affiliations.

Ready to submit your research? Choose BMC and benefit from:

- fast, convenient online submission

- thorough peer review by experienced researchers in your field

- rapid publication on acceptance

- support for research data, including large and complex data types

- gold Open Access which fosters wider collaboration and increased citations

- maximum visibility for your research: over $100 \mathrm{M}$ website views per year

At $\mathrm{BMC}$, research is always in progress. 


\section{STUDY}




\title{
Contemporary management strategies of blunt tracheobronchial injuries
}

\author{
Anna Rieth ${ }^{\mathrm{a}, *}$, Endre Varga ${ }^{\mathrm{b}}$, Tamás Kovács ${ }^{\mathrm{a}}$, Aurél Ottlakán ${ }^{\mathrm{c}}$, Tibor Németh ${ }^{\mathrm{c}}$, József Furák ${ }^{\mathrm{c}}$ \\ a Division of Pediatric Surgery, Department of Pediatrics, University of Szeged, Szeged, Hungary \\ ${ }^{\mathrm{b}}$ Department of Traumatology, University of Szeged, Szeged, Hungary \\ ${ }^{\mathrm{c}}$ Division of Thoracic Surgery, Department of Surgery, University of Szeged, Szeged, Hungary
}

\section{A R T I C L E I N $\mathrm{N}$ F $\mathrm{O}$}

\section{Article history:}

Accepted 9 July 2020

Available online xxx

\section{Keywords:}

Tracheobronchial injury

Airway management

Bronchus

Rupture

Blunt thoracic trauma

Bronchial injury

\begin{abstract}
A B S T R A C T
Background: Tracheobronchial injuries are rare but feasibly life-threatening conditions. A prompt diagnosis and early management can be lifesaving. Due to the unspecific symptoms and indirect radiological signs the diagnosis often delays.

Objectives: We present a short series of patients suffering from tracheobronchial airway laceration. All the three patients had blunt thoracic or neck trauma and showed early signs of tracheobronchial injury. In the first case a 44-year-old woman was crushed by a bus. Subcutaneous emphysema, pneumothorax on chest computed tomography and hypoxaemia despite of chest tube suggested the presence of an airway injury. During operation a 4-cm-long tear of the trachea and a complete transection of the right main bronchus were found. In the second case a 12-year-old girl was crossed by a truck trailer. Early signs were respiratory failure, extended subcutaneous emphysema, blood clot in the larynx, pneumothorax on both sides. Chest CT showed pneumomediastinum. During the operation a longitudinal laceration was found separating the two main bronchi at the bifurcation. In the third case a 9-year-old boy was injured in a car accident, when the seat-belt crossed his neck. Spreading subcutaneous emphysema, pneumomediastinum and an overinflated endotracheal tube's cuff were found on CT. A completely transected trachea between the first and second tracheal rings was found. All three patients required fast intubation and bronchoscopic examination to confirm the diagnosis, and to identify the site of lacerations. All the patients underwent primary reconstruction and recovered successfully.

Conclusions: In case of suspected tracheobronchial injury, a high index of suspicion is required for early diagnosis. Most commonly respiratory distress, subcutaneous emphysema and pneumothorax are found on physical examination. Prompt intubation below the site of the injury and early laryngo- or bronchoscopic examination have priority, as we did in our cases. A primary anastomosis is required with minimal resection during urgent operation. A better outcome is to be expected when extubation is done early after surgery. We offer ordinal steps that should be taken to lead to a prompt management and good long-term outcome based on the literature and our experiences.
\end{abstract}

(c) 2020 Published by Elsevier Ltd.

\section{Introduction}

Tracheobronchial injury (TBI) is an uncommon but can become a life-threatening condition, and the majority of these patients (30-80\%) still die at the scene of the accident [1,2]. Post-mortem analyses show a $2,8 \%$ incidence of TBI after blunt trauma described

\footnotetext{
This paper is part of a supplement supported by the Hungarian Trauma Society.

* Corresponding author: 14-15. Korányi Avenue, Szeged, Hungary 6725.

E-mail addresses: rieth.anna@med.u-szeged.hu (A. Rieth), office.trauma@med.uszeged.hu (E. Varga), kovacs.tamas@med.u-szeged.hu (T. Kovács), ottlakan.aurel@med.u-szeged.hu (A. Ottlakán), nemeth.tibor@med.u-szeged.hu (T. Németh), jfurak@gmail.com (J. Furák).
}

by Bertelsen and Howitz [3]. Amongst trauma patients suffering neck or chest injury who reached emergency department, TBI incidence is estimated at $0,2-8 \%[1,4,5]$. The incidence of TBI amongst children is rarer than in adults, $<0,05 \%$ of chest traumas cause airway injury, and the associated mortality is 8,7\% [6,7]. Early diagnosis is essential for patient survival. Avoidance of airway obstruction and early, successful surgical management are vital for a successful outcome. The lack of typical clinical symptoms and the various appearance of radiological signs often delay the diagnosis. For successful treatment we should keep the possibility of an airway injury in mind, and we should be aware of the symptoms and management. With the presentation of our three cases, we discuss the 
diagnosis and the treatment of the TBI located on the neck and around the bifurcation.

\section{Case series}

Case 1

A 44-year-old woman was referred to our hospital, who had been found under a bus in an accident. After being rescued she was hypoxic despite oxygen therapy, and subcutaneous emphysema was found in the jugulum. In the nearest county hospital primary survey according to ATLS (Advanced Trauma Life Support) [8] protocol was applied and computed tomography (CT) of the head, neck, thorax and abdomen and CT angiography were performed. The following injury complex were revealed: left-sided pulmonary contusion, right-sided pneumothorax, associated with the occlusion of the right subclavian artery and multiple rib fractures on both sides. The patient was still hypoxic despite of chest decompression on the right side. At this point, airway injury was expected and a double-lumen endotracheal tube (DLT) was inserted to guarantee isolated, one-lung ventilation on left side. Her respiratory parameters hardly improved (SpO2 80\% with 100\% oxygen therapy), and she was transferred to our department for further investigations. Upon arrival her circulation was unstable and required noradrenalin support, her blood pressure was high $(150 / 90 \mathrm{mmHg}$ ) but persistently reducing, and saturation was $93 \%$. Deformed and sunk right side of the bony thorax and diminished breathing sounds over the right lower lobe were detected on physical examination. Bronchoscopic examination revealed a rupture of the right main bronchus at the level of the carina. Urgent right sided posterolateral thoracotomy was performed under doublelumen tube intubation to the left bronchus. A large pneumomediastinum was found, with intact mediastinal pleura. After opening the mediastinal pleura, a $4 \mathrm{~cm}$ tear was discovered on the lower third of the membranous trachea, which was running along to the left main bronchus $1 \mathrm{~cm}$ distal to the bifurcation. In addition, the right main bronchus was almost completely separated from the carina. The rupture of the membranous part of the trachea and the left mainstem bronchus was reconstructed with interrupted 3-0 absorbable sutures, and the right mainstem bronchus was sutured to the carina with interrupted sutures. The anastomosis was covered with a pedicle intercostal muscle flap. The subclavian arterial injury did not require urgent vascular procedure. Her recovery was uneventful. Chest tube was removed on the sixth postoperative day, and on the seventh day she was discharged from intensive care unit for rehabilitation (Figs. 1, 2).

Case 2

A 12-year-old girl was transferred to our hospital after falling down from a truck trailer over $60 \mathrm{~cm}$ high, and the trailer passed across her chest. At the scene of the accident she was in respiratory distress and had subcutaneous emphysema on her neck. Tension pneumothorax was suspected, therefore right-sided decompression by a needle and endotracheal intubation was accomplished at the scene. During intubation blood clot was found in the larynx. On presentation at our hospital an extended emphysema on the neck and thorax, and no breathing sounds over the left lung were detected. During ATLS management chest tubes were inserted into both sides, and her condition became stable (Fig. 3). Computed tomography of the head, neck, thorax and abdomen revealed pulmonary contusion on both sides, subcutaneous emphysema and fracture of collum chirurgicum humeri. In addition, pneumomediastinum caused by a rupture of the bifurcation was suspected. Bronchoscopy showed a deformity in the bifurcation, but its lumen was still intact. Also suspicion of a tear on the posterior wall of the

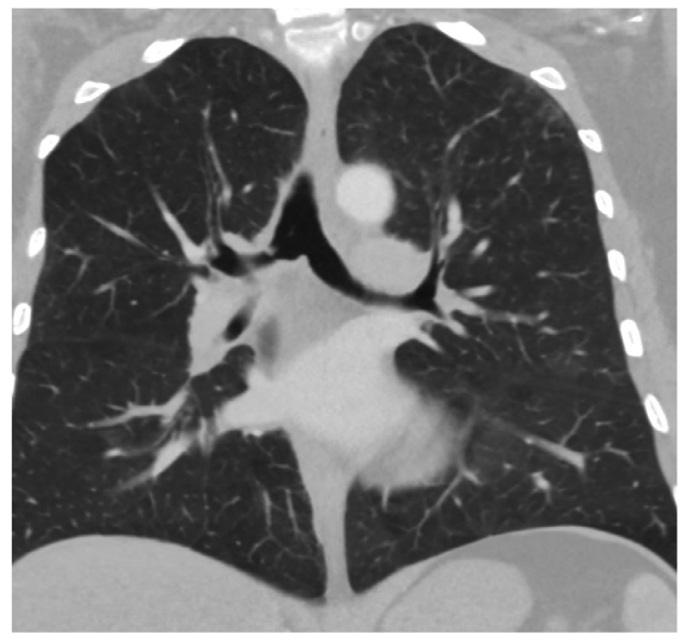

Fig. 1. Control chest CT after half year in Case 1.

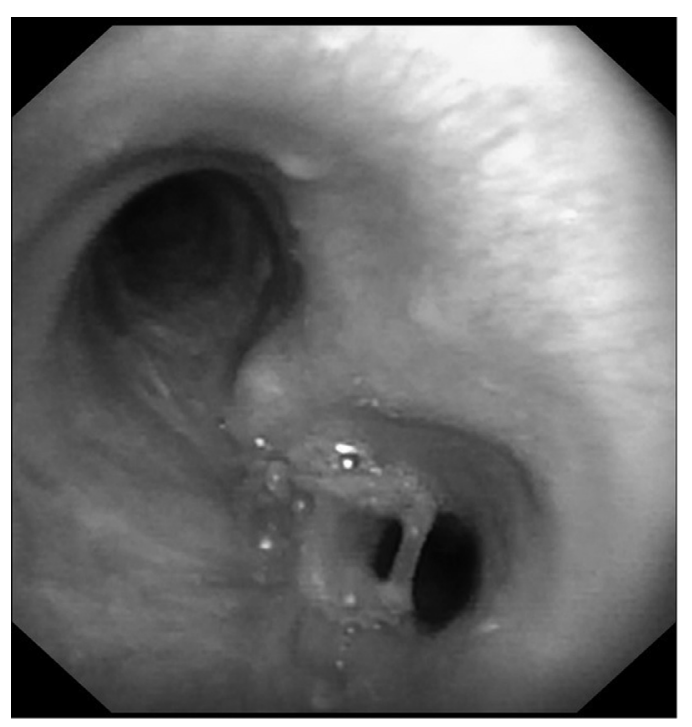

Fig. 2. Bronchoscopy shows the anastomosis after half year in Case 1.

right main bronchus was found. The patient was stable, ventilation and respiratory parameters were appropriate, lungs on both sides were expanded. After two days her parameters did not tend to improve, she still required respiratory support, and a repeated bronchoscopy declared the necessity of surgery. A right sided posterolateral thoracotomy was performed on the third day with single lumen endotracheal tube. A large pneumomediastinum was found with intact mediastinal pleura. Ventilation with single lumen tube was sufficient, but when we opened the mediastinal pleura, all the ventilated air was lost. An urgent exploration was necessary: a longitudinal laceration in the midline of the trachea was running along the bifurcation - a 2-cm-long rupture on pars membranacea and also a 2-cm on pars cartilaginea, - that the two primary bronchi were separated by. After the short exploration, the endotracheal tube was placed into the right and later into the left main bronchus guiding by the operator's finger. A complete reconstruction of the rupture of the carina was performed with interrupted 3-0 absorbable sutures, and the suture line was covered with a pedicle intercostal muscle flap to separate from the oesophagus. After an uneventful recovery chest tubes were removed after 3 days, and she was discharged on the 11th postoperative day. 


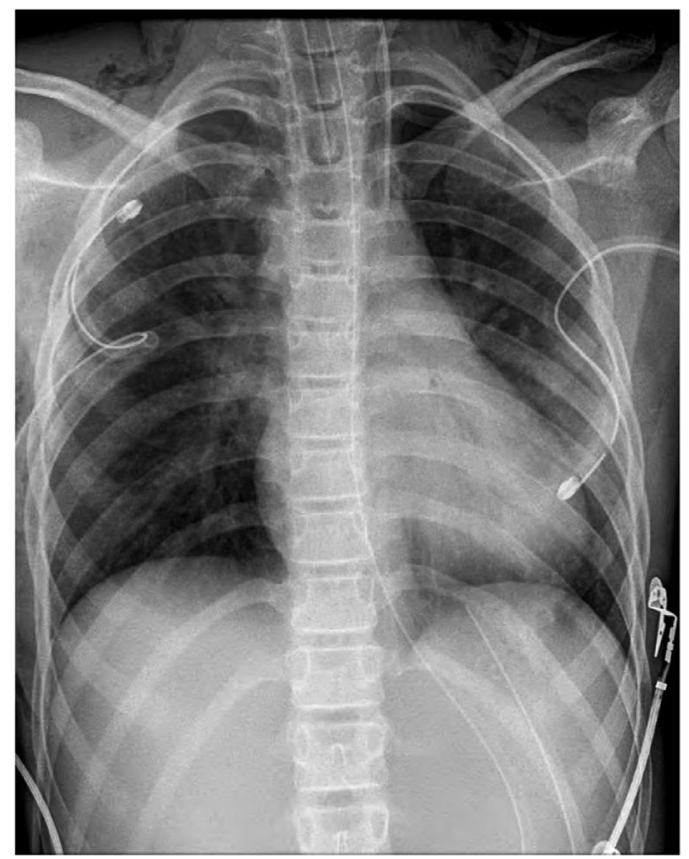

Fig. 3. Preoperative chest film with subcutaneous emphysema in Case 2 .

Case 3

A 9-year old boy was referred to the emergency room after injured as a passenger in a car accident. The car was rolled over and crushed into a tree. At the scene of the accident the child coughed some blood up, soon after he needed resuscitation, which was successful. Intubation and left thoracotomy were applied before transporting. Arriving to our department primary survey began according to ATLS protocol. On physical examination, a contusion sign was found over his neck certainly caused by the safety seat belt. He was stable and his ventilation was satisfying, therefore CT scan was performed. It revealed an extremely spreading subcutaneous emphysema starting from the deep cervical region and travelled through the wall of the thorax and abdomen. A small amount of pneumomediastinum was also discovered, but there was no sign of pneumothorax. It could be seen that the tracheal tube's cuff was over-inflated (Fig. 4). Associated injuries were the followings: severe cerebral oedema and hypoxic brain injury, left tibial fracture and right-sided pulmonary contusion. Based on the history of a direct cervical trauma accompanied by deep cervical emphysema spreading to the abdomen, the possibility of tracheal laceration was considered. Otolaryngologist examined and excluded the presence of tracheal rupture above and below the site of the endotracheal tube's cuff. During surgery a complete transection between the first and second tracheal rings was found, and the ends of the ruptured parts were located $3 \mathrm{~cm}$ apart from each other. The cuff was lying between the two separated tracheal part. The tube's distal half was ended in the lower trachea and provided satisfying ventilation (Fig. 5). Primary closure was done with tensionfree interrupted sutures, and drain was left for two days. By using a chin-to-chest stitch we ensured neck flexion and tension-free anastomosis. Due to the severe brain damage and pulmonary contusion extubation could not be managed in the operating room, and the patient required long-term ventilatory support. Laryngeal oedema and tracheal stenosis developed; thus tracheostomy was done and patient received steroid. Successful extubation was managed on the 11th postoperative day, and tracheostomy cannula was removed after one week, without any sign of stenosis.
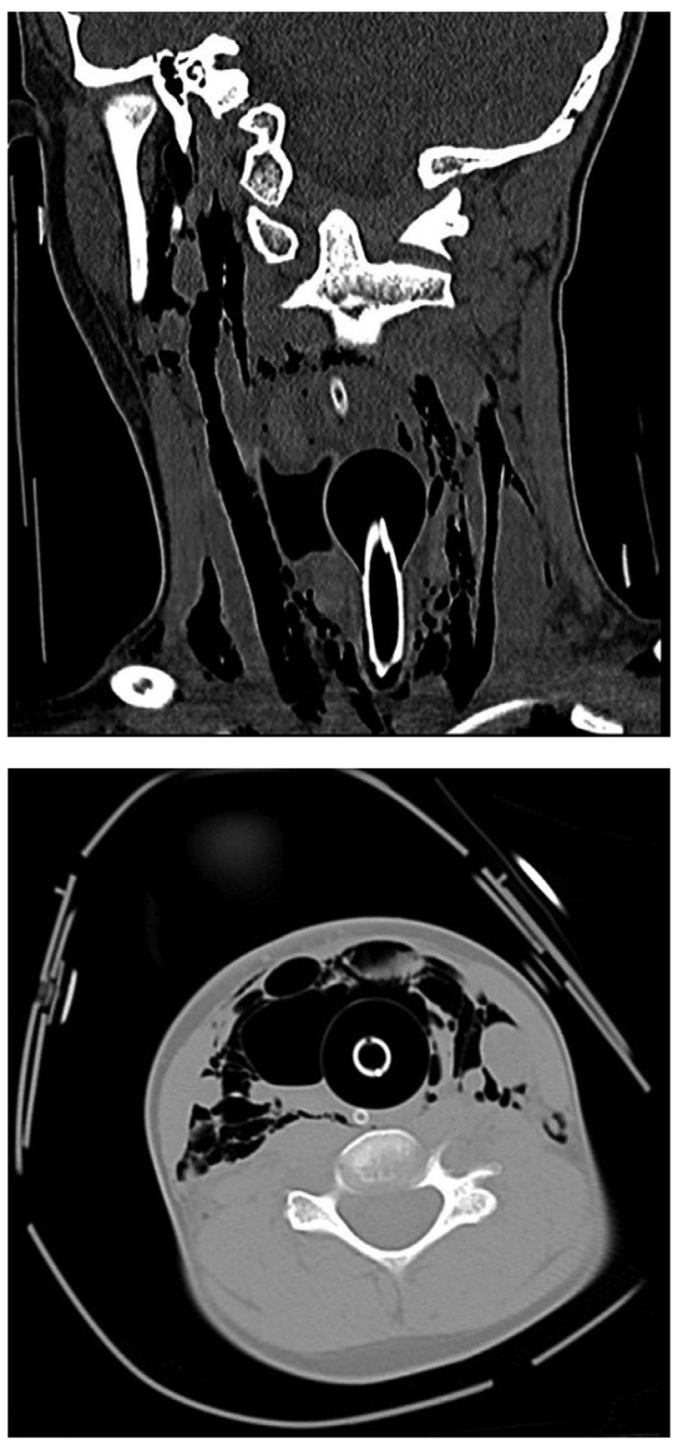

Fig. 4. Overinflated endotracheal tube's cuff and deep cervical emphysema seen on MDCT in Case 3. While the distal part is intact, the proximal part of the trachea cannot be detected.

\section{Discussion}

\section{Epidemiology of TBI}

Injury of tracheobronchial tree occurs by iatrogenic or traumatic cause, which includes blunt or penetrating injury on the neck and thorax. The majority of patients having TBI involve in a highvelocity car or a motor accident. Other injuries include falling from height, crush trauma or pedestrian accidents [5,9]. Blunt trauma is responsible for TBI approximately in $94 \%$ of cases in children, while penetrating injuries are more frequent in adults [6]. All of our cases caused by blunt traumas.

Trachea is more vulnerable at the cervical region. Proximal or middle third tracheal injury commonly appears in penetrating trauma and more likely to be identified and repaired in an early stage. Blunt traumas on neck are mostly occurred due to direct injury or sudden hyperextension. Typical example for direct force is when the trachea is pushed to the oesophagus and the stable vertebral body by an elevated seatbelt, as it was seen in our third case. Based on this mechanism, it can be declared that tracheal rupture tends to be at the exact level of the direct trauma and 

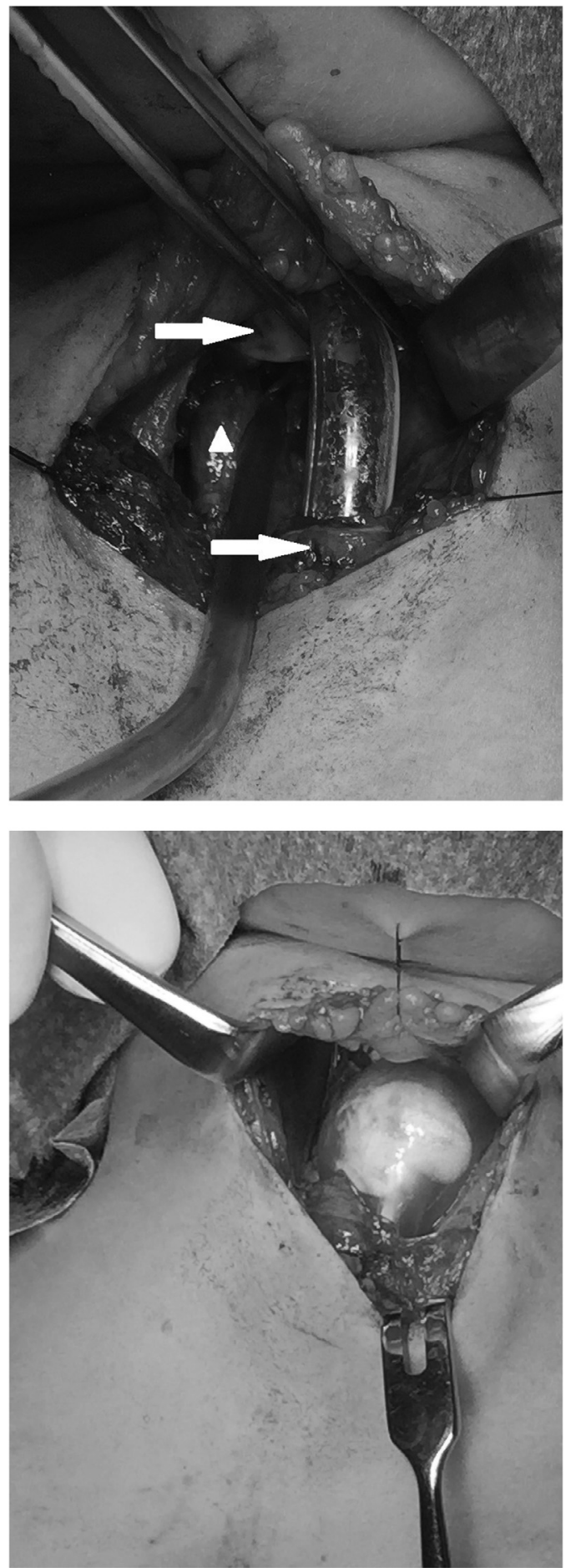

Fig. 5. Intraoperative picture in Case 3. Ruptured tracheal parts are marked by arrows. Triangle shows intact oesophagus.

often associated with oesophageal injury. During compression the sudden increased intratracheal pressure may lead to tracheal tear, paramedian vertical fracture of the larynx or trachea, or even to complete laryngo-tracheal separation. Rapid hyperextension mostly appears when a vehicle is hit from the back, usually following by smashing of the neck into the dash-board, as it is called dashboard tracheal injury.

The paper of Kirsh et al. declared three different types of mechanism causing intrathoracic TBI in blunt traumas [10]. The most common mechanism is sudden anteroposterior compression, when these forces lead to lateral separation in the carina. In the first two cases of ours TBI developed due to the abovementioned mechanism, when the vehicles caused an anteroposterior compression on the chest. The second type includes compression on the chest while the glottis is closed, causing abruptly increased airway pressure. The third way is based on the relative fixation at the level of bifurcation and cricoid cartilage while the lungs are more mobile in the pleural space. In this state an acceleration-deceleration mechanism can cause a shearing force and disruption of the airway. These explain that bronchial injuries mostly occur in motor vehicle accidents, caused by flexion-extension forces.

\section{Location, size and classification of TBI}

Lesions can be distinguished as longitudinal or transversal, and single or complex, when more than one lesions exist. Transverse tears can be partial or complete. In partial tears the airway may remain intact and prevents air-leakage and causes only mild symptoms leading to a delayed diagnosis. A complete airway rupture is generally life-threatening and often associated with severe concomitant injuries.

Upper airway damages can be classified as supraglottic, transglottic or subglottic injuries based on the site of the laceration. In generally the membranous part of the trachea is the weakest point and most likely for disruption, compared with the anterior and lateral wall which are strengthen by the U-shaped tracheal rings. Therefore, the anterior trachea is mostly injured in penetrating injuries, while the posterior wall is mainly affected in blunt traumas [4].

Literature data is consistent, that $75-90 \%$ of TBIs in blunt trauma are located within $2-3 \mathrm{~cm}$ of the carina and $60 \%$ of them are within $1 \mathrm{~cm}[1,2,9,11]$.

The majority of the literature states that the main bronchi are frequently injured (66-85\%), especially on the right side (27-61\%) $[2,9,12,13,14,15]$. Compared with it the cervical trachea (4-19\%), distal thoracic trachea (22\%), left proximal main bronchus (17-32\%) or lobar orifices are less frequently affected (14-16\%) [7,12,13].

The abovementioned right sided predominance is probably known as the right bronchus is more fixed in the thorax, but less protected by surrounding vascular entities than the left one. The right side has also a heavier connecting lung parenchyma on a shorter bronchus [11]. In addition, the right bronchial tree lays close to the thoracic vertebrae, and has the risk to be compressed on the spine during an accident. These anatomy specialities explain that right-sided lesions are more frequent and have higher mortality rate than left-sided. In comparison, the diagnosis tends to be delayed in left-sided cases, due to the abovementioned protective adjacent structures [2].

There are only few data in the literature about morphological classification and related treatment options in TBI patients. For laryngotracheal ruptures Schaefer and Fuhrman defined a system based on the depth of the lesion [14]. In Group I. and II. minor endolaryngeal laceration or mucosal oedema and haematoma appear, and nondisplaced fracture is in Group II. Massive oedema, displaced fracture and vocal cord paralysis defined as Group III. While in Group IV. unstable fracture or more than two fracture lines are present, in Group V. a complete laryngeal separation appears. This study recommends conservative therapy in Group I., tracheostomy in II., and emergent tracheostomy and surgical exploration in Group III., IV. and V.

Another method described by Cardillo et al. declares different levels of laceration and offers a key to decide between conservative and surgical treatment [16]. Level I and II is defined as an incomplete laceration in the layers of tracheal wall. Level III is a complete lesion in all muscular layers of the trachea with herniation of the oesophagus or mediastinal tissue. Cardillo's prospective 
study advises a non-surgical management for Level I, II and III/A, where 29 adult patients with a lesion in these levels were successfully treated with fibrin glue. The presence of oesophageal injury or mediastinitis (Level III/B) determines the need of a prompt surgical treatment. Although this classification method is originally used in postintubation tracheobronchial laceration, some authors promote this method in the management of traumatic airway injuries as well.

\section{Diagnosis}

\section{Symptoms}

Tracheobronchial injuries are difficult to diagnose due to the unspecific symptoms on physical examination and signs in radiology. The presence of concomitant injuries can obscure the symptoms of airway lesion and leads to a delayed diagnosis and early fatal outcome [1]. Therefore, it cannot be overemphasised that a high index of suspicion is the most important clue for prompt diagnosis. TBI has a delayed diagnosis in $25 \%$ to $68 \%$ of patients [11]. Sometimes days or even weeks pass after the trauma until the correct diagnosis is revealed.

The most common symptoms are tachypnoea, respiratory distress (59-100\%), and haemoptysis (14-74\%). Dyspnoea and stridor can be an early sign of tracheal stenosis. Cervical trauma leads to hoarseness or dysphonia causing by laryngeal fracture, vocal cord tears or recurrent laryngeal nerve injury. Nevertheless, subcutaneous emphysema is the classic hallmark (35-87\%) of TBI. Extremely spreading subcutaneous emphysema could even reach the abdomen and lower extremity skin [13]. When a progressive emphysema following blunt trauma occurs, the possibility of TBI should be always considered [1,2,11], as it was in our third case. Spreading subcutaneous emphysema which stops after intubation verifies the diagnosis. We should bear it in mind that emphysema and pneumomediastinum may not appear initially [11]. Even in patients with complete transection, adequate lung ventilation can be managed due to the surrounding tissue which covers the separated fragments and restrain air-leakage.

Lesion in the lower airway causes pneumothorax in $17 \%-72 \%$ of patients, as it was presented in our first two cases. Airway injury generally maintains a massive air-leak through chest drainage and restrains the re-expansion of the lung, which should always alert the clinician to the possibility of TBI $[1,4,11,17]$, as it happened in our first case. On the other hand, a complete transection may lead to occlusion in the airway caused by the surrounding soft tissue, which prevents developing pneumothorax.

Another sign is due to the mediastinal air-filled tissue causing a rasping rumour, called Hamman's sign. It is detected synchronous with the heartbeat on auscultation [1].

Up to $40 \%-100 \%$ of patients with blunt chest trauma are associated with injuries of the abdomen, head or orthopaedic structures [5]. For instance, the most frequent coexistent injuries in cervical region are oesophageal injuries, hemopneumothorax, carotid artery or jugular venous injuries, recurrent laryngeal injuries, cervical spine and larynx injuries. Intrathoracic blunt trauma often involves the great vessels, oesophagus and heart, and causes pulmonary contusion, rib or burst vertebral fracture.

\section{Radiology}

Various indirect signs of an airway lesion can be detected by radiology routinely performed in acute emergency situation; however direct, obvious findings are rarely occurred. Since the introduction of Advanced Trauma Life Support (ATLS) patients with TBI have a lower mortality rate [2]. Primary survey includes eFAST examination (Extended Focused Assessment with Sonography in
Trauma) recommended by ATLS 10th edition [8]. It has a high sensitivity for detecting the presence of pneumo- or hemothorax. The transducer should be placed in the superior pectoral region either on the left and right side, and both $\mathrm{M}$ and $\mathrm{B}$ mode should be applied. Subcutaneous emphysema may add a limitation, but can suggest the presence of tracheobronchial injury.

If endotracheal intubation is successfully managed, but persistent hypoxaemia without pneumothorax is seen on eFAST examination, we should keep an attention of airway injury [17]. On chest $\mathrm{X}$-ray (CXR) the three typical signs of TBI are subcutaneous emphysema, pneumothorax and pneumomediastinum $[1,2,6,12]$. If subcutaneous emphysema is accompanied by the hyoid bone's elevation above $\mathrm{C} 3$ in the neck the possibility of an upper airway transection and rising of the larynx is high. Endotracheal tube presenting external from the airway or an over-inflated endotracheal tube cuff are additional radiologic fidings $[1,9]$. Other indirect signs that may appear is tracheal deformity, discontinuity of the tracheal or bronchial air column. Almost the only direct and pathognomic CXR sign of TBI is the "fallen lung sign". This means that complete transection of the bronchi makes the separated lung to collapse laterally and posteriorly, while in other cases of pneumothorax lung tends to get collapsed to the hilum $[5,9,13]$.

These aforementioned diagnostic tools help the clinicians to suspect airway injury. At this point Bagga et al. defined the criterion that may signify the need of an urgent chest computed tomography: 1) hypoxaemia without pneumothorax after endotracheal intubation, 2) massive air leak after tube thoracotomy and persistent pneumothorax, 3) progressive subcutaneous emphysema and pneumomediastinum [17].

Multi-slice detector computed tomography (MDCT) is superior to traumatic radiographic methods, it can identify and localize the lesion and detect concomitant injuries as well. Unfortunately, direct visualization of tracheobronchial disruption such as complete transection, tracheal ring fracture or fallen lung sign is less reliable. In case of upper airway injury CT scan may identify paratracheal air, deep cervical emphysema or pneumomediastinum. In case of patients with lower airway injury CT can reveal the following findings: pneumomediastinum, mediastinitis, mediastinal haematoma, focal intimal flap in the lumen, bronchial stenosis or obstruction $[5,12,13,17,18]$. Although direct signs are less common, the presence of tracheobronchial interstitial air or gas dispersion around the lesion are remarkable, and should be an alert sign. The sensitivity of CT imaging is seen in up to $71-100 \%[1,5,17,18]$. However there are still some false negative results due to circumferential oedema and haemorrhage, a negative $\mathrm{CT}$ does not exclude the presence of a TBI $[7,14]$.

In our first case $\mathrm{CT}$ revealed only a right-sided pneumothorax. The patient had subcutaneous emphysema, and even after chest drainage she was still hypoxic, thus that was which strongly suggested the presence of TBI. In Case 2 respiratory distress, subcutaneous emphysema, blood clot in the larynx were found, and pneumothorax on both sides were managed by chest tubes. CT revealed pneumomediastinum, which together lead to a suspicion of TBI. In the third case contusion on the neck was discovered on physical examination. CT showed extremely spreading subcutaneous emphysema and pneumomediastinum as indirect signs, and a real direct sign of TBI was also revealed as the endotracheal tube's cuff was overinflated and presented external from the tracheal wall. All our three patients required bronchoscopic examination to confirm the diagnosis, and to identify the site of lacerations.

After CT an additional three-dimensional reconstruction or virtual bronchoscopy should be considered as a valuable help in diagnosis $[15,18]$. Oesophageal injuries are frequently associated, especially after direct trauma on neck, when trachea is smashed onto the oesophagus and cervical vertebral bodies. Contrast esophagogram can supplement the diagnosis and reveals a posterior tra- 
cheal wall rupture [8]. In case of a complete tracheal rupture, we should always search for concomitant injury of the oesophagus as well.

\section{Endoscopic examination}

Laryngoscopy and bronchoscopy are crucial part of diagnostic procedure. However, the CT has several advantages, these still remain the "gold standard" diagnostic tools. Laryngoscopy should be performed by otolaryngologist in cervical trauma or in suspicion of a laryngeal injury. It should be applied preferably with fibreoptic laryngo- or bronchoscopy through endotracheal tube. It is quick, easy and could be applied even in case of cervical spine injury [11]. All patients with suspicion of airway injury should undergo this examination as early as possible $[2,4,5,17]$. The most common findings include tear of the wall, blood clot filling the airway and collapsed lumen distal from the haematoma [1]. In some mild cases with simple mucosal laceration a small amount of blood could be the only sign for clinicians. If the endotracheal tube lays over the laceration part the lesion can be missed. For this reason, some of the patients are diagnosed only after extubation. If having a high suspicion of tracheal injury, it is better to deflate the tube's cuff and manipulate with the tube during bronchoscopy.

In Case 1 bronchoscopic examination revealed a rupture of the right main bronchus at the level of the carina. It was defined in Cardillo's classification [16] as a Level III/B laceration, and needed prompt surgical treatment, as having a high risk of developing mediastinitis. We did urgent operation and found a $4 \mathrm{~cm}$ long tear on the membranous trachea and a complete transection of the right main bronchus. In the second case bronchoscopy showed deformation in the bifurcation, but its lumen was intact, which was classified as Level III/A laceration and could be managed either surgical or non-surgical. During operation we found a longitudinal laceration separating the two main bronchi. In the last case CT showed an overinflated tube cuff and laryngoscopic examination confirmed the suggestion of a laceration at the level of the endotracheal tube's balloon. We found a completely transected trachea between the first and second tracheal rings. It was a Level IIIB laceration by Cardillo, or a Group V. rupture by Schaefer and Fuhrman's laryngotracheal classification method, and had urgent surgical indication.

\section{Emergency airway management}

Literary data consist that the most important priority is immediate intubation in patients suffering from TBI. Intravenous paralysis should be avoided, because transected airway is possibly attached and supported only by surrounding muscle. In addition an attempt of blindly intubation may lead to a false passage external from the airway, therefore intubation under the visualization of flexible bronchoscope is preferred $[1,2,9,12]$. It is important, that the tube should bypass the injured part and the cuff should be inflated distally to avoid further disrupt, even complete transection $[1,12,19]$. Low-tidal volume or low pressures may also prevent further disruption.

Tracheostomy is rarely necessary. It is recommended in patient with severe maxillofacial trauma, unstable fractures of the face, palpable deformity over the trachea, extremely oedema or haemorrhage. Other indications include severe oedema leading to obstruction, and inability to intubation. The tracheostomy is suggested to be caudal from the level of the injury. We should be aware that in case of a complete transection, the distal part of the trachea may slip into the mediastinum [11,17]. After tracheostomy, a definitive airway repair can be managed later.

Disruptions at the site of the bifurcation may require a doublelumen tube or selective endobronchial intubation [19].
In a difficult situation the surgeon can help with his finger in tube guidance through thoracotomy wound.

\section{Surgical management}

Treatment of airway injuries should be individualized at every patient, considering comorbidities, location of the lesion and clinical presentation [4]. After safe airway management and necessary diagnostic steps, the patient should be transferred to the operating room for reconstruction as soon as possible. The most important purposes of the surgery are 1) preventing airway obstruction, 2) avoiding spontaneous healing complications (such as stenosis), 3) avoiding mediastinitis 4) stop massive air leak and improve sufficient ventilation [1].

Independently of the lesion's site, a primary reconstruction should be attempted. Proximal part of the trachea is available through a low collar incision, which ensures a good exposure of vascular or oesophageal injuries. In middle-third tracheal injury a partial sternotomy over the manubrium with or without a collar incision provides a good view. We should keep it in mind, that in case of a complete transection in the cervical trachea, the distal part can easily retract into the mediastinum, leading to severe symptoms and making more difficult to approach it.

Distal third of the trachea, bifurcation and bronchi can be reached via a left or right thoracotomy in the 4-5TH intercostal space [1]. The access of the left main bronchus has some difficulties and seldom requires mobilisation of the aorta and division of the ligamentum arteriosum [2]. In some selected cases a median sternotomy can be an alternative approaching method. We mostly use a right sided thoracotomy if intrathoracic trachea, carina, right main bronchus or the proximal half of the left main stem bronchus injured.

For small transversal tears interrupted sutures are recommended, where the knots should lie outside the lumen to reduce the postoperative irritating and cough, and to avoid late stenosis. Longitudinal lacerations can be accomplished by continuous running suture. Larger disruption or complete transection requires refreshing on the damaged edges prior to primary end-to-end anastomosis $[1,13]$. Excessive airway mobilization should be avoided in order to prevent devascularisation, which may lead to late sequels, as dehiscence or stenosis. As far as possible primary repair of the carina should be performed and its resection should be avoided. If a resection is inevitable only an up to $3-4 \mathrm{~cm}$ long section of the airway allowed to be resected $[1,5,11,20]$.

If there is an extremely wide tissue damage and a primary repair cannot be performed a tracheostomy should be done. In case of laryngocricoid or both recurrent laryngeal nerves injury a protective tracheostomy is recommended $[1,11]$. The site of the tracheostomy should be as far as possible from tracheal restoration reducing the risk of dehiscence or stenosis. When resection is inevitable a tension-free anastomosis can be provided by blunt dissection of the avascular pretracheal plane. Flexion in the neck can be performed also for the purpose of a tension-free anastomosis for some days. For intrathoracic tension-free anastomosis, an opening on the pericardium or division of the inferior pulmonary ligaments can be performed. These techniques allow a $1-2 \mathrm{~cm}$ mobilization of the airway $[1,2,11,12]$.

In case of a severe airway disruption protective tissue flap (pleura, pericardium, mediastinal fat, muscle flap) can be used to cover the anastomosis or separate the oesophagus $[1,5,13]$. Severely distorted lung parenchyma requires lung resection occasionally.

All our three patients had primary anastomosis with 3-0 interrupted absorbable sutures without any resection. Two cases with lower airway injury had a pedicle intercostal muscle flap for covering, thus we successfully avoided postoperative dehiscence. Laryn- 
gotracheal laceration needed extended mobilisation of the trachea as the separated part were $3 \mathrm{~cm}$ apart from each other.

\section{Non-surgical management}

In some selected cases conservative treatment can be considered. Stated criterion include the followings: tear should be under $2 \mathrm{~cm}$ or one-third of the diameter, the patient should be clinically stable, breaths spontaneously or requires minimal ventilator support, and there should be no sign of mediastinitis or sepsis $[1,2,11,13]$.

According to Cardillo et al. [16] who classified airway lacerations, an incomplete rupture of the muscular wall (L. I, II) or simple complete wall rupture (L. III/A) can be managed non-operatively. Surgical approach is required when complete laceration associated with mediastinitis or coexistent oesophageal injury (L. III/B) or in case of separation between the two tracheal or bronchial parts.

Conservative treatment is mostly suggested in iatrogenic cases. These patients need antibiotic therapy and drainage. Previously reported, conservatively managed largest tracheal laceration was $4 \mathrm{~cm}$ long [2].

Self-expanding metallic stent (SEMS) can be used as alternative treatment in patients who have high surgical risk or severe comorbidities. This novel method is also useful in case of late stenosis caused by granulation tissue at the site of laceration [12].

For unstable patient with ventilatory failure extracorporeal membrane oxygenation (ECMO) is a valuable possibility, successfully applied by several authors [21,22,23,24,25].

\section{Postoperative management}

Postoperative earliest extubation is recommended to minimize the local trauma which is caused by the tube or elevated endotracheal pressure $[2,9,11,15]$. After isolated airway injury extubation can be safely performed in the operating room. If mechanical ventilation is necessary, the lowest pressure should be applied, and frequent pulmonary toilet is required to remove secretion [11]. Especially patients having vocal cord paralysis need aggressive pulmonary toilet, in which a mini tracheostomy seems to be helpful to allow a direct tracheal aspiration. In every case clinician should be convinced that the tube's cuff does not overlie onto the repaired site.

When early surgery can be managed a good long-term outcome is expected. It also depends on the severity of the associated injuries, developing septic condition, the necessity of intubation and intensive care unit support. Postoperative bronchoscopy should be performed after 7 to 10 days to ensure satisfactory healing and excluding stenosis [11].

Complications develop in up to $25,8 \%$ of the patients, which includes early anastomotic dehiscence, mediastinitis or 2-6 weeks later airway stenosis [1]. The incidence of stenosis and anastomotic dehiscence is 5\%-6\% [11]. These lead to recurrent pneumonia, bronchiectasis, or finally complete obstruction [2]. Some of these patients need an airway resection and reconstruction after 3 to 6 months. Injury of the larynx or recurrent laryngeal nerves may lead to phonation problems.

Initial diagnosis of TBI can be missed in $25 \%-68 \%$ of the patients [11]. This is due to mostly the serious associated injuries which obscure the symptoms of airway lesion. In other cases, the rupture might be small enough to cause only mild symptoms. The respiratory tract heals in 1-4 weeks after injury, but stricture may appear due to granulation tissue. This stenosis can cause obstruction in the airway, leading to consequential pneumonia, bronchiectasis or atelectasis [11].

\section{Conclusions}

An algorithmic approach for surgical or non-surgical management of thoracic airway injury is offered. The most important steps to prompt primary management according to the contemporary literature are summarized (Figs. 6, 7).

When patient presents on emergency department the first step is to consider whether she or he had a trauma which can lead to airway injury (previous flexion-extension or compression forces, sign of an elevated seat-belt, blood in the vomit or sputum). The most important symptoms we should search for on physical examination include dyspnoea, respiratory distress, subcutaneous emphysema, suspected pneumothorax and contusion over the neck and thorax. Stable patient should be referred for prompt MDCT examination, and if there are signs of tracheobronchial injury (pneumomediastinum, spreading subcutaneous emphysema, persistent pneumothorax despite of tube thoracostomy), then laryngoscopy or bronchoscopy should be immediately done to localise the site of the laceration. At any time when it is necessary an intubation guiding by fiberscope is a good choice, at least when laryngoscopic/bronchoscopic examination is applied. Here we have an opportunity to perform esophagoscopy if a posterior wall disruption is suspicious and the diagnosis is not clear. If airway injury is confirmed, we should transfer the patient to the operation room as soon as possible. In some selected cases when special conditions are fulfilled conservative therapy can be a valuable alternative choice. These conditions are: tear should be under $2 \mathrm{~cm}$ or one-third of the diameter, the patient should be clinically stable, breaths spontaneously or requires minimal ventilator support, and there should be no sign of mediastinitis or sepsis. Conservative therapy should be disestablished and surgical management should be done at any time when healing process or the patient's condition is not satisfying.

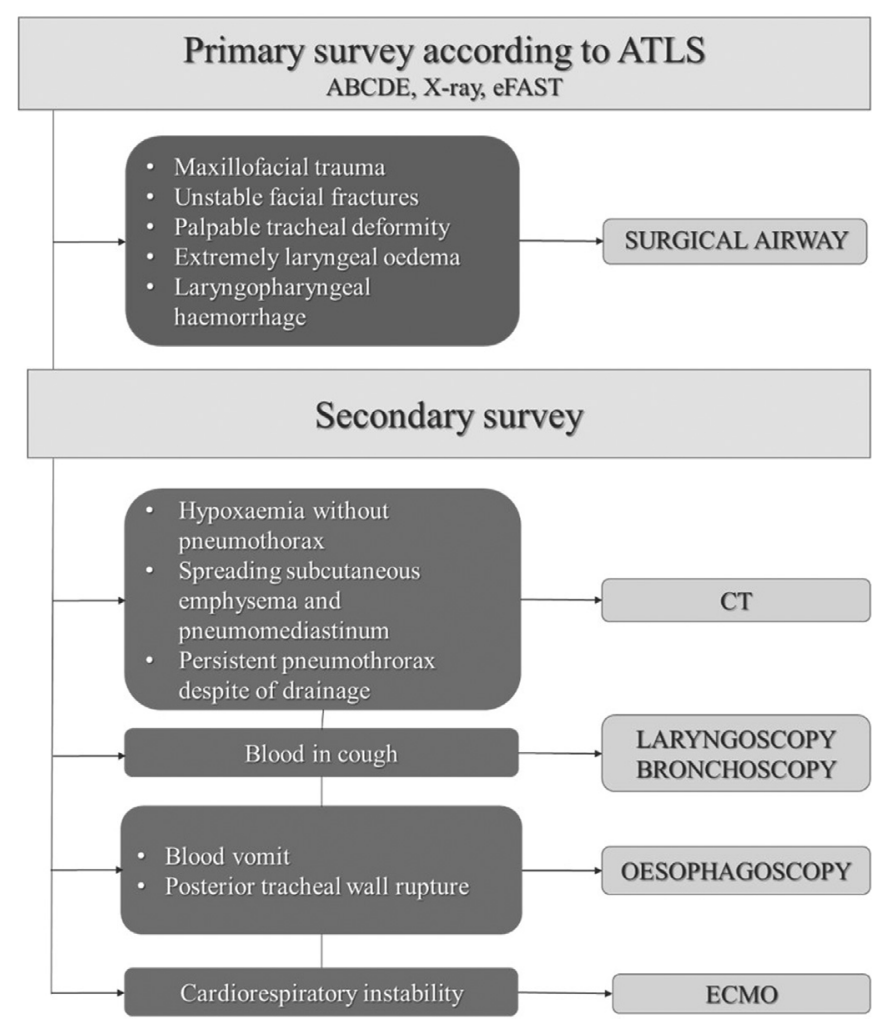

Fig. 6. Diagnostic and emergency intervention flowchart. 

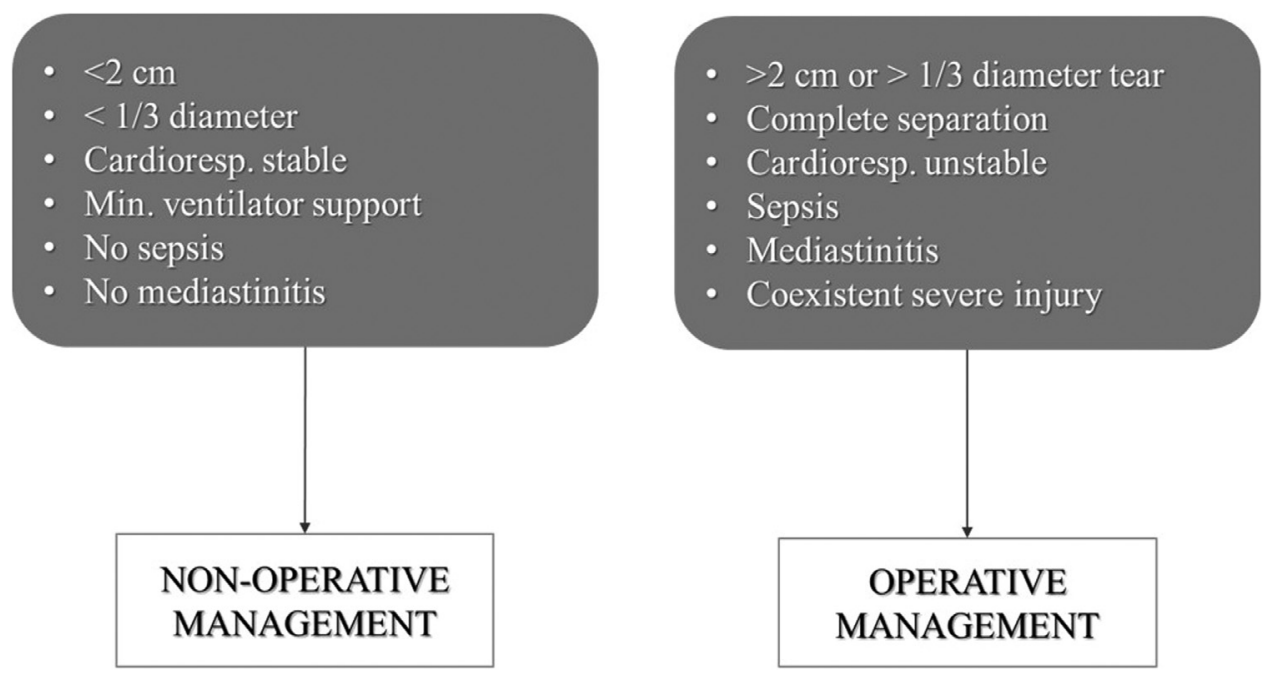

Fig. 7. Treatment flowchart of TBI.

\section{Declaration of Competing Interest}

All the authors declare that they have no conflict of interest or funding.

\section{Supplementary materials}

Supplementary material associated with this article can be found, in the online version, at doi:10.1016/j.injury.2020.07.026.

\section{References}

[1] Prokakis C, Koletsis EN, Dedeilias P, Fligou F, Filos K, Dougenis D. Airway trauma: a review on epidemiology, mechanisms of injury, diagnosis and treatment. J Cardiothorac Surg 2014;9:117 Jun 30.

[2] Kuzdzal J, Asamura H, Detterbeck F, Goldstraw P, Lerut A, Thomas P, et al.. ESTS textbook of thoracic surgery vol 2. Cracow: Medycyna Praktyczna; 2015. p. 937-43.

[3] Bertelsen S, Howitz P. Injuries of the trachea and bronchi. Thorax 1972;27(2):188-94 Mar.

[4] Gallagher JJ. Management of blunt pulmonary injury. AACN Adv Crit Care 2014;25(4):375-86 Decquiz 387-8.

[5] Welter S. Repair of tracheobronchial injuries. Thorac Surg Clin 2014;24(1):41-50 Feb.

[6] Dominguez E, Torre CDL, Sánchez AV, Hernandez F, Ortiz R, Moreno AMA, et al. Severe Tracheobronchial Injuries: our Experience. Eur J Pediatr Surg 2015;25(01):71-6 Feb.

[7] Cheng J, Cooper M, Tracy E. Clinical considerations for blunt laryngotracheal trauma in children. J Pediatr Surg 2017;52(5):874-80 May.

[8] Book. ATLS advanced trauma life support, student course manual. 10th Edition. American College of Surgeons; 2018.

[9] van Roozendaal LM, van Gool MH, Sprooten RTM, Maesen BAE, Poeze M, Hulsewé KWE, et al. Surgical treatment of bronchial rupture in blunt chest trauma: a review of literature. J Thorac Dis 2018;10(9):5576-83 Sep.

[10] Kirsh MM, Orringer MB, Behrendt DM, Sloan H. Management of tracheobronchial disruption secondary to nonpenetrating trauma. Ann Thorac Surg 1976;22(1):93-101.
[11] Altinok T, Can A. Management of Tracheobronchial Injuries. Eurasian J Med 2014;46(3):209-15 Oct.

[12] Shemmeri E, Vallières E. Blunt Tracheobronchial Trauma. Thorac Surg Clin 2018;28(3):429-34 Aug 1.

[13] Zhao Z, Zhang T, Yin X, Zhao J, Li X, Zhou Y. Update on the diagnosis and treatment of tracheal and bronchial injury. J Thorac Dis 2017:9(1):E50-6 Jan.

[14] Santiago-Rosado LM, Sigmon DF, Lewison CS. Tracheal Trauma. [Updated 2020 Apr 28]. In: StatPearls [Internet]. Treasure Island (FL): StatPearls Publishing; 2020 Jan. Available from: https://www.ncbi.nlm.nih.gov/books/NBK500015/

[15] Alassal MA, Ibrahim BM, Elsadeck N. Traumatic intrathoracic tracheobronchial injuries: a study of 78 cases. Asian Cardiovasc Thorac Ann 2014;22(7):816-23 Sep 1.

[16] Cardillo G, Carbone L, Carleo F, Batzella S, Jacono RD, Lucantoni G, et al. Tracheal lacerations after endotracheal intubation: a proposed morphological classification to guide non-surgical treatment. Eur J Cardiothorac Surg 2010:37(3):581-7 Mar:

[17] Bagga B, Kumar A, Chahal A, Gamanagatti S, Kumar S. Traumatic Airway Injuries: role of Imaging. Curr Probl Diagn Radiol. 2020 01;49(1):48-53.

[18] Newbury A, Dorfman JD, Lo HS. Imaging and Management of Thoracic Trauma. Semin Ultrasound CT MR 2018;39(4):347-54.

[19] Elgendy H, Jilani T. Successful anesthetic management in a child after traumatic rupture of left main bronchus by a single-lumen cuffed-endotracheal tube. Ann Card Anaesth 2014;17(4):292 Jan 10.

[20] Dennis BM, Bellister SA, Guillamondegui OD. Thoracic Trauma. Surg Clin North Am 2017;97(5):1047-64 Oct.

[21] Biancosino C, Krüger M, Kühn C, Zinne N, Wilhelmi M, Zeckey C, et al. First Successful Surgical Reconstruction of Bilateral Transected Main Bronchi With Extracorporeal Membrane Oxygenation Support. Ann Thorac Surg 2016;102(2):e135-7.

[22] Ryu KM, Chang SW. Heparin-free extracorporeal membrane oxygenation in a patient with severe pulmonary contusions and bronchial disruption. Clin Exp Emerg Med 2018;5(3):204-7 Apr 30.

[23] Hamilton EC, Lazar D, Tsao K, Cox C, Austin MT. Pediatric tracheobronchial injury after blunt trauma. J Trauma Acute Care Surg 2017:83(3):554-6.

[24] Suh JW, Shin HJ, Lee CY, Song SH, Narm KS, Lee JG. Surgical Repair of a Traumatic Tracheobronchial Injury in a Pediatric Patient Assisted with Venoarterial Extracorporeal Membrane Oxygenation. Korean J Thorac Cardiovasc Surg 2017:50(5):403-6 Oct.

[25] Noh D, Lee C, Hwang JJ, Cho HM. Concomitant Avulsion Injury of the Subclavian Vessels and the Main Bronchus Caused by Blunt Trauma. Korean J Thorac Cardiovasc Surg 2018;51(2):153-5 Apr. 


\section{STUDY}




\title{
A túlfújt endotrachealis mandzsetta szerepe a légcsősérülések diagnosztikájában
}

\author{
Rieth Anna dr. ${ }^{1}$ - Ottlakán Aurél dr. ${ }^{3}$ - Kovács Tamás dr. ${ }^{1}$ \\ Balogh Brigitta dr. ${ }^{1}$ - Furák József dr. ${ }^{2}$ \\ 'Szegedi Tudományegyetem, Általános Orvostudományi Kar, Gyermekklinika, Gyermeksebészet, Szeged \\ ${ }^{2}$ Szegedi Tudományegyetem, Általános Orvostudományi Kar, Sebészeti Klinika, Mellkassebészet, Szeged \\ ${ }^{3}$ Szegedi Tudományegyetem, Általános Orvostudományi Kar, Sebészeti Klinika, Szeged
}

\begin{abstract}
A tracheobronchialis sérülések ritkák, de életveszélyes állapotot jelenthetnek. Leggyakoribb okaik a nyaki vagy mellkasi, nagy energiájú tompa trauma, a nehéz intubálás vagy az intratrachealis tubus és gyomorszonda együttes viselése. A korai diagnózis és a megfelelő kezelés életmentő lehet, e sérülések felismerése azonban az atípusos tünetek és a súlyos társsérülések miatt gyakran elhúzódik. Típusos esetekben a fizikális vizsgálat során progresszív, kiterjedt subcutan emphysema hívhatja fel rájuk a figyelmet. További nehézséget jelent, hogy a radiológiai jelek nem elég specifikusak, a komputertomográfís felvételeken pedig a leggyakrabban csupán subcutan emphysema, pneumomediastinum vagy esetenként pneumothorax látható. Cikkünkben három eset kapcsán mutatjuk be a tracheobronchialis sérüléseket - egy baleseti, egy nehéz intubációs légúti sérülés, illetve egy tracheooesophagealis fistula kialakulása során. Az endotrachealis tubus ballonja a tracheafal rupturája mentén mindegyik esetben túlfújhatóvá vált, így a légút falán kívülre terjedt - ez a képalkotó vizsgálatokon láthatóvá is vált. Ez egy ritka, de direkt és egyértelmú jele a légúti sérüléseknek, mely alapján a trachea teljes falvastagságának szakadására lehet számítani. Cikkünkben a túlfújt ballon diagnosztikus jelentőségére szeretnénk rávilágítani.
\end{abstract}

Orv Hetil. 2020; 161(25): 1063-1068.

Kulcsszavak: túlfújt ballon, endotrachealis ballon, tracheasérülés, légúti sérülés

\section{The role of an overinflated endotracheal tube in the diagnosis of tracheal injuries}

Tracheobronchial injury is an uncommon, but often life-threatening condition. It is mostly caused by blunt thoracic or neck trauma, difficult or prolonged intubation associated with nasogastric tube insertion. An early diagnosis and treatment can be lifesaver. The diagnosis is often late because of atypical symptoms and unspecific radiological signs, and due to the presence of severe coexistent injuries. Generally, the classic hallmark during physical examination is a progressive, extensive surgical emphysema. Radiological signs are often atypical, which makes the diagnosis more difficult. The most frequent signs found on computed tomography are also unspecific, mostly surgical emphysema, pneumomediastinum or pneumothorax may be noted. We present three patients suffering from airway laceration caused by car accident, difficult intubation, and prolonged utilization of nasogastric and endotracheal tube. All the patients had an overdistended endotracheal balloon herniated outside the extratracheal space along the rupture of the tracheal wall. These external balloons were all detected on radiography. This is a direct and pathognomic sign of airway injury, suggesting complete rupture in the tracheal wall. In our report, we would like to highlight the diagnostic role of an overinflated cuff.

Keywords: overinflated cuff, endotracheal cuff, endotracheal balloon, tracheal lesion, airway injury

Rieth A, Ottlakán A, Kovács T, Balogh B, Furák J. [The role of an overinflated endotracheal tube in the diagnosis of tracheal injuries]. Orv Hetil. 2020; 161(25): 1063-1068.

(Beérkezett: 2020. január 30.; elfogadva: 2020. február 29.) 


\section{Rövidítések}

ATLS = (Advanced Trauma Life Support) a súlyos sérültek primer ellátásának protokollja; $\mathrm{CT}=$ (computed tomography $)$ számítógépes tomográfia; $\mathrm{ECMO}=($ extracorporeal membrane oxygenation) extracorporalis membránoxigenizáció; eFAST = (Extended Focused Assessment with Sonography in Trauma) fókuszált kiterjesztett traumatológiai ultrahangvizsgálat; ETT $=$ endotrachealis tubus; GCS $=($ Glasgow Coma Scale $)$ Glasgow Kóma Skála; MDCT = (multi-slice detector computed tomography) többszeletes detektoros számítógépes tomográfia; RSI $=$ (rapid sequence intubation $)$ gyors szekvenciális intubálás; $\mathrm{TEF}=($ tracheoesophageal fistula $)$ tracheooesophagealis fistula

A légút sérülésének számos oka lehet. A trauma miatt kialakuló ruptura tompa mellkasi vagy nyaki sérüléshez köthető, ez a legtöbbször autóbaleset, motorbaleset vagy magasból leesés következménye. Az érintettek többsége a helyszínen életét veszti (30-80\%) [1]. A kialakult inkomplett tracheasérülést az intubáció súlyosbíthatja, ezzel a légút falának teljes szeparációját okozhatja. Traumától függetlenül, egy nehéz intubációs helyzet önmagában is légúti sérüléshez vezethet, ekkor a tubus vége vagy a hirtelen, nagy nyomással felfújt ballon okozza a trachea laesióját [2]. Továbbá az endotrachealis tubus (ETT) és a nasogastricus szonda hosszan tartó használata tracheooesophagealis fistula (TEF) kialakulását okozhatja. Mindhárom fentebb leírt esetben az endotrachealis mandzsetta (cuff) a ruptura mentén túlfújódhat, és a légút falán kívülre herniálódhat. Radiológiai vizsgálatokkal ez a túlfújt ballon már korán észlelhető.

Általánosságban elmondható, hogy a tracheobronchialis sérülések esetén a gyors diagnózis életmentő lehet, de az atípusos tünetek és az indirekt radiológiai jelek megnehezítik a klinikus munkáját [1]. Ezért fontos a röntgen-, illetve CT-felvételeken látható hiperinflált ETT-ballon, a trachea falán kívül elhelyezkedő cuff, mivel ezek egyértelmű jelei a légúti sérülésnek.

\section{Esetbemutatás}

\section{Elsö eset}

Egy 9 éves fiú sérült autóbalesetben. A hátsó ülésen bekötve utazott, amikor kisodródtak, és egy fának ütköztek. A helyszínen újraélesztették, és RSI (rapid sequence intubation) szerint intubálták. A primer ellátás során láthatóvá vált a nyakon harántul lefutó contusio, amelyet egyértelműen a biztonsági öv lenyomata képezett. Az elkészült CT-vizsgálaton a nyaktól a mellkasfalon át a hasfalig húzódóan súlyos subcutan emphysema vált láthatóvá. Az ETT ballonja a légút várható méreténél nagyobbra, 2,56 cm-re volt felfújva, míg a trachea átmérője 1,03 cm volt, ezek alapján felmerült a tracheasérülés gyanúja (1. és 2. ábra). Fül-orr-gégész a ballontól mind caudalisan, mind cranialisan kizárta a laesio lehetőségét, a ballon szintjéról azonban nem tudott biztonsággal nyilatkozni, mert a légútvesztés veszélye miatt a beteget

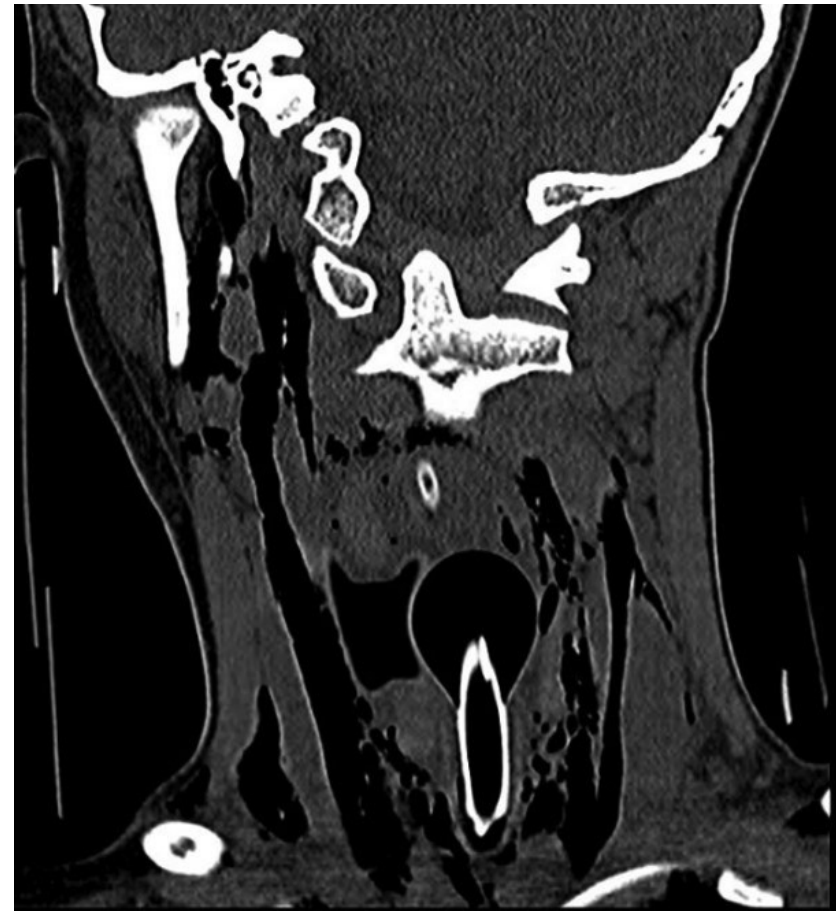

1. ábra Az első beteg CT-vizsgálata során látható a túlfújt ballon és a nyaki lágyrész-emphysema

CT = számítógépes tomográfia

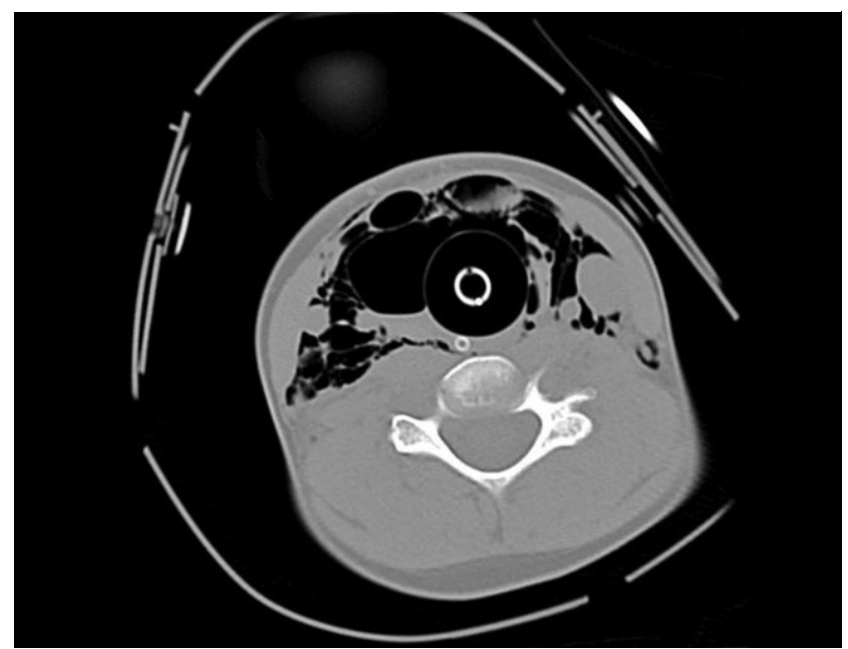

2. ábra Lágyrész-emphysema a túlfújt ballon szintjében, a trachea fala
nem azonosítható a CT-felvételen az első betegnél
CT = számítógépes tomográfia

még rövid időre sem lehetett extubálni. Sürgős mútét során láthatóvá vált a túlfújt ballon, melynek a szintjében a trachea folytonossága megszakadt, a distalis rész $3 \mathrm{~cm}$ rel caudalisabban folytatódott (3. ábra). Ezek alapján valószínúsíthetó, hogy a baleset következtében szakadt szét a trachea, és a két vég szétcsúszása adott helyet a túlfújt cuffnak. A sérülést primeren, feszülésmentes megszakított csomókkal zártuk. A további feszülésmentesség érdekében 3 napig nyaki flexiót alkalmaztunk. Preventív tracheostomia képzése történt. A posztoperatív szakban 

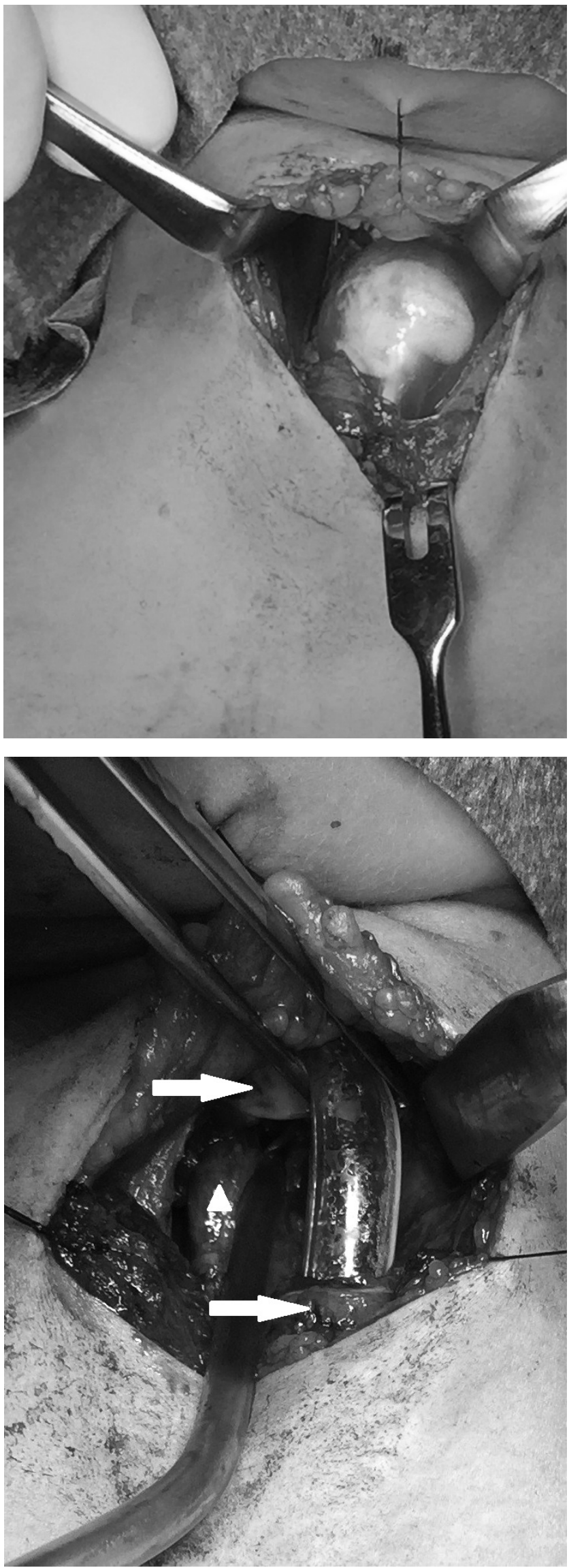

3. ábra

Intraoperatív képek az első betegnél. A nyilak jelölik a két tracheavéget, a háromszög a nyelőcsövet antibiotikumterápia indult, mediastinitis nem fejlődött ki. A mútétet követő 11. napon a gyermeket extubálták, további egy hét múlva a tracheakanült eltávolították, sérüléseiből maradéktalanul felépült.

\section{Második eset}

Egy 31 éves nőbeteget szállítottak a sürgősségi osztályra, aki autójával árokba hajtott. A biztonsági öv nem volt bekötve, a légzsák nem nyílt ki. A helyszínen eszméletlenül (GCS 2-4-1) találták, RSI szerint intubálták. Az elkészült sürgősségi CT alapján a C. I. csigolyán darabos törés volt látható. A nyakon kiterjedt subcutan emphysemát írtak le, amely a mediastinumba, majd a hasfali régióra is ráterjedt. A tubus cuffja $3,24 \mathrm{~cm}$ átmérôjü volt, míg a tubustól distalisan a trachea átmérője $1,53 \mathrm{~cm}$. A cuff túlfújt állapotban, a trachea hátulsó falán kívülre ért (4. és 5. ábra). Fül-orr-gégészeti bronchoszkópos vizsgálat lokalizálta a trachea pars membranacea sérülését. Sürgős mútét során $6 \mathrm{~cm}$ hosszú repedést találtunk a légcső hátulsó falán; a tubus cuffja a sérülés szintjében, de extratrachealisan, a légcső és a nyelőcső között helyezkedett el, disszekálva ezeket egymástól. A légcső sérülését primeren, feszülésmentes, megszakított öltésekkel zártuk. Preventív tracheostomia képzése történt. A posztoperatív szakban antibiotikumterápia indult, mediastinitis, illetve stenosis nem alakult ki.

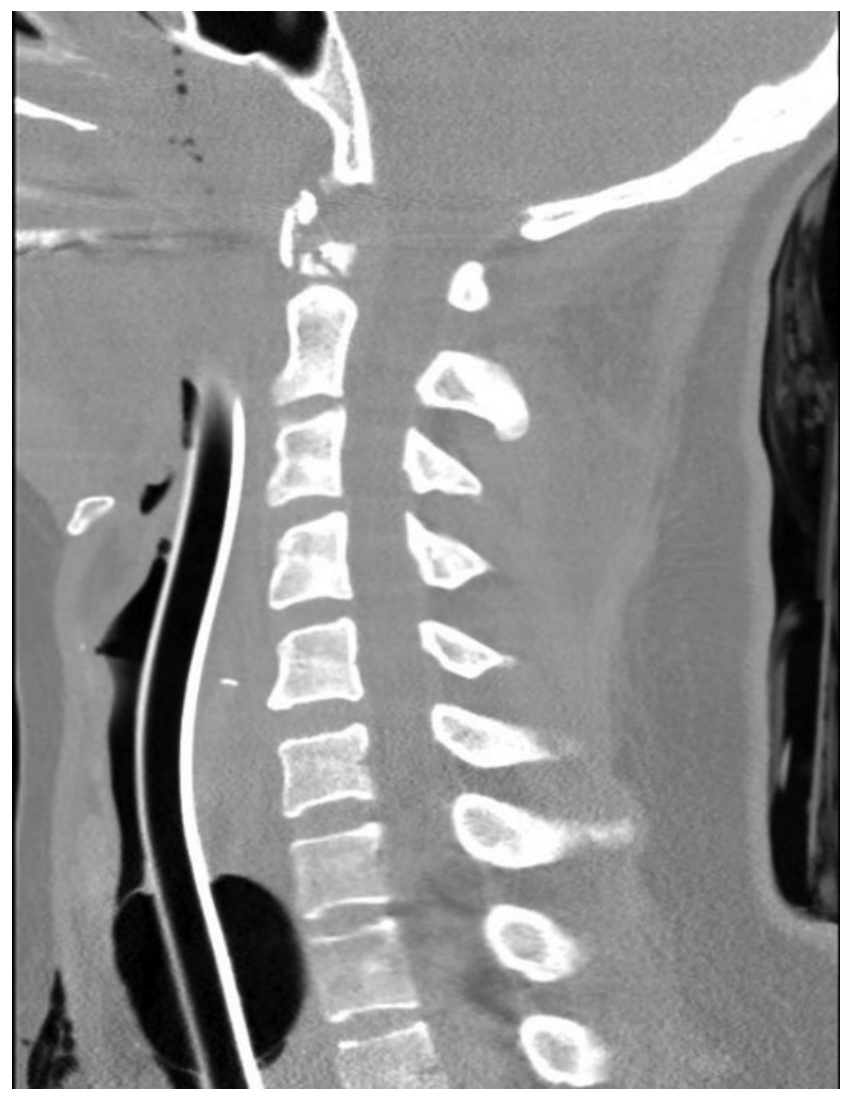

\begin{tabular}{l|l} 
4. ábra & Hátrafelé herniálódott cuff, ami a pars membranacea sérülésére
\end{tabular} utal a második esetben 


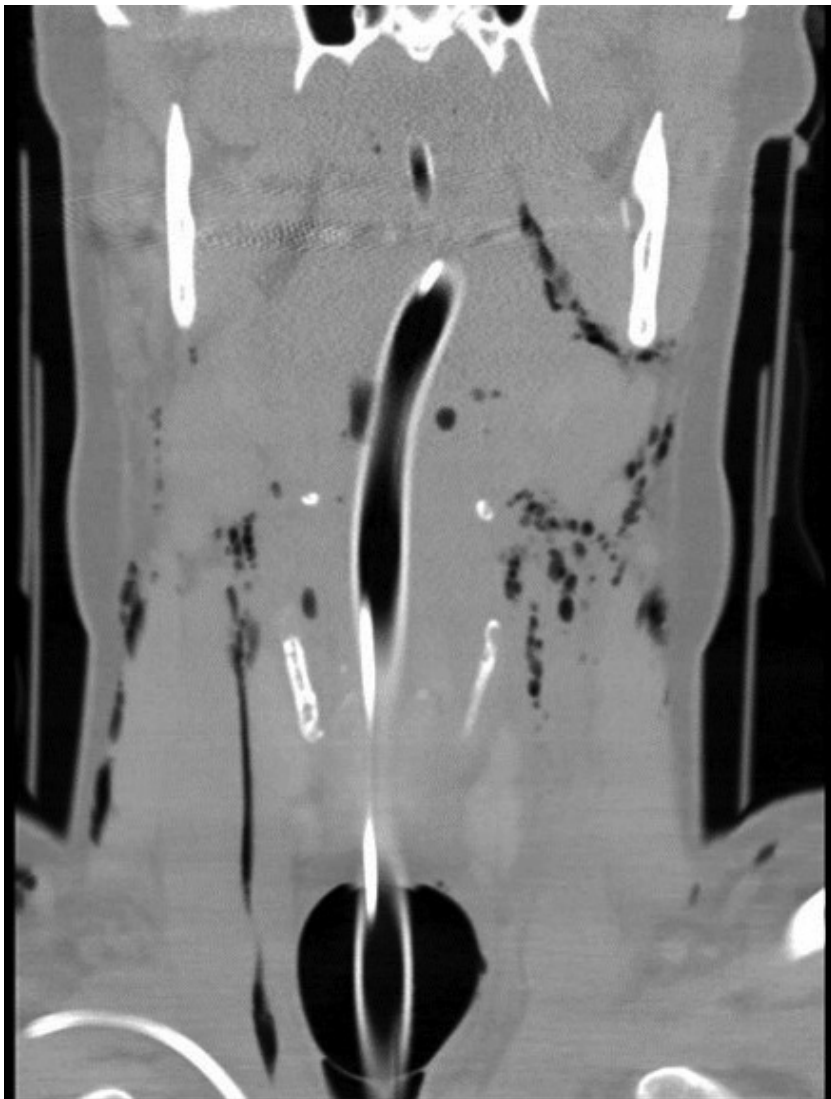

5. ábra

\section{Harmadik eset}

Egy 76 éves nőbetegnél intubálást és nasogastricus szondát alkalmaztak hosszabb időn keresztül, aminek során TEF alakult ki. A képalkotó vizsgálatokon jól látható a túlfújt ballon. A mellkasröntgen-felvételen 3,5 cm átmérőjü hiperinflált ballon volt látható (6. ábra). A CT-felvételen a trachea $1,5 \mathrm{~cm}$-es szakaszán nem tudták azonosítani a falát, mellette pneumomediastinumot diagnosztizáltak. A CT-felvétel mutatta a közös üreget, amely egybenyílva biztosította a teret a túlfújt ballonnak. Nyaki feltárásból a trachea primer suturája történt. Posztoperatíven antibiotikum indult, mediastinitis nem fejlődött ki.

\section{Megbeszélés}

A légúti sérüléseknek számos oka lehet; a leggyakrabban iatrogén úton vagy trauma kapcsán jönnek létre, a trachea cervicalis szakasza ilyen szempontból rendkívül sérülékeny. Trauma során a betegek többsége tompa mellkasi vagy nyaki sérülést szenved, jellemző mechanizmus a direkt erőbehatás vagy a hirtelen hiperextenzió. Tipikus sérülési mechanizmus, amikor a légcső direkt erő hatására a nyelőcsőhöz és a csigolyákhoz préselődik. Ilyen sérülést okozhat például a magasan húzódó biztonsági öv, ahogyan azt első betegünknél tapasztaltuk.

Nehéz intubálás közben szintén létrejöhet tracheobronchialis sérülés. A leggyakrabban RSI során a tubus

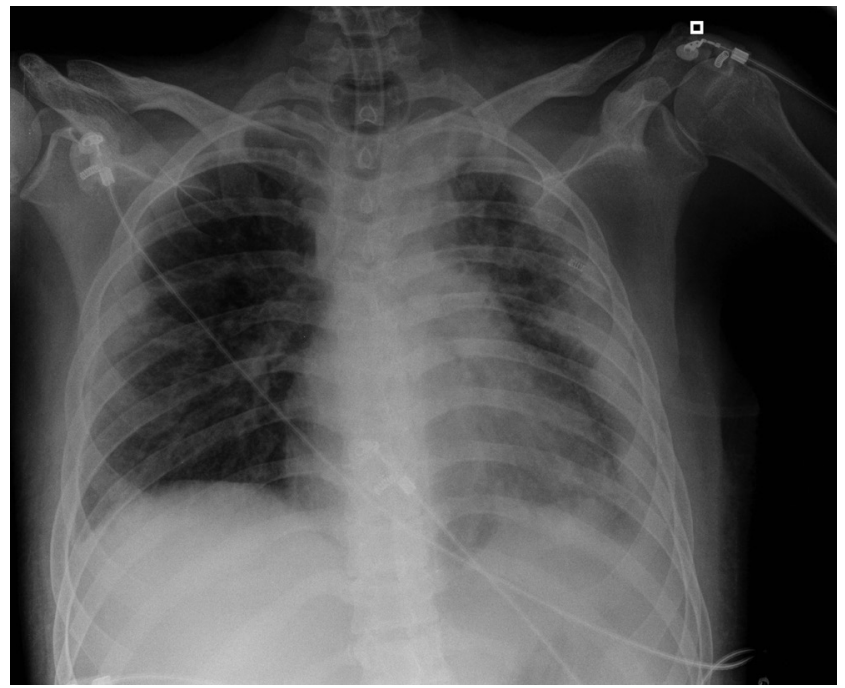

6. ábra

Röntgenfelvételen látható túlfújt ballon a harmadik esetben

vége vagy a hirtelen, túlzottan felfújt cuff okozhatja a rupturát. Hajlamosító tényező a többszöri intubációs kísérlet, a tubus újrapozicionálása a mandzsetta nem megfelelő deflációjával, köhögés, nagy méretű tubus, nem megfelelően alkalmazott vezetőnyárs, illetve a fej vagy a nyak hirtelen mozgatása [2]. A laesio döntően a hátulsó hártyás falon alakul ki, ahol a $\mathrm{C}$ alakú porcok védőhatása már nem érvényesül. Nőknél szignifikánsan gyakoribb a sürgősségi intubáció utáni légcsősérülés, ami a gyengébb hátulsó fal és az eltérő anatómia miatt lehetséges (például relatíve rövidebb trachea) [3]. A trauma miatt kialakult sérülés szintjében az intubálás során felfújt ETT-ballon a laesiót súlyosbíthatja, a ballon átrepesztheti a trachea falát, és túlfúvódik a légúton kívülre.

Meg kell említeni a hosszan tartó intubációs időt is, ami TEF létrejöttéhez vezethet. A több mint 12 napig (12 és 200 nap között, átlag 40 napig) tartó intubáció, fóként nasogastricus szondával együtt, TEF kialakulására hajlamosít. Számos hajlamosító tényezőt ismerünk, ilyen többek között a tubus elmozdulása, infekció, szteroid, hipotenzió, időskor, diabetes. A TEF kialakulásának egyik legjelentősebb oka azonban a nagy nyomású ETTballon, amely a trachea falát a szondához nyomja. Ezen a helyen ischaemia, necrosis, majd fistula alakul ki [4]. Mind a traumás betegek intubálásakor, mind a hosszan tartó intubációs esetekben a mandzsetta hiperinflációja nyomásméréssel megelőzhető lehet. Az ajánlott érték 20 és $30 \mathrm{H}_{2} \mathrm{Ocm}$ között van; az ennél magasabb nyomás a kapilláris keringést gátolja, ezzel ischaemiát okozhat [5]. Az ellenőrző ballon tapintása nem elégséges a cuff nyomásának ellenőrzésére, mivel az esetek nagy részében a helyszíni intubációk során túl magas nyomással kerül felfúvásra $[6,7]$. A fentiek miatt fontos a mentőszemélyzet felkészítése a posztintubációs szövődményekre és főként azok megelőzésére. Az intubáció során a megfelelően kiválasztott tubusméret, a cuffnyomás mérése, a cuff leengedése a tubus mozgatása előtt, illetve a túlzott erőbevi- 
tel és a hirtelen manőverek kerülése a légcsősérülés veszélyét csökkenthetik.

A tracheobronchialis sérülések diagnosztikája sokszor nehézségekbe ütközik az atípusos tünetek és radiológiai jelek miatt. A fizikális vizsgálat során a leggyakrabban nehézlégzés, haemoptysis látható. A stridor vagy rekedtség a tracheát érintő sérülés korai jelei lehetnek. A fent említett tünetek azonban nem elég specifikusak a betegségre nézve. Emellett a társuló súlyos, akár életveszélyes sérülések elfedhetik a tüneteket. Cervicalis trauma során a leggyakrabban a nyelőcső, a nyaki nagyerek, a nervus laryngeus recurrens, a nyaki csigolyák, illetve a gége sérülésére számíthatunk.

A fizikális vizsgálat során a tracheobronchialis sérülések klasszikus jele a progresszív subcutan emphysema, amely a hasfalra, akár a végtagokra is ráterjedhet. Fokozatosan szélesedő, extrém kiterjedt subcutan emphysema esetén a légúti sérülés lehetősége mindig fel kell, hogy merüljön. Ám nem minden esetben van jelen emphysema. A környező lágyrészek még teljes légcsőruptura esetén is fedhetik a csonkot, megakadályozva ezzel a levegőnek a szövetekbe terjedését. A fistulára nem jellemző az emphysema, ezért TEF során aspiráció vagy a gyomor indokolatlan disztenziója lehet az első tünet.

Általánosságban elmondható, hogy képalkotók segítségével a légcsősérülés direkt vizualizációja csak ritkán lehetséges, indirekt jelekből azonban lehet rá következtetni. Az Advanced Trauma Life Support (ATLS) legfrissebb, 10. kiadásában a primer ellátás részét képezi az eFAST- (Extended Focused Assessment with Sonography in Trauma) vizsgálat [8]. E szerint a mellkas ultrahangvizsgálata során a klinikus képes kimutatni a légmell jelenlétét. Bár a subcutan emphysema korlátozhatja a vizsgálatot, ezekben az esetekben utalhat is a légút sérülésére. Nyaki és mellkas-röntgenfelvételeken a legtöbbször súlyos lágyrész-emphysema, pneumomediastinum, esetenként pneumothorax látható. A nyaki, illetve mellkasi MDCT- (multi-slice detector computed tomography) felvétel a leginformatívabb radiológiai vizsgálat, ám itt is szintén ezek a jelek (emphysema, pneumomediastinum, pneumothorax) dominálnak. Esetleg a trachealis légsáv elmosódása, megszakadása vagy paratrachealis légsáv jelenhet meg. Mindezek alapján a negatív CT nem zárja ki a légcsősérülés lehetőségét [9-11]. Segítségünkre lehet a háromdimenziós rekonstrukció vagy a virtuális bronchoszkópia is a diagnózisban. Amennyiben a nyelőcsősérülés lehetősége is felmerül, kontrasztanyagos oesophagographia elvégzése igazolhatja a trachea hátsó falának rupturáját.

A fentiek mellett azonban a légúti sérülések diagnosztikájában a fiberoszkópos vizsgálat az „arany standard” eljárás [9]. Számos előnye van a CT-vizsgálattal szemben: gyors, egyszerú, és pontosabb képet adhat a sérülés helyéről, kiterjedéséről. Amennyiben a ruptura helye az endotrachealis ballon szintjében helyezkedik el, elképzelhető, hogy a fiberoszkópos vizsgálat nem látja a laesiót.
Ezek alapján látható, hogy a gondos kivizsgálás ellenére is nehéz a diagnózis felállítása, és az gyakran indirekt radiológiai jeleken és tüneteken alapul. Cikkünkben szeretnénk rávilágítani a légúti sérülés mentén túlfújt ETTmandzsetta jelentőségére, ami pathognomicus jelnek számít, és akár röntgenfelvételen is mutathatja a légcsősérülés jelenlétét. A túlfújt ballon egy ritka, de egyértelmú jele a trachea laesiójának, ennek láttán számíthatunk arra, hogy a légcső teljes falvastagsága átrepedt a ballon szintjében [12-15]. Első betegünknél a trachea teljes szeparációja jött létre, míg a második esetben a hátrafelé herniálódó ballon a pars membranaceán keletkezett hosszanti repedés jele volt. TEF esetén a mediastinalis vagy subcutan emphysema megjelenése nem típusos, de a túlfújt ballon utalhat a diagnózisra. Ilyenkor a ballon a nyelő́csőbe nyomul be. A szakirodalomban említést tesznek arról, hogy a részben herniálódott ballon alakja deformálódhat, gömb helyett például homokóra vagy úgynevezett Miki egér-formát vesz fel, ahogyan második betegünknél is ezt láttuk [13].

Nem típusos esetekben a túlfújt ballon képe alapján merülhet fel a tracheobronchialis sérülés lehetősége, ennek alapján végezhetünk célzott bronchoszkópos vizsgálatot. Első betegünknél a fiberoszkópia megállapította ugyan, hogy a ballontól caudalisan, illetve cranialisan nem látható laesio, de nem segített hozzá a pontos diagnózishoz, és a további ellátás szempontjából irreleváns volt. A második betegnél, bár lokalizálta a sérülést, de a CT-felvételt áttekintve a trachea rupturája már a képalkotó alapján is jól látható volt. A felvételeken észlelt extratrachealis ballon miatt tehát a betegség láthatóvá vált, ráadásul mindkét esetben pontosan mutatta a laesio helyét is.

Mútét során a laesio helyétől függetlenül a primer rekonstrukció ajánlott. Nagyobb vagy teljes ruptura esetén a szélek reszekciója elkerülhetetlenné válhat, törekedni kell azonban a lehető legkisebb kimetszésre, fóként a carina közelében $[16,17]$. Kiterjedt sérülés esetén tracheostomia is szóba jöhet. Fontos az anastomosis feszülésmentes zárása, ha szükséges, a nyak néhány napos flexióban tartása tehermentesítheti a varratokat. Súlyos légúti sérülés kapcsán egy protektív réteget (pleura, pericardium, izomlebeny) helyezhetünk az anastomosis fölé, ezzel szeparálva a nyelőcsövet [17]. Kisebb TEF esetén sutura, kiterjedt fistula ellátásakor tracheareszekció és izomlebeny használata válhat szükségessé.

Néhány kivételes esetben a sebészeti megoldás mellett a konzervatív kezelés is elfogadott lehetőség. Bár nincs egységes protokoll erre nézve, a szakirodalom alapján ennek ajánlott kritériumai a következő́k lehetnek: a laesio kisebb, mint $2 \mathrm{~cm}$, vagy egyharmada a légcső átmérójének; a beteg klinikailag stabil; spontán lélegzik, vagy minimális légzéstámogatást igényel; nincs jele mediastinitisnek vagy szepszisnek; nincs súlyos társsérülés [1, 16, 17]. Dönthetünk a konzervatív és a sebészeti kezelés között annak alapján is, hogy a falvastagság mekkora részét érinti a sérülés. Cardillo és mtsai cikkükben kategorizál- 
ják és leírják a iatrogén tracheasérülések kezelési tervét: inkomplett sérülés vagy egyszerú komplett ruptura esetén konzervatív kezelés lehetséges. Komplett sérülés mediastinitisszel vagy a nyelőcső sérülésével társulva, illetve a trachea teljes szeparációjával járó sérülés esetén sebészeti kezelés ajánlott [18].

Konzervatív kezelés fooként iatrogén esetekben javasolt. Ajánlott antibiotikumterápia indítása, az ETT-ballonnak a sérüléstől distalisan történő pozicionálása, illetve a drenálás is megfontolandó. Azoknak a betegeknek, akik számára a mútét túl kockázatos, alternatív kezelési módszer lehet sztent behelyezése. Ez a technika elsősorban szintén iatrogén esetekben ajánlott, illetve jó eredményeket értek el a légcsősérülések következményeként kialakuló szükületek kezelésében [19]. Instabil, kritikus állapotú betegekkel kapcsolatban az elmúlt években egyre nagyobb számban publikálnak jó tapasztalatokat ECMO- (extracorporeal membrane oxygenation) kezeléssel [20].

\section{Következtetések}

Elmondható, hogy tompa mellkasi vagy nyaki trauma és nehéz intubáció során a légcső sérülésére gondolnunk kell, fóként, ha kiterjedt subcutan emphysema is jelen van. Hosszabb ideje tartó intubáció mellett szintén számolnunk kell a tracheasérülés lehetőségével. A diagnosztikus folyamat során gyakran az egyetlen egyértelmú jel a CT-n vagy röntgenen látható, túlfújt tubusmandzsetta, mely mutatja a légcső rupturáját, és így korai célzott fiberoszkópos vizsgálat végezhető.

Anyagi támogatás: A cikk elkészítése anyagi támogatásban nem részesült.

Szerzôi munkamegosztás: R. A: A közlemény megírása. O. A., B. B.: Adatgyújtés. K. T.: Szakirodalmi kutatás. F. J.: Az operációk elvégzése, a kézirat áttekintése, a szöveg szakmai véleményezése. A cikk végleges változatát valamennyi szerző elolvasta és jóváhagyta.

Érdekeltségek: A szerzőknek nincsenek érdekeltségeik.

\section{Irodalom}

[1] Linegar A, Schulenburg R. Tracheobronchial trauma. In Kużdżał J, Asamura H, Detterbeck FC, et al. (eds.) ESTS textbook of thoracic surgery. Vol 2. Medycyna Praktyczna, Cracow, 2015; pp. 937-943.

[2] Baranyai Zs, Kocsis Á, Jósa V. Successful surgical treatment of tracheal rupture caused by endotracheal intubation. [Endotra- chealis intubáció okozta trachearuptura sikeres sebészi ellátása.] Orv Hetil. 2010; 151: 946-949. [Hungarian]

[3] Fan CM, Ko PC, Tsai KC, et al. Tracheal rupture complicating emergent endotracheal intubation. Am J Emerg Med. 2004; 22: 289-293.

[4] Kaur D, Anand S, Sharma P, et al. Early presentation of postintubation tracheoesophageal fistula: perioperative anesthetic management. J Anaesthesiol Clin Pharmacol. 2012; 28: 114-116.

[5] Talekar CR, Udy AA, Boots RJ, et al. Tracheal cuff pressure monitoring in the ICU: a literature review and survey of current practice in Queensland. Anaesth Intensive Care 2014; 42: 761770.

[6] Peters JH, Hoogerwerf N. Prehospital endotracheal intubation; need for routine cuff pressure measurement? Emerg Med J. 2013; 30: 851-853.

[7] Rahmani F, Soleimanpour H, Zeynali A, et al. Comparison of tracheal tube cuff pressure with two techniques: fixed volume versus pilot balloon palpation. J Cardiovasc Thorac Res. 2017; 9: 196-199

[8] Thoracic trauma. In: Merrick C. (ed.) ATLS Advanced Trauma Life Support, Student Course Manual. Tenth edition. American College of Surgeons, Chicago, IL, 2018; pp. 62-81.

[9] Bagga B, Kumar A, Chahal A, et al. Traumatic airway injuries: role of imaging. Curr Probl Diagn Radiol. 2020; 49: 48-53.

[10] Cheng J, Cooper M, Tracy E. Clinical considerations for blunt laryngotracheal trauma in children. J Pediatr Surg. 2017; 52: 874-880.

[11] Santiago-Rosado LM, Sigmon DF, Lewison CS. Tracheal trauma. [Updated 2020 March 18.] In: StatPearls [Internet]. Treasure Island (FL), StatPearls Publishing, 2020. Available from: http://www.ncbi.nlm.nih.gov/books/NBK500015/ [accessed: January 26, 2019].

[12] Euathrongchit J, Thoongsuwan N, Stern EJ. Nonvascular mediastinal trauma. Radiol Clin North Am. 2006; 44: 251-258.

[13] Chen JD, Shanmuganathan K, Mirvis SE, et al. Using CT to diagnose tracheal rupture. Am J Roentgenol. 2001; 176: 12731280.

[14] Rollins RJ, Tocino I. Early radiographic signs of tracheal rupture. Am J Roentgenol. 1987; 148: 695-698.

[15] Scaglione M, Romano S, Pinto, A et al. Acute tracheobronchial injuries: impact of imaging on diagnosis and management implications. Eur J Radiol. 2006; 59: 336-343.

[16] Altinok T, Can A. Management of tracheobronchial injuries. Eurasian J Med. 2014; 46: 209-215.

[17] Zhao Z, Zhang T, Yin X, et al. Update on the diagnosis and treatment of tracheal and bronchial injury. J Thorac Dis. 2017; 9: E50-E56.

[18] Cardillo G, Carbone L, Carleo F, et al. Tracheal lacerations after endotracheal intubation: a proposed morphological classification to guide non-surgical treatment. Eur J Cardiothorac Surg. 2010; 37: 581-587.

[19] Shemmeri E, Vallières E. Blunt tracheobronchial trauma. Thorac Surg Clin. 2018; 28: 429-434.

[20] Biancosino C, Krüger M, Kühn C, et al. First successful surgical reconstruction of bilateral transected main bronchi with extracorporeal membrane oxygenation support. Ann Thorac Surg. 2016; 102: el35-e137.

(Rieth Anna dr., Szeged, Korányi fasor 14-15., 6725 e-mail: rieth.anna@med.u-szeged.hu)

A cikk a Creative Commons Attribution 4.0 International License (https://creativecommons.org/licenses/by/4.0/) feltételei szerint publikált Open Access közlemény, melynek szellemében a cikk bármilyen médiumban szabadon felhasználható, megosztható és újraközölhető, feltéve, hogy az eredeti szerző és a közlés helye, illetve a CC License linkje és az esetlegesen végrehajtott módositások feltüntetésre kerülnek. (SID_1) 